\author{
Universidade de São Paulo \\ Instituto de Física
}

\title{
Sistemas Porosos de Zircônia e Céria
}

\author{
Rebeca Bacani
}

Orientadora: Prof $^{\mathrm{a}}$ Dr$^{\mathrm{a}}$ Márcia Carvalho de Abreu Fantini

Dissertação de mestrado apresentada ao Instituto de Física para a obtenção do título de Mestre em Ciências

Comissão examinadora:

Prof ${ }^{\mathrm{a}}$. Dra . Márcia Carvalho de Abreu Fantini (IF-USP)

Prof. Dr. Giancarlo Espósito de Souza Brito (IF-USP)

Prof. Dr. Renato Sanches Freire (IQ-USP)

São Paulo

2009 


\section{FICHA CATALOGRÁFICA}

Preparada pelo Serviço de Biblioteca e Informação do Instituto de Física da Universidade de São Paulo

Bacani, Rebeca

Sistemas Porosos de Zircônia e Céria - São Paulo, 2009

Dissertação (Mestrado) - Universidade de São Paulo. Instituto de Física - Depto. Física Aplicada.

Orientadora: Prof ${ }^{a}$ Dr $^{\mathrm{a}}$ Márcia Carvalho de Abreu Fantini Área de Concentração: Física da Matéria Condensada

Unitermos:

1. Física da Matéria Condensada;

2. Mesoporoso;

3. Zircônia;

4. Céria;

5. SAXS (Espalhamento de raios X a baixo ângulo). 


\section{Agradecimentos}

a Profa. Dra. Tereza. S. Martins da UNIFESP - Diadema.

a orientadora Profa. Dra. Márcia C. A. Fantini do Laboratório de Cristalografia do IF-USP.

ao Prof. Dr. Renato Freire e a todos do Laboratório do Grupo de Pesquisa em Química Verde e Ambiental (GPQVA) do IQ-USP.

ao Antônio Carlos, Serginho e a todos do Laboratório de Cristalografia do IF-USP.

ao Prof. Dr. Jivaldo R. Matos do Laboratório de Análise Térmica do IQ-USP.

ao Prof. Dr. Diego G. Lamas e ao Prof. Dr. Rodolfo O. Fuentes do CINSO, Argentina.

ao $\mathrm{CNPq}$ pelo apoio financeiro.

a FAPESP pela utilização de equipamentos.

ao LNLS pela utilização das facilidades experimentais.

ao Gabriel Weber do Departamento de Física Matemática do IF-USP.

ao Francisco M. Neto do Laboratório de Cristalografia do IF-USP.

e a todos amigos e familiares que ajudaram na conclusão desse trabalho. 



\section{Sumário}

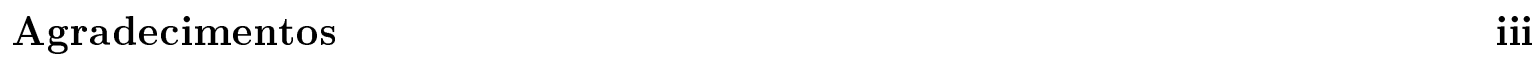

Resumo xi

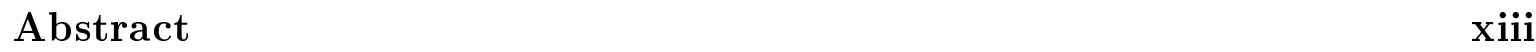

$\begin{array}{lll}1 & \text { Estado da arte } & 1\end{array}$

1.1 Materiais porosos e aplicações . . . . . . . . . . . . . . . . . . . . . . . 1

1.2 Motivação e objetivos . . . . . . . . . . . . . . . . 8

\begin{tabular}{|lll}
2 & Técnicas experimentais de análise & 11
\end{tabular}

$2.1 \quad$ Difração de raios X $(\mathrm{XRD})$. . . . . . . . . . . . . . . . . 11

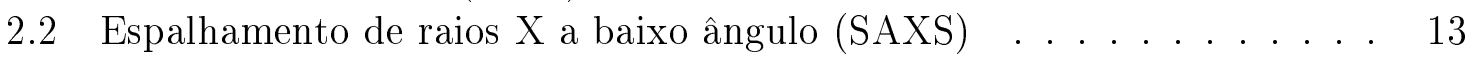

2.3 Isotermas de adsorção-dessorção de nitrogênio

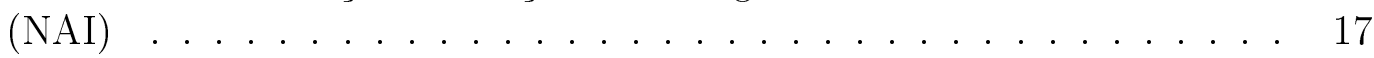

3 Síntese de $\mathrm{ZrO}_{2}-\mathrm{CeO}_{2}$ poroso: resultados e discussão 21

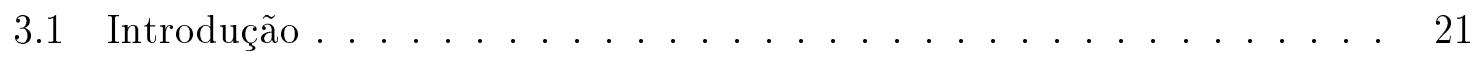

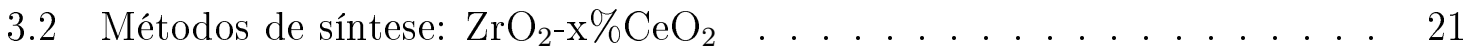

3.3 Resultados . . . . . . . . . . . . . . . . . . . . . . . 25

3.3 .1 Método cloreto hidratado . . . . . . . . . . . . 25

3.3 .2 Método cloreto anidro . . . . . . . . . . . . . 28

3.3 .3 Método nitrato . . . . . . . . . . . . . . . . 36

3.3 .4 Método solução supersaturada . . . . . . . . . . . . . . . 39

3.4 Sínteses com silício: Resultados . . . . . . . . . . . . . . . . . 42

3.4 .1 Método híbrido . . . . . . . . . . . . . . . . . . . . . . 43

$3.4 .2 \quad$ Método paliçada de $\mathrm{Si} \ldots \ldots . \ldots . \ldots 46$

3.4.3 Método paliçada de Si com temperatura de síntese de $40^{\circ} \mathrm{C}$. . . 53

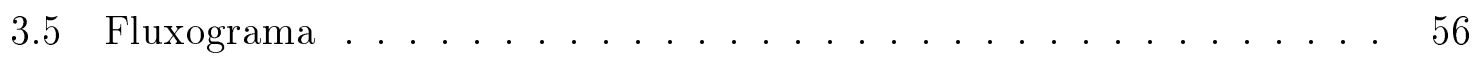

4 Comparação dos resultados e conclusões $\quad 57$ 
$\begin{array}{lll}5 & \text { Trabalhos Futuros } & 61\end{array}$

Referências $\quad 62$ 


\section{Lista de Figuras}

1.1 Estruturas de poros hexagonal, cúbica e lamelar da família M41S (L. C. Cides da Silva, IQ-USP. Dissertação de Mestrado, 2003). . . . . . . . . 2

1.2 Imagem de microscopia eletrônica de transmissão do MCM-41, no detalhe, o formato dos poros em estrutura bidimensional hexagonal[1]. . . 2

1.3 Representação do mecanismo de formação de auto-agregação na síntese com troca iônica|2. . . . . . . . . . . . . 4

1.4 Representação do mecanismo de formação de materiais mesoporosos com

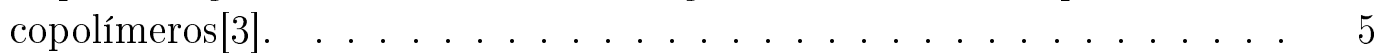

1.5 Resultados para a conversão de metano $\left(\mathrm{CH}_{4}\right)$ e dióxido de carbono $\left(\mathrm{CO}_{2}\right)$ com Ni disperso em matriz de zircônia mesoporosa em comparação a uma amostra convencional de zircônia com 10\% de Ni sintetizada por precipitação (Conv.)[35]. . . . . . . . . . . . . . . 6

1.6 Representação esquemática de funcionamento de uma célula combustível de óxido sólido (SOFC), (U.S.Dept. of Energy-EERE). . . . . . . . . . 6

1.7 Fases do óxido de zircônio[30]. . . . . . . . . . . . . 8

2.1 Representação da difração de raios X por um cristal. . . . . . . . . . 12

2.2 Montagem para um equipamento de SAXS[4]. . . . . . . . . . . . . 14

2.3 Intensidade espalhada para 3 esferas de raios diferentes, onde $\mathrm{x}=\mathrm{q}$ (vetor de espalhamento, $q=(4 \pi / \lambda) \operatorname{sen} \theta_{h k l}$ (A. F. Craievich, com permissão). . 14

2.4 Intensidade espalhada para um gás, líquido e um sólido organizado, onde $\epsilon=2 \theta$ (A. F. Craievich, com permissão). . . . . . . . . . 15

2.5 Esquema da estrutura de poros hexagonal bidimensional da sílica SBA-

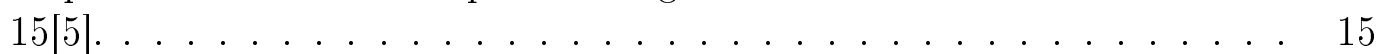

2.6 (a) Representação dos tipos de isotermas de adsorção descritos por Brunauer; (b) Representação dos tipos de histereses em isotermas de

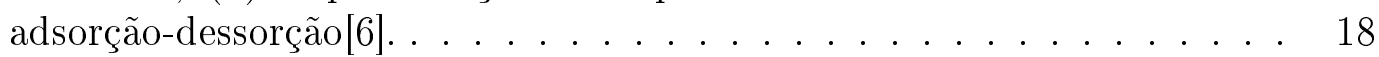

$3.1 \quad$ Diagrama esquemático de síntese de $\mathrm{ZrO}_{2}-\mathrm{CeO}_{2}$ porosa. . . . . . . . . . 22 
3.2 Resultados de SAXS para amostras como sintetizadas (AS), para o método cloreto hidratado com concentração molar de 50, 70 e $90 \%$ de

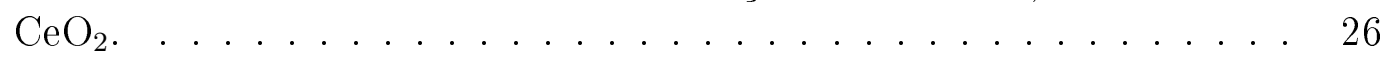

3.3 Resultados de SAXS para amostras como sintetizadas pelo método cloreto anidro para a concentração molar de 50 e $90 \%$ de $\mathrm{CeO}_{2}$ (LNLS). . . . . 28

3.4 Resultados do experimento de SAXS com calcinação in-situ para a amostra de $\mathrm{ZrO}_{2} / \mathrm{CeO}_{2}$ com $50 \%$ de $\mathrm{CeO}_{2}$ (LNLS). . . . . . . . . . . 30

3.5 Resultados do experimento de SAXS com calcinação in-situ para a amostra de $\mathrm{ZrO}_{2} / \mathrm{CeO}_{2}$ com $90 \%$ de $\mathrm{CeO}_{2}$ (LNLS). . . . . . . . . . 31

3.6 Resultados de XRD para a amostra de $\mathrm{ZrO}_{2} / \mathrm{CeO}_{2}$ com $50 \%$ de $\mathrm{CeO}_{2}$

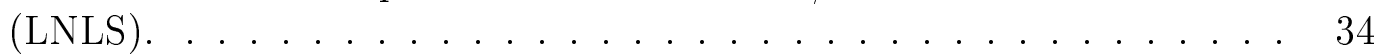

3.7 Resultados de XRD para a amostra de $\mathrm{ZrO}_{2} / \mathrm{CeO}_{2}$ com $90 \%$ de $\mathrm{CeO}_{2}$

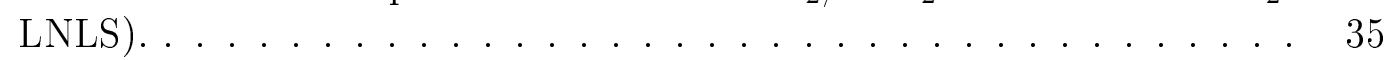

3.8 Resultados para as isotermas de adsorção-dessorção de $\mathrm{N}_{2}$ para as amostras com concentrações molares de $50 \%$ e $90 \%$ de $\mathrm{CeO}_{2}$ (método cloreto anidro). 36

3.9 Resultados de SAXS para amostra de $\mathrm{ZrO}_{2} / \mathrm{CeO}_{2}$ com $90 \%$ de $\mathrm{CeO}_{2}$

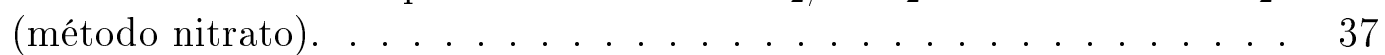

3.10 Resultados de XRD para amostra calcinada até $540^{\circ} \mathrm{C}$, de $\mathrm{ZrO}_{2} / \mathrm{CeO}_{2}$ com $90 \%$ de $\mathrm{CeO}_{2}$ (método nitrato). $\ldots \ldots \ldots . \ldots . \ldots 38$

3.11 Resultados para a isoterma de adsorção-dessorção de $\mathrm{N}_{2}$ para a amostra com concentração molar de $90 \%$ de $\mathrm{CeO}_{2}$ (método nitrato). . . . . . . . 39

3.12 Resultados de SAXS para amostra como sintetizada, com tratamento térmico até $300^{\circ} \mathrm{C}$ e calcinada até $540^{\circ} \mathrm{C}$, de $\mathrm{ZrO}_{2} / \mathrm{CeO}_{2}$ com $90 \%$ de $\mathrm{CeO}_{2}$ (método solução supersaturada). . . . . . . . . . . 40

3.13 Resultados de XRD para amostra, calcinada até $540^{\circ} \mathrm{C}$, de $\mathrm{ZrO}_{2} / \mathrm{CeO}_{2}$ com $90 \%$ de $\mathrm{CeO}_{2}$ (método solução supersaturada). . . . . . . . . . . 41

3.14 Diagrama esquemático das sínteses de $\mathrm{SiO}_{2}: \mathrm{ZrO}_{2}-\mathrm{CeO}_{2}$ poroso. . . . . . 43

3.15 Resultados de SAXS para a amostra como sintetizada e calcinada (até

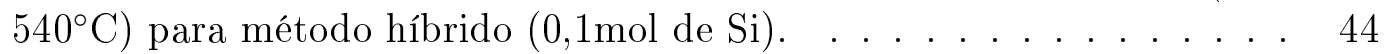

3.16 Resultados para a isoterma de adsorção-dessorção de $\mathrm{N}_{2}$ para a amostra

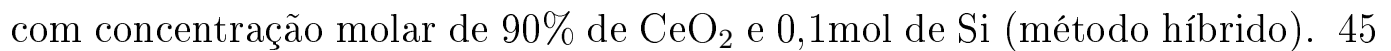

3.17 Resultados de SAXS para amostra como sintetizada e calcinada (até $540^{\circ} \mathrm{C}$ ) para amostra de $\mathrm{ZrO}_{2} / \mathrm{CeO}_{2}$ com $90 \%$ de $\mathrm{CeO}_{2}$ e $0,1 \mathrm{~mol}$ de $\mathrm{Si}$

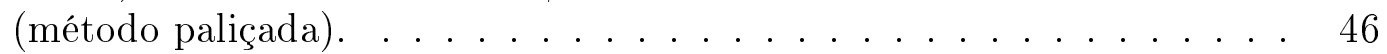

3.18 Resultados de SAXS para a amostra como sintetizada e calcinada (até $540^{\circ} \mathrm{C}$ ) para amostra de $\mathrm{ZrO}_{2} / \mathrm{CeO}_{2}$ com $90 \%$ de $\mathrm{CeO}_{2}$ e $0,3 \mathrm{~mol}$ de $\mathrm{Si}$

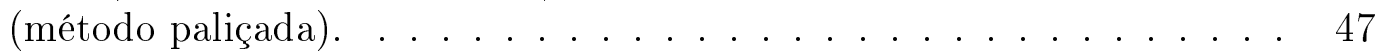

3.19 Resultados de SAXS e XRD para tratamento térmico a 300, 350, 400 e calcinação até $540^{\circ} \mathrm{C}$ da amostra Zr90CeP10, sintetizada através do método paliçada, com $90 \%$ de Ce e $10 \%$ de Si. . . . . . . . . . . . . 49 
3.20 Resultados de SAXS e XRD para tratamento térmico a 300, 350, 400 e calcinação até $540^{\circ} \mathrm{C}$ da amostra Zr90CeP30, sintetizada através do método paliçada, com 90\% de Ce e 30\% de Si. . . . . . . . . . . 50

3.21 Resultados para as isotermas de adsorção-dessorção de $\mathrm{N}_{2}$ para as amostras com concentração molar de $90 \%$ de $\mathrm{CeO}_{2}, 0,3$ e 0,1mol de Si (método

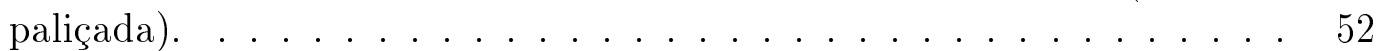

3.22 Resultados de SAXS para tratamento térmico a $400^{\circ} \mathrm{C}$ e calcinação até $540^{\circ} \mathrm{C}$ para o método paliçada temperatura de síntese de $40^{\circ} \mathrm{C}$, com $90 \%$ de $\mathrm{Ce}$ e $30 \%$ de Si. . . . . . . . . . . . . . . 53

3.23 Resultados de XRD para amostra calcinada até $540^{\circ} \mathrm{C}$, de $\mathrm{ZrO}_{2} / \mathrm{CeO}_{2}$ com $90 \%$ de $\mathrm{CeO}_{2}$ (método paliçada com temperatura de síntese de $40^{\circ} \mathrm{C}$ ). 54

3.24 Fluxograma com estratégias de síntese, tratamentos térmicos e calcinações feitas nesse trabalho. . . . . . . . . . . . . . 56 



\section{Resumo}

Neste trabalho foram desenvolvidas sínteses de $\mathrm{ZrO}_{2}-\mathrm{x} \% \mathrm{CeO}_{2}$, baseadas na preparação da sílica mesoporosa ordenada SBA-15, utilizando um molde de co-polímero tribloco Pluronic P-123, diversos precursores de zircônio e cério e diferentes métodos. Os métodos de síntese testados foram com: precursores a base de cloreto hidratado $(\operatorname{com} \mathrm{x}=50,70$ e 90$)$, precursores a base de cloreto anidro $(\mathrm{x}=50$ e 90$)$, precursores a base de nitrato $(x=90)$, solução supersaturada de nitrato $(x=90)$, do tipo híbrido com Zr, Ce e Si (com 10\%mol de Si e x=90), paliçada de Si (com 10 e 30\%mol de $\mathrm{Si} \mathrm{e} \mathrm{x}=90)$ e paliçada de $\mathrm{Si}$ com temperatura de síntese de $40^{\circ} \mathrm{C}(\mathrm{com} 30 \% \mathrm{~mol}$ de $\mathrm{Si}$ e $\mathrm{x}=90$ ). Visando obter paredes compostas por fase cristalina única e grande área superficial, para futuras aplicações em catálise. Os compósitos polímero/(zircôniocério) sintetizados a partir de cloretos formam uma estrutura lamelar organizada, que se transforma num sistema poroso desordenado após a calcinação para a retirada do molde. O processo de decomposição/remoção do molde até $540^{\circ} \mathrm{C}$ produz mudanças de fase nos precursores a base dos metais utilizados, além das transformações morfológicas. Para uma concentração de $90 \%$ de $\mathrm{CeO}_{2}$ obtém-se um material poroso com paredes homogêneas de estrutura $f c c$ e de maior estabilidade mecânica. Os valores de área superficial e volume de poros dependem fundamentalmente do método de preparação do material e independem da concentração de $\mathrm{CeO}_{2}$. Aumentos significativos da área superficial $\left(\approx 100 \mathrm{~m}^{2} / \mathrm{g}\right)$ e do volume de poros $\left(\approx 0,4 \mathrm{~cm}^{3} / \mathrm{g}\right)$ são obtidos a partir da introdução de sílica nesses sistemas. Foram alcançados área superficial $\approx 6$ vezes maior e tamanho de cristalito 4 vezes superior à do material similar nanocristalino preparado por gel-combustão. Esses valores também são iguais aos reportados para os melhores materiais porosos a base de zircônia-céria, preparados por outros métodos, encontrados na literatura. 



\section{Abstract}

In this work synthesis of $\mathrm{ZrO}_{2}-\mathrm{x} \% \mathrm{CeO}_{2}$ were developed, based on the formation of ordered mesoporous silica SBA-15, using the triblock co-polymer Pluronic P-123 as template, different precursors of zirconium and cerium and different methods. The tested synthesis methods were with: hydrated chloride precursors (with $\mathrm{x}=50,70$ and 90 ), anhydrous chloride precursors ( $\mathrm{x}=50$ and 90 ), nitrate precursors $(\mathrm{x}=90)$, supersaturated nitrate solution ( $\mathrm{x}=90$ ), hybrid type with $\mathrm{Zr}$, Ce and Si (with $10 \% \mathrm{~mol}$ of Si and $\mathrm{x}=90$ ), Si palisade (with 10 e $30 \% \mathrm{~mol}$ of Si and $\mathrm{x}=90$ ) and Si palisade with synthesis temperature of $40^{\circ} \mathrm{C}$ (with $30 \% \mathrm{~mol}$ of $\mathrm{Si}$ and $\mathrm{x}=90$ ). Aiming to obtain crystalline single phase walls and large superficial area, for future applications in catalysis. The composites polymer/zirconium-cerium synthesized from chloride precursors formed an organized lamellar structure, which transforms into a disordered porous system after the calcination to remove the template. The template decomposition/removal up to $540^{\circ} \mathrm{C}$ produces phase transformations in the metallic precursors, besides morphological changes. A $\mathrm{CeO}_{2}$ content of $90 \%$ resulted in a porous material with homogeneous walls of $f c c$ structure and better mechanical stability. The values of superficial area and pore volume depend mostly on the preparation method rather than the $\mathrm{CeO}_{2}$ concentration. Significant increases on superficial area $\left(\approx 100 \mathrm{~m}^{2} / \mathrm{g}\right)$ and pore volume $\left(\approx 0.4 \mathrm{~cm}^{3} / \mathrm{g}\right)$ were obtained with the introduction of silica into the material. Superficial area $\approx 6$ times larger and crystallite size 4 times superior to a nanocrystalline similar material, made by gel-combustion were attained. These figures are also equal to the ones reported for the best porous zirconia-ceria materials, prepared by other routes, found in the literature. 



\section{Capítulo 1}

\section{Estado da arte}

\subsection{Materiais porosos e aplicações}

Sólidos porosos são utilizados como adsorventes, catalisadores ou como suporte para catálise, uma vez que são materiais que apresentam alta área superficial S, onde 100 $\lesssim \mathrm{S} \lesssim 1000 \mathrm{~m}^{2} / \mathrm{g}$, quando comparados com materiais maciços "in bulk". Os materiais porosos são classificados pela IUPAC (International Union of Applied Chemistry) de acordo com o diâmetro dos poros (d) em, microporosos (d $<2 \mathrm{~nm})$, mesoporosos $(2<$ $\mathrm{d}<50 \mathrm{~nm})$ e macroporosos $(\mathrm{d}>50 \mathrm{~nm})$.

Em 1992, a preparação de materiais como o MCM-41 (Mobil Composition of Mater), empregando um surfactante iônico como molde, com paredes de sílica amorfa, um arranjo regular de poros ordenados e uma distribuição de tamanho de poros muito estreita (da ordem de 2nm), deu um novo rumo à pesquisa de sistemas mesoporosos [7, 8, 9, 10.

No início, a pesquisa nesses sistemas concentrava-se na síntese de outros materiais (metálicos e não metálicos), baseada no conceito da síntese do MCM-41, e também no mecanismo de formação e na caracterização desses sistemas.

A difração de raios X do MCM-41 apresenta tipicamente entre 3 a 5 reflexões a baixo ângulo, indexadas como (100), (110), (200), (210) e (300), do arranjo de tubos de sílica na forma hexagonal bidimensional (P6m). Uma vez que esses materiais não são cristalinos em nível atômico, não são encontradas reflexões para ângulos maiores. A família de materiais M41S, à qual o MCM-41 pertence é representada juntamente com os difratogramas de raios X, na figura 1.1]7. Uma imagem e uma ilustração dessa estrutura são apresentadas na figura 1.2 .

Atualmente a pesquisa em materiais porosos ordenados tem por objetivo controlar o tamanho, a forma e a uniformidade do espaço "vazio" e os átomos e moléculas que o definem. Com isso pretende-se melhorar a interação do material com outros átomos, íons e moléculas, não apenas na superfície, mas também dentro do volume do material. Dentro desse contexto, na última década ocorreram avanços significativos na 


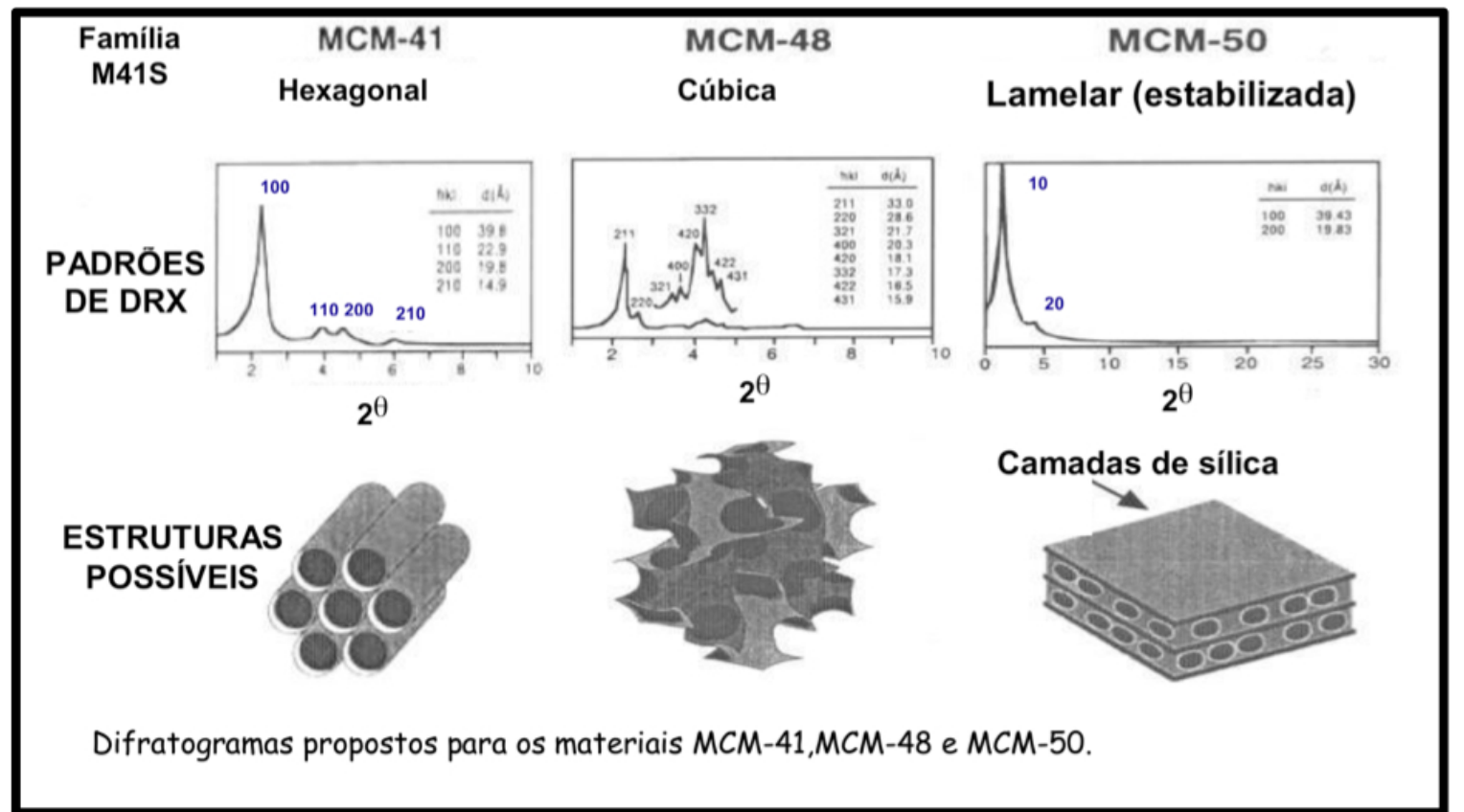

Figura 1.1: Estruturas de poros hexagonal, cúbica e lamelar da família M41S (L. C. Cides da Silva, IQ-USP. Dissertação de Mestrado, 2003).

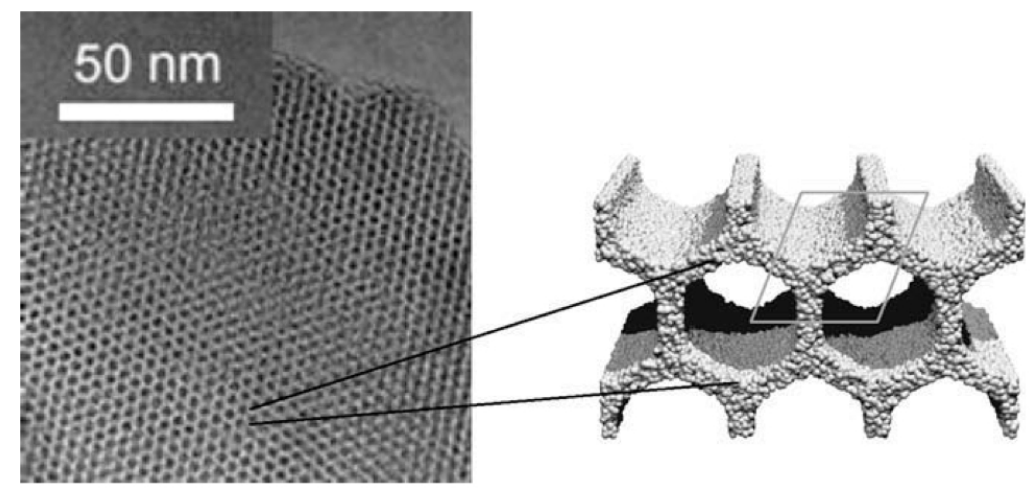

Figura 1.2: Imagem de microscopia eletrônica de transmissão do MCM-41, no detalhe, o formato dos poros em estrutura bidimensional hexagonal[1].

preparação de novos sólidos com estrutura de poros ordenados, utilizando uma vasta gama de materiais [2, [8, 11].

Esses avanços permitiram a produção de sistemas com propriedades não usuais, 
ampliando as tradicionais áreas de aplicação em catálise e absorção, para outras áreas, indo desde a microeletrônica até diagnóstico médico 12 .

A formação de estruturas cúbicas ou hexagonais em sílicas mesoporosas depende dos tipos de precursores, das condições de síntese, como por exemplo, a concentração do molde, pH do meio, do tempo de agitação, da temperatura e do tempo do tratamento hidrotérmico[1, 8].

O mecanismo de formação desses materiais, utilizando surfactantes iônicos é proposto em três passos, primeiramente os ânions de silicato agem como ligantes fortes para as cabeças catiônicas do surfactante, formando uma fase lamelar de surfactante/silicato. Em seguida, a polimerização do silicato ocorre preferencialmente na região de interface, levando a uma redução da carga negativa nessa interface. Por fim, a combinação de densidade de carga entre o surfactante e a sílica levam a uma transformação de fase, formando um compósito hexagonal.

O aumento da concentração de surfactante promove a formação de tubos de silicato auto-organizados (figura 1.3). Outras concentrações ou tipos de surfactante podem levar a outras estruturas (cúbica e lamelar), como mostrado na figura 1.1] 8 ].

Quando a família M41S foi descoberta e analisada, haviam muitas expectativas com relação às aplicações, como por exemplo, na indústria petroquímica para a utilização desses materiais na filtragem de resíduos pesados de soluções contaminadas, usualmente realizado com peneiras moleculares (zeólitas) [12, 13].

Stucky e Monnier propuseram a substituição de silicatos por óxidos metálicos, primeiramente óxido de tungstênio e antimônio, que foram sintetizados a partir de surfactantes catiônicos gerando estruturas hexagonais bidimensionais. No caso do óxido de molibdênio formou-se uma estrutura lamelar[2].

Em 1998, foi obtido um grande progresso na síntese de novos materiais mesoporosos ordenados através do uso de moldes de copolímeros di- e tri-bloco 10, 14. Esses polímeros, com partes hidrofílica e hidrofóbica, mas eletricamente neutros, dão origem a materiais com mesoporos ordenados de diferentes simetrias. Esses direcionadores de estrutura produzem sílicas com tamanho de poro entre 5 a $30 \mathrm{~nm}$ (com utilização de agentes dilatadores de poro, como 1,3,5-trimetilbenzeno, TMB), área superficial em torno de $1000 \mathrm{~m}^{2} / \mathrm{g}$ e espessura das paredes entre poros de 3 a $4 \mathrm{~nm}$ após a remoção total do polímero através da calcinação, feita com temperatura $\approx 500^{\circ} \mathrm{C}[15$, 16]. Essas sílicas com estrutura bidimensional hexagonal são conhecidas como SBA-15. O mecanismo de formação dessas estruturas é esquematizado na figura 1.4.

Também, na área de catálise, a incorporação de alumínio em estruturas de sílica mesoporosa ordenada é capaz de gerar sítios mais ácidos. Entretanto, esses aluminosilicatos não apresentam um potencial catalítico tão maior quando comparado a outros materiais, o que pode ser atribuído ao fato das paredes serem formadas de sílica amorfa[2, 8].

A extensão do processo de síntese utilizando polímeros como agentes direcionadores de estrutura na formação de óxidos metálicos mesoporosos já foi pesquisada $\left(\mathrm{TiO}_{2}\right.$, 


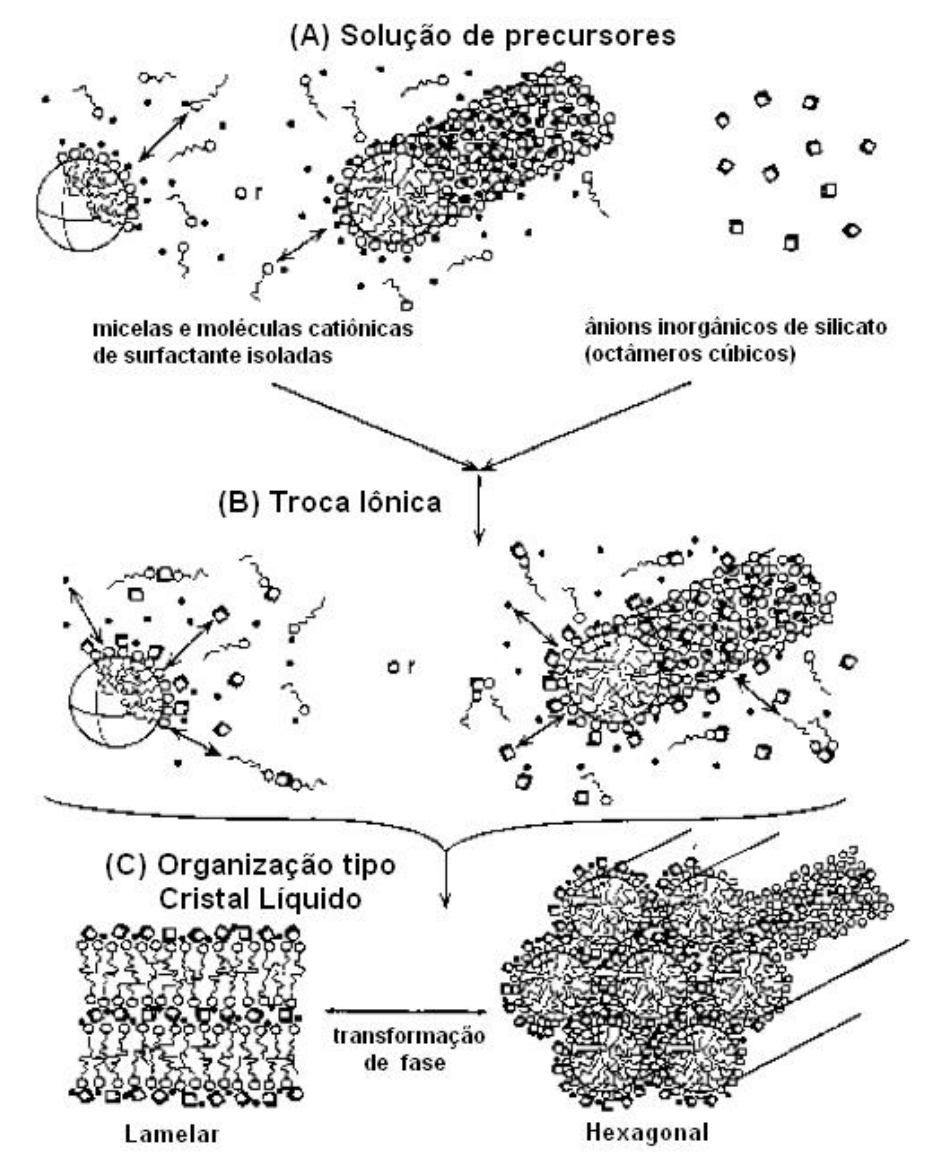

Figura 1.3: Representação do mecanismo de formação de auto-agregação na síntese com troca iônica[2].

$\mathrm{ZrO}_{2}, \mathrm{Nb}_{2} \mathrm{O}_{5}, \mathrm{Ta}_{2} \mathrm{O}_{5}$, etc) [17]. Entretanto, a estabilidade térmica e mecânica desses materiais ainda não foi completamente analisada. Acredita-se que essa estabilidade esteja relacionada principalmente à estrutura das paredes dos poros, pois durante a calcinação para a remoção do molde os metais se transformam em óxidos e as paredes se tornam semi ou totalmente cristalinas. Essa transformação pode ser responsável pela perda de ordenação das estruturas porosas, diferentemente do que ocorre com as paredes de sílica, que permanecem amorfas após a calcinação, bem como, com poros ordenados [2, 5, 11, 17, 18].

Em particular, materiais mesoporosos a base de zircônia, com alta área superficial, são potenciais candidatos para uso em catálise e em células combustíveis de óxido sólido ou Solid Oxide Fuel Cells, conhecidas como SOFC's, em sua maioria confeccionadas com zircônia dopada com ítria (comumente chamada de YSZ, ou Yttria Stabilized 


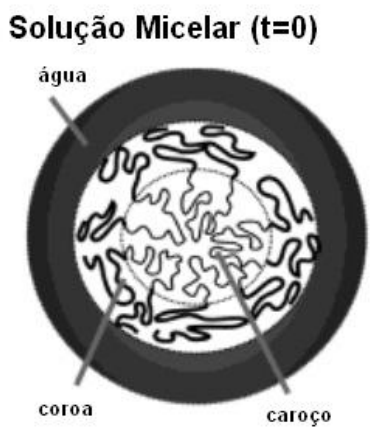

Estágio (b) (t=5-60min)

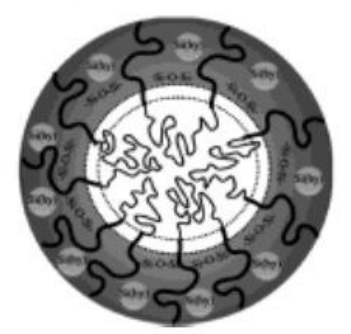

Estágio (a) $(\mathrm{t}=<5 \mathrm{~min})$

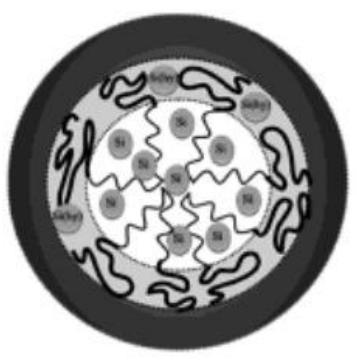

Estágio (c) $(\mathrm{t}=1-2 \mathrm{~h})$

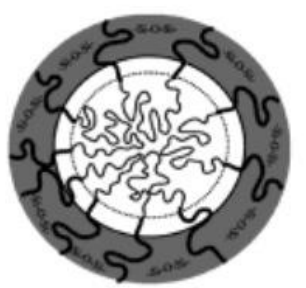

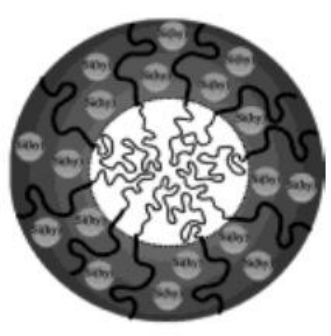

Estágio (d) $(\mathrm{t}>2 \mathrm{~h})$

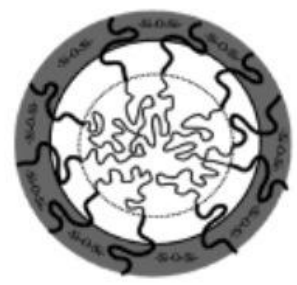

Figura 1.4: Representação do mecanismo de formação de materiais mesoporosos com copolímeros 3 .

Zirconia), que possibilita a estabilização de fases não estáveis da zircônia que possuem melhores características para essas aplicações[19, 20, 21, 22, 23, 24].

No processo de conversão de gases, $\mathrm{ZrO}_{2}$ mesoporosa é capaz de aumentar a estabilidade de catalisadores de níquel em relação a materiais convencionais, como mostra a figura 1.5. As amostras apresentadas são de zircônia mesoporosa com alta dispersão de $\mathrm{Ni}$ (5, 7 e 10\%), sintetizadas com o polímero Pluronic P-123 e apresentam alta área superficial. Essas amostras possuem estabilidade em altas temperaturas, permanecendo ativa por até 50 horas de reação, enquanto a amostra sintetizada pelo processo de precipitação convencional, foi rapidamente desativada pela formação de resíduos carbonáceos após combustão 35 .

$\mathrm{A}$ adição de $\mathrm{CeO}_{2}$ e a formação de óxidos de Ce-Zr é pesquisada pois esses metais combinados tem aplicações em catálise. A céria é eficiente em processos de transferência de elétrons, em que a condução iônica ocorre em virtude das vacâncias de oxigêncio existentes na sua estrutura cristalina e, a presença da zircônica pode contribuir para aumentar esses defeitos da rede[25]. Ultimamente esses sistemas tem sido estudados para aplicação em catálise automobilística, SOFC's, componentes para absorção de radiação ultravioleta, materiais utilizados em polimento de vidros, etc[26, 27].

Os eletrodos da SOFC exigem especificações rígidas devido à sua operação em 

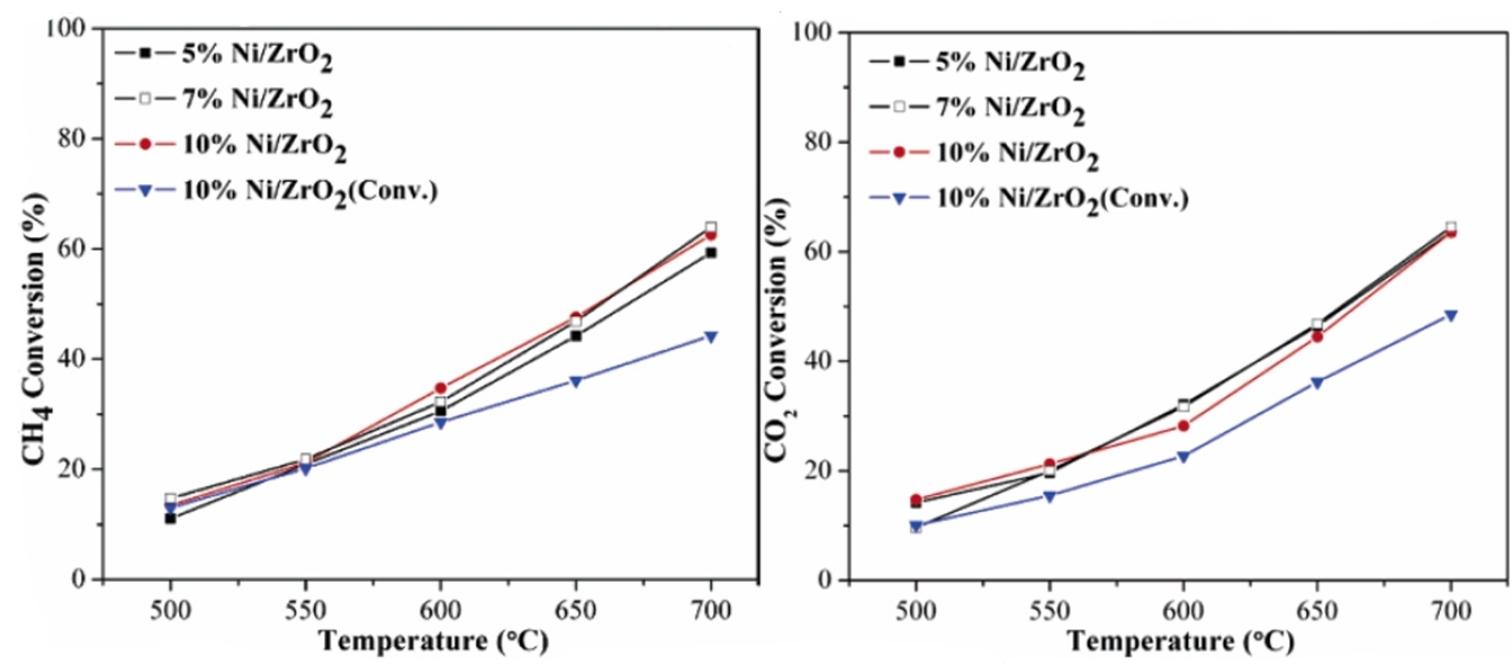

Figura 1.5: Resultados para a conversão de metano $\left(\mathrm{CH}_{4}\right)$ e dióxido de carbono $\left(\mathrm{CO}_{2}\right)$ com Ni disperso em matriz de zircônia mesoporosa em comparação a uma amostra convencional de zircônia com $10 \%$ de Ni sintetizada por precipitação (Conv.) [35].

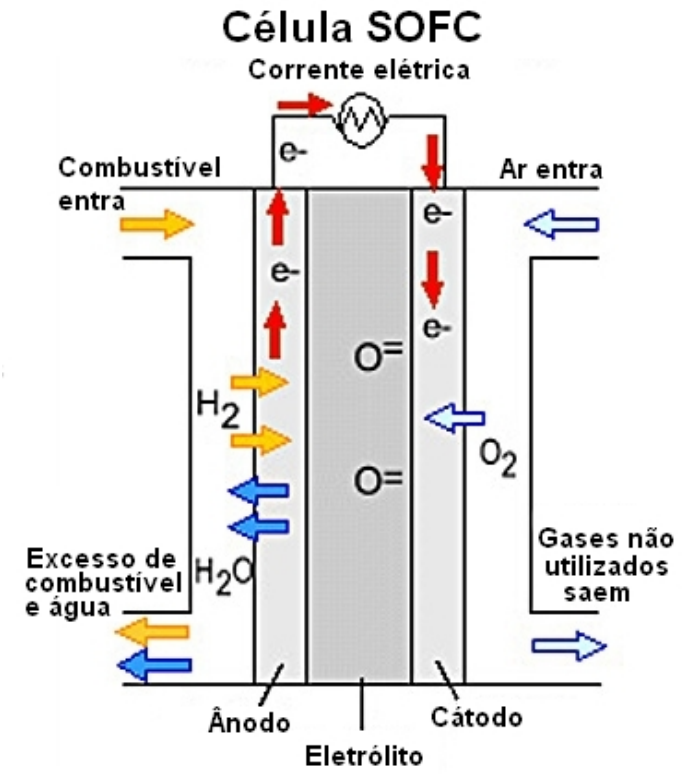

Figura 1.6: Representação esquemática de funcionamento de uma célula combustível de óxido sólido (SOFC), (U.S.Dept. of Energy-EERE). 
altas temperaturas $\left(\approx 1000^{\circ} \mathrm{C}\right)$, o que requer alta estabilidade térmica e controle de reatividade química, fase, morfologia, expansão térmica, morfologia, condutividade iônica, etc[21]. O ânodo da célula pode ser confeccionado com zircônia estabilizada com ítria ou céria; o cátodo, com magnetitas de estrôncio e lantânio (LSM) e, o condutor de íons de oxigênio, o eletrólito, pode também ser fabricado de zircônia. A célula é alimentada com combustível, no caso da figura 1.6, com gás hidrogênio e ar. Os íons $\mathrm{O}^{2-}$ migram do cátodo ao ânodo, reagem com o combustível gerando uma corrente elétrica no sistema 25, 23, 24].

Sistemas de zircônia-céria e ítria, também em SOFC's levam a melhoras importantes no transporte mássico combustível/oxidante, na mobilidade do íon metálico, na condutividade eletrônica e na transferência de carga, permitindo atingir um limite de temperatura de operação mais baixa, através da retenção de fases metaestáveis que favorecem reações de difusão de gases[21, 25, 26, 27].

Em diversos sistemas com óxido de zircônio são observadas três formas da fase tetragonal, denominadas t, t' e t", todas correspondentes ao grupo espacial $\mathrm{P} 4_{2} / \mathrm{nmc}$ [26, 28, 29, 30, 31, 32]. Isso ocorre para soluções sólidas homogêneas em composição. As três formas da fase tetragonal apresentam uma estrutura cristalina muito similar à fase cúbica ( $f c c$, tipo fluorita). A forma t é a forma de equilíbrio do diagrama de fases e está restrita ao limite de solubilidade previsto no diagrama. A forma t' apresenta a maior solubilidade mas é instável, e no equilíbrio se transforma numa mistura de fases tetragonal (t) e cúbica. As formas t e t' apresentam razão axial c/a entre 1,005 e 1,015. Para concentrações de dopante maiores existe uma terceira forma tetragonal, chamada t", com $c / a=1$, mas com os ânions $\mathrm{O}^{2-}$ deslocados das suas posições na fase cúbica, na direção de c. Finalmente, aumentando-se mais a concentração do dopante, se retém a fase cúbica. E nessa fase, os ânios $\mathrm{O}^{2-}$ apresentam coordenadas fracionárias $(1 / 41 / 41 / 4)$ e equivalentes por simetria, entretanto na fase tetragonal os ânions estão em $(1 / 4 \mathrm{c} / 4$ $z(O)$ ), e equivalentes por simentria, com z $(O)$ entre 0 e $1 / 4$. As fases são representadas na figura 1.7 .

$\mathrm{O}$ uso de $\mathrm{ZrO}_{2}-\mathrm{x} \% \mathrm{MO}_{y}(\mathrm{M}=\mathrm{Y}, \mathrm{Ce}, \mathrm{Sc}, \mathrm{Ca}$, etc)[27, 29, 33, 34] em aplicações catalíticas e em SOFCs requer alta área superficial, o que pode ser conseguido em sistemas de nanopartículas preparadas através de métodos sol-gel ou gel-combustão 5 , 26, 35, 36, 37. Esses processos de síntese também estabilizam fases cristalográficas metaestáveis[26], que apresentam melhor desempenho nas aplicações de interesse.

As primeiras tentativas de preparar $\mathrm{ZrO}_{2}$ mesoporosa ordenada foram feitas com precursores a base de sulfatos e surfactantes catiônicos, gerando estruturas hexagonais bidimensionais e lamelares, de acordo com a quantidade de $\mathrm{Zr} /$ surfactante. No entanto, mesmo com outros métodos de calcinação mais lentos ou extração por solvente observase que a estrutura ordenada é perdida depois da remoção do molde[2]. Particularmente, sistemas lamelares são instáveis mecanicamente após a remoção do molde, ou seja, a estrutura porosa ordenada não é preservada. O tratamento pós síntese, onde $\mathrm{ZrO}_{2}$ é adicionada a um suporte de SBA-15 ou sínteses com uma razão baixa de $\mathrm{Si} / \mathrm{Zr}$ também 

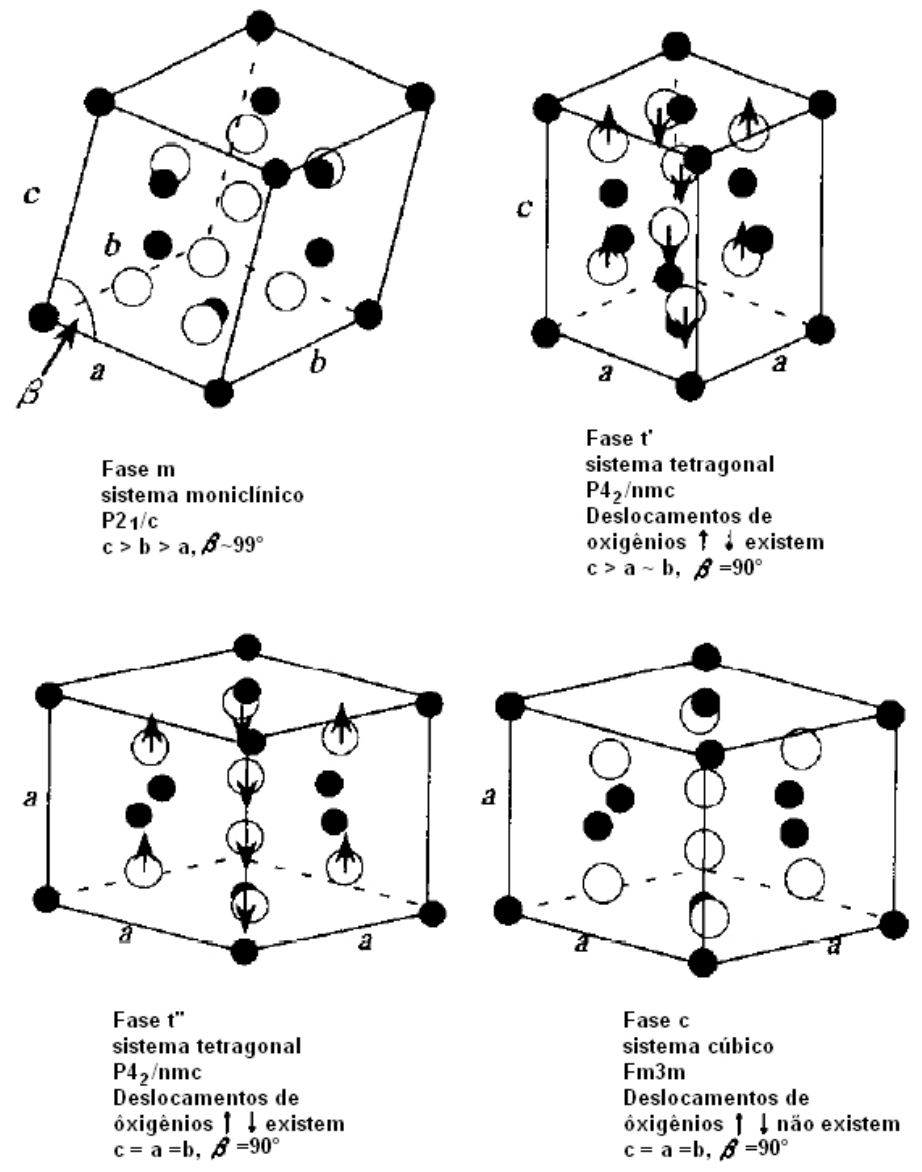

Figura 1.7: Fases do óxido de zircônio[30].

podem aumentar a capacidade de adsorção de gases em relação a zirconia maciça 11. Nesses casos, a sílica pode ser dissolvida através do uso de $\mathrm{HF}$ ou $\mathrm{NaOH}[11$, 38], gerando uma matriz apenas de óxido metálico de zircônio.

A preparação de $\mathrm{CeO}_{2}$ mesoporosa ordenada com surfactantes neutros é descrita na literatura. Após calcinação, em torno de $500^{\circ} \mathrm{C}$, o material apresenta área superficial de $\approx 100 \mathrm{~m}^{2} / \mathrm{g}[39$, 40].

\subsection{Motivação e objetivos}

Até o presente há poucos trabalhos que exploram a síntese e aplicação de materiais mesoporosos à base de zircônia-céria com grande área superficial (maior que $100 \mathrm{~m}^{2} / \mathrm{g}$ ) 41, 42, 43, 44, 45]. 
Em vista disso, nesse trabalho investimos na preparação de $\mathrm{ZrO}_{2}-\mathrm{x} \% \mathrm{CeO}_{2}$ utilizando a metodologia de síntese de sílicas mesoporosas [10, 14 do tipo SBA-15, a partir de diversos precursores e diferentes métodos de preparo, visando obter fase cristalina única das paredes de óxido de zircônio e cério e, grande área superficial.

Nesse trabalho, as concentrações nominais molares de $\mathrm{CeO}_{2}$ estudadas foram de $\mathrm{x}=$ 50, 70 e 90\%. Essas concentrações foram escolhidas de forma a obter fase única (cúbica ou tetragonal) nas paredes do material. As fases tetragonal e cúbica apresentam melhor desempenho em processos catalíticos e como componentes em SOFC's[27.

As técnicas de análise utilizadas foram espalhamento de raios $\mathrm{X}$ a baixo ângulo (para analisar a estrutura ordenada dos poros), difração de raios X a alto ângulo (para analisar a estrutura das paredes) e isotermas de adsorção de $\mathrm{N}_{2}$ (para avaliar a distribuição de tamanho de poros e área superficial).

A seguir, no capítulo 2 serão apresentados os métodos de caracterização utilizados nesse trabalho. No capítulo 3 os resultados obtidos serão apresentados e discutidos qualitativamente. No capítulo 4 os resultados serão comparados quantitativamente e as conclusões serão apresentadas. Finalmente, no capítulo 5 serão levantados alguns problemas parcialmente analisados nesse trabalho e que serão investigados em trabalhos futuros. 



\section{Capítulo 2}

\section{Técnicas experimentais de análise}

\subsection{Difração de raios X (XRD)}

A difração de raios X é um fenômeno de interação entre a radiação eletromagnética e a matéria ordenada. Para a ocorrência da difração de raios $\mathrm{X}$ a altos ângulos é necessário que o comprimento de onda da radiação incidente seja da mesma ordem de grandeza do espaçamento interatômico $(\lambda \approx 0,1 \mathrm{~nm})$.

Os raios $\mathrm{X}$ são produzidos quando elétrons com alta velocidade colidem com a matéria e são desacelerados, emitindo radiação. Um elétron a alta velocidade pode remover um elétron de caroço de um átomo. Quando esta camada interna fica ionizada, um elétron de uma camada mais externa pode se deslocar para esta posição vazia, liberando uma energia bem definida na forma de raios $\mathrm{X}$ característico (radiação $\mathrm{K}_{\alpha}$, $\mathrm{K}_{\beta}$, etc.) do átomo.

A incidência dos raios $\mathrm{X}$ sobre um átomo provoca o espalhamento de radiação em todas as direções. A interferência construtiva dos raios $\mathrm{X}$ espalhados, proveniente de vários átomos, caracteriza a difração. No caso de um cristal, a sequência periódica de átomos, pode ser visualizada como um conjunto de planos cristalográficos, indexados através dos índices de Miller, hkl[46].

O espalhamento coerente dos raios X (mesma energia da radiação incidente) por um conjunto de planos cristalinos (hkl) ocorre em um ângulo bem definido, denominado ângulo de Bragg. A condição de difração é estabelecida pela lei de Bragg. A figura 2.1, onde os planos XX' e YY' estão separados por uma distância $\mathrm{d}_{h k l}$, mostra um feixe de raios $\mathrm{X}$ incidente, em fase, em um sólido organizado (cristal) e o feixe espalhado pelos elétrons no sólido em $\mathrm{O}$ e O'.

A diferença de caminho ótico entre esses feixes é dada pela distância $\overline{A B C}$ e o ângulo de espalhamento entre o feixe incidente e espalhado é dado por $\widehat{A O C}=2 \theta$. Através da figura, temos que: 


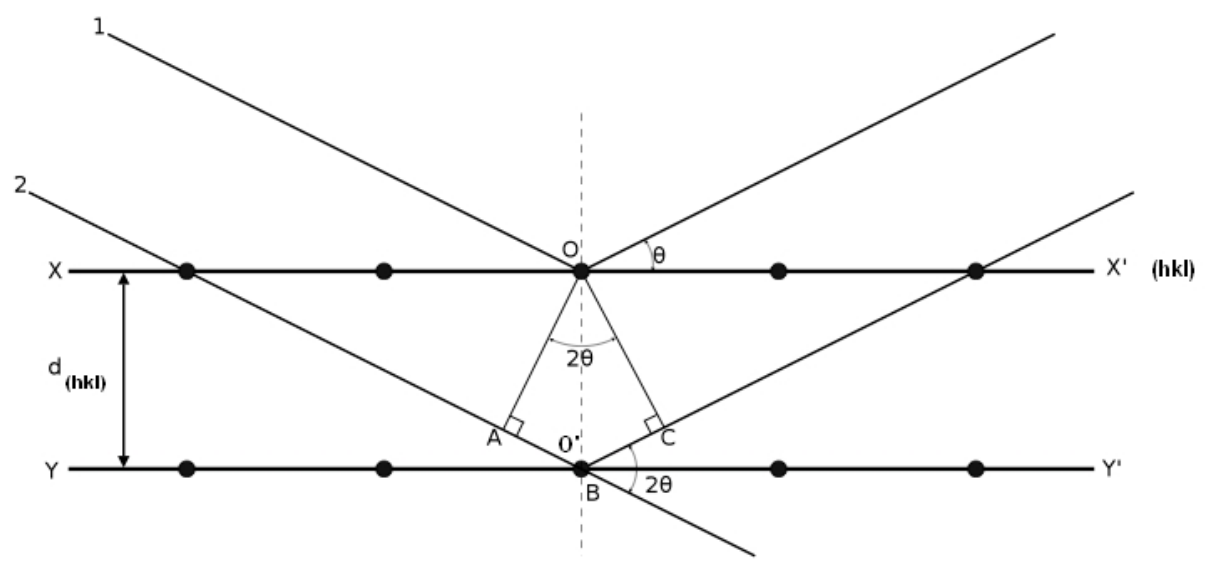

Figura 2.1: Representação da difração de raios X por um cristal.

$$
\overline{A B}=\overline{B C}=d_{h k l} \operatorname{sen} \theta_{h k l}
$$

A condição de interferênia construtiva (pico) ocorre se a diferença de fase entre os feixes espalhados por O e O' é um múltiplo de $2 \pi$. Para isso a diferença de caminho ótico entre os dois feixes deve ser um múltiplo inteiro do comprimento de onda, logo:

$$
m \lambda=2 d_{h k l} \operatorname{sen} \theta_{h k l}
$$

onde $\lambda$ é o comprimento de onda da radiação incidente, $\mathrm{d}_{h k l}$ é a distância interplanar e $\theta_{h k l}$ é o semi-ângulo de difração medido em relação aos raios X incidentes e m, a ordem de difração. A equação 2.2 é a Lei de Bragg para a difração de raios X. Os valores de $\mathrm{d}_{h k l}$ para compostos padrão estão tabelados, disponíveis no sistema ICDD (JCPDS) [46]. O objetivo fundamental da análise cristalográfica é determinar a localização exata de todos os átomos num cristal. Para isso é importante conhecer todas as possíveis formas de arranjos de pontos (átomos) no espaço.

A partir da análise do feixe difratado obtém-se informação sobre o arranjo atômico do cristal, ou seja, simetria e distâncias interatômicas que determinam a chamada cela unitária. Esta análise requer o conhecimento das simetrias envolvidas no empacotamento dos átomos que formam o material, ou seja, de sua estrutura cristalina. Existem 6 sistemas de simetria cristalina: triclínico, monoclínico, ortorrômbico, tetragonal, hexagonal e cúbico. A partir desses dados é possível indexar uma determinada amostra, ou seja, obter informações estruturais de interesse como os parâmetros de rede, que representam a menor distância entre dois pontos equivalentes de uma estrutura ordenada $(\mathrm{a}, \mathrm{b}, \mathrm{c})$ e os ângulos $(\alpha, \beta, \gamma)$ entre suas direções [46]. 
Neste trabalho, as amostras de zircônia-céria foram analisadas por XRD no Laboratório de Cristalografia do IF-USP. O equipamento utilizado nesses experimentos foi um difratômetro da marca Rigaku, modelo Ultima Plus, geometria $\theta-\theta$ e monocromador de grafite.

Todas as amostras foram trituradas num almofariz com um pistilo, para garantir a homogeneidade do tamanho dos grãos morfológicos da amostra. Uma pequena quantidade de graxa de vácuo foi espalhada em uma lamínula de vidro, onde a amostra foi prensada com o auxílio de uma segunda lamínula.

As condições de medida para as amostras foram de $40 \mathrm{kV}$ e $20 \mathrm{~mA}$, radiação $\mathrm{K}_{\alpha}$ do cobre $(\lambda=0,15418 \mathrm{~nm})$ com o ângulo $2 \theta$ variando de 10 a $100^{\circ}$, com o tempo de contagem de 5 s a cada passo de $0.05^{\circ}$.

Medidas de XRD também foram realizadas na linha XPD do LNLS, $\operatorname{com} \lambda=$ 0,15498nm, no início do trabalho para identificação precisa das fases cristalinas produzidas como função da concentração de $\mathrm{CeO}_{2}$ nas amostras. Essas medidas serão descritas com mais detalhe a seguir.

\subsection{Espalhamento de raios $\mathrm{X}$ a baixo ângulo (SAXS)}

SAXS (Small Angle X-ray Scattering) é uma técnica muito utilizada para a análise de partículas (ou fase subdividida) de dimensões coloidais dispersas em uma matriz de densidade eletrônica homogênea. SAXS é uma técnica importante para analisar materiais heterogêneos, caracterizar estruturas fractais, materiais nanoporosos, separação de microfases, compósitos nanocristalinos, polímeros, proteínas, dentre outros sistemas com variação de densidade eletrônica, na faixa de 0,5 a $50 \mathrm{~nm}$.

As análises realizadas baseiam-se principalmente nas teorias de Guinier e Porod, as quais possibilitam estudar a concentração relativa das densidades eletrônicas, distribuição de raios, correlação e a forma das partículas dispersas [4].

A representação de uma amostra como sendo formada por "partículas" dispersas num meio uniforme (matriz) ou uma matriz de densidade homogênea com poros (vazios) é muito útil na descrição de resultados de SAXS, uma vez que as "partículas" e os poros podem ser consideradas heterogeneidades com densidades eletrônicas diferentes da matriz.

A técnica de espalhamento de raios $\mathrm{X}$ a baixo ângulo está associada a medidas de ângulos de espalhamento em torno de 0,1 a $10^{\circ}$, onde esses limites dependem do arranjo experimental. Objetos grandes em relação ao comprimento de onda dos raios $\mathrm{X}$ incidentes (por exemplo, $1 \mu \mathrm{m}$ ) produzem espalhamento em ângulos muito baixos, sendo praticamente confundidos com o feixe que vem direto da fonte durante a deteção[4]. A intensidade do espalhamento de raios X nessa faixa de pequenos ângulos não contém informações sobre a densidade eletrônica associada à natureza atômica do material, esse tipo de informação é obtida ângulos maiores (XRD). 


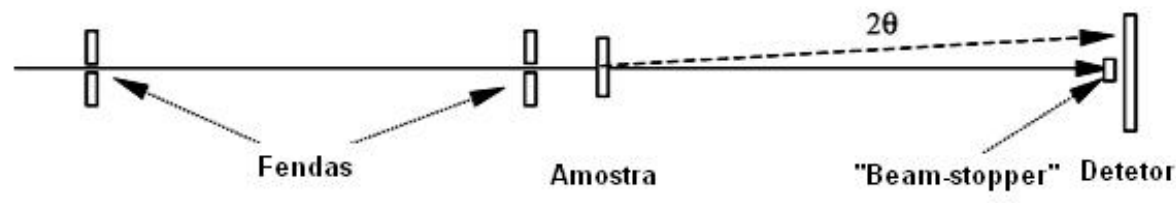

Figura 2.2: Montagem para um equipamento de SAXS[4].

Geralmente o experimento de SAXS é feito pelo método de transmissão, mostrado na figura 2.2. e para cada estado de organização eletrônica e raio da "partícula", temos um perfil de espalhamento, de acordo com as figuras $2.3 \mathrm{e} 2.4$.
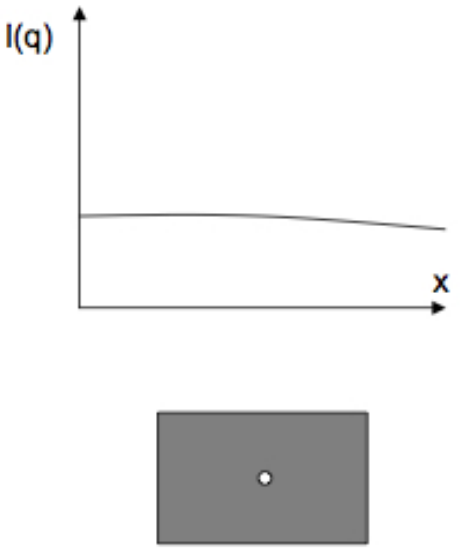

$\mathrm{R} 1 \approx 1 \mu \mathrm{m}$
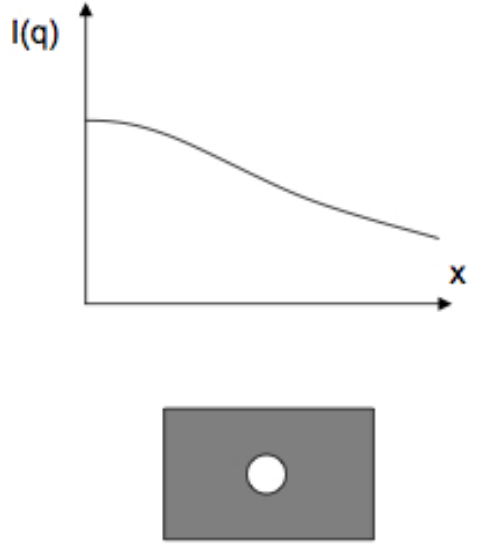

$\mathrm{R} 2 \approx 5 \mu \mathrm{m}$
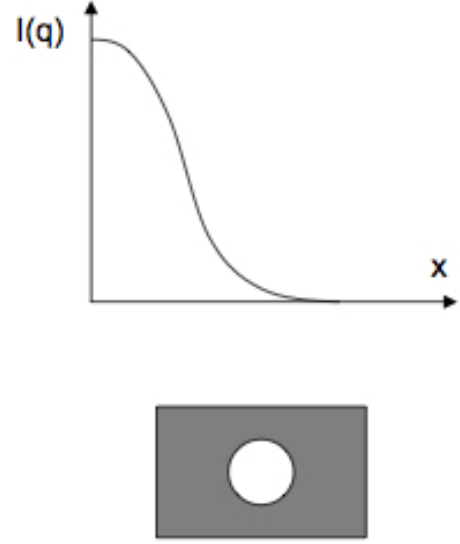

$\mathrm{R} 3 \approx 20 \mu \mathrm{m}$

Figura 2.3: Intensidade espalhada para 3 esferas de raios diferentes, onde $\mathrm{x}=\mathrm{q}$ (vetor de espalhamento, $q=(4 \pi / \lambda) \operatorname{sen} \theta_{h k l}$ (A. F. Craievich, com permissão). 

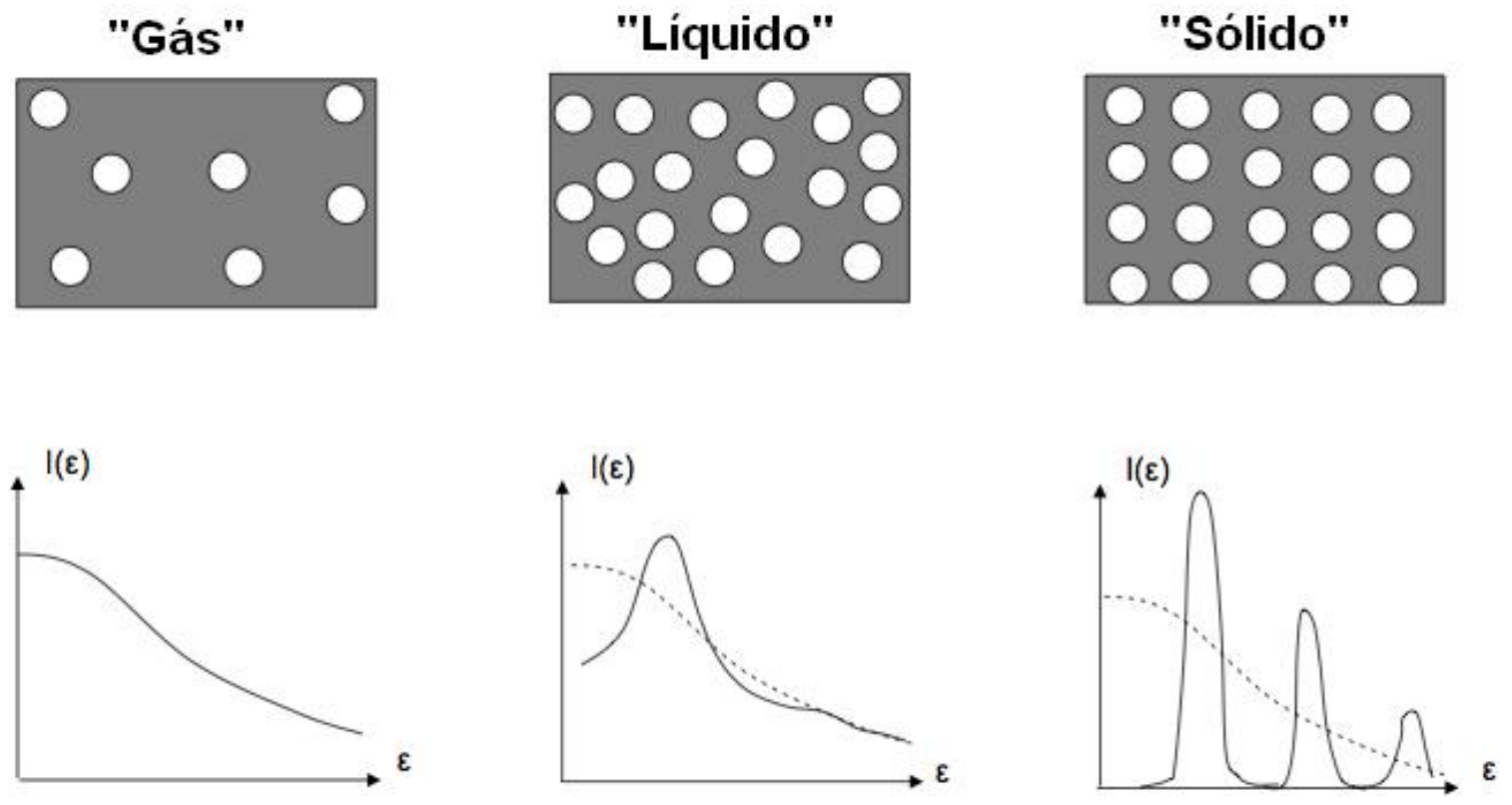

Figura 2.4: Intensidade espalhada para um gás, líquido e um sólido organizado, onde $\epsilon=2 \theta$ (A. F. Craievich, com permissão).

A difração a baixo ângulo ocorre quando as "partículas" na matriz ou poros apresentam organização. Os poros de diâmetro $2 \lesssim \mathrm{d} \lesssim 50 \mathrm{~nm}$ das sílicas mesoporosas, em especial do tipo SBA-15, apresentam uma estrutura hexagonal bidimensional, de acordo com a figura 2.5, com estrutura similar ao MCM-41 já descrito.

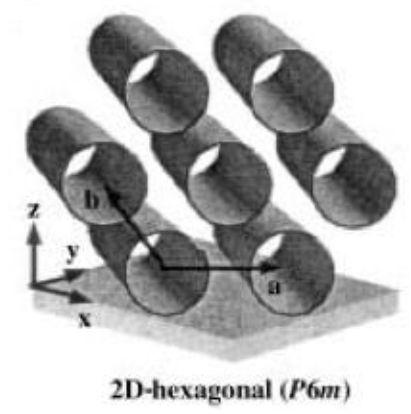

Figura 2.5: Esquema da estrutura de poros hexagonal bidimensional da sílica SBA$15[5]$.

Para essa simetria temos: 


$$
\frac{1}{d_{h k l}^{2}}=\frac{4}{3}\left(\frac{h^{2}+h k+k^{2}}{a^{2}}\right)+\frac{l^{2}}{c^{2}}
$$

onde $\mathrm{h}, \mathrm{k}$ e $\mathrm{l}$ correspondem aos índices de Miller dos planos cristalográficos, onde a e c são os parâmetros de rede. Como essa estrutura é bidimensional, o parâmetro $l=$ 0, logo o último termo se anula[46]. Nesse caso, temos também que:

$$
a=D+E
$$

onde D é o diâmetro dos poros e E é a espessura da parede. Para uma simetria cúbica[46], temos:

$$
\frac{1}{d_{h k l}^{2}}=\frac{h^{2}+k^{2}+l^{2}}{a^{2}}
$$

E, para uma simetria lamelar[9]:

$$
d_{h 0}=\frac{a}{h}
$$

Os experimentos de SAXS foram realizados no Laboratório de Cristalografia do IFUSP, no equipamento NANOSTAR da Bruker. Esse equipamento possui como fonte de raios $\mathrm{X}$ um tubo selado de $\mathrm{Cu}$. A colimação é feita por espelhos Göbel que selecionam o comprimento de onda $\mathrm{K}_{\alpha}$ do cobre e retiram a maior parte da radiação de fundo. O alinhamento é feito por 3 fendas (pinholes) ao longo da linha do equipamento, que possui um detetor bidimensional multifilamentar a gás. O sistema é controlado com software próprio no computador e programado para realizar as medidas desejadas. O equipamento também dispõe de uma placa de imagem para realizar medidas em ângulos mais altos (WAXS, Wide Angle X-Ray Scattering).

A preparação das amostras para as medidas no Nanostar foram feitas de forma a colocá-las entre duas folhas finas de plástico especial (parasita) e depois encaixá-las no suporte do porta-amostras do equipamento.

A tensão e corrente máximos são de $40 \mathrm{kV}$ e $30 \mathrm{~mA}$. O tempo de exposição depende da amostra. Materiais com maior absorção, como os estudados nesse trabalho, são medidos em média por uma hora com $\mathrm{P}=1,2 \mathrm{kV}$. A distância amostra-detetor é de $65,0 \mathrm{~cm}\left(0,2 \lesssim \mathrm{q} \lesssim 3,5 \mathrm{~nm}^{-1}\right)$ e as amostras são mantidas a vácuo ( $\approx 10^{-2}$ Torr). A transmissão da amostra é medida com o auxílio de um espalhador de carvão vítreo que vem acoplado ao equipamento. 


\subsection{Isotermas de adsorção-dessorção de nitrogênio}

Medidas de SAXS com variação in-situ de temperatura foram realizadas no LNLS para analisar o efeito da calcinação na estrutura ordenada dos sistemas estudados. Detalhes desses experimentos serão fornecidos a seguir.

\subsection{Isotermas de adsorção-dessorção de nitrogênio (NAI)}

Adsorção é um processo onde moléculas de um gás ou de uma solução ligam-se numa camada densa sobre uma superfície sólida ou líquida. As moléculas que interagem com a superfície são chamadas de adsorbato enquanto a substância que adsorve as moléculas é o adsorvente. O processo em que as moléculas do gás se ligam à superfície é chamado de adsorção e a remoção dessas moléculas da superfície é chamado de dessorção.

Através do método de adsorção de gases é possível medir de forma indireta a área superficial de um material poroso, a partir do método Brunauer-Emmet-Teller (BET) [47]; e a distribuição de tamanhos de poros é calculada pelo método Barrett-Joyner-Halenda (BJH) [48].

Há dois tipos de adsorção: na monocamada, onde todo o adsorbato está muito próximo da superfície do sólido adsorvente; e na multicamada, em que existem várias camadas do adsorbato na superfície do adsorvente. A quantidade de gás adsorvido depende da temperatura, pressão e composição do gás. A medida da quantidade de gás adsorvido por um determinado adsorvente a uma temperatura fixa é chamada de isoterma de adsorção.

Isotermas de adsorção em materiais com alta porosidade são diferentes das isotermas de materiais maciços, devido a efeitos de capilaridade. O comportamento das isotermas pode ser classificado em vários tipos, de acordo com a figura 2.6(a).

- Tipo I: isotermas em que a quantidade de gás adsorvido aumenta com o aumento da pressão e satura, com a monocamada preenchida. É característica de adsorção em monocamada, onde o material adsorvente possui poros muito pequenos (microporosos) que se enchem rapidamente.

- Tipo II: quantidade adsorvida aumenta com o aumento da pressão, alcança um patamar e aumenta com pressões altas. Característica de multicamada, em que o material possui baixa porosidade ou poros muito grandes.

- Tipo III: inicialmente apresenta pouca adsorção, mas uma vez que uma pequena gota ou "região de núcleos adsorventes" é formada na superfície a adsorção ocorre mais facilmente.

- Tipo IV e V: ocorrem quando multicamadas de gás são adsorvidos num sólido poroso. Inicialmente, a adsorção parece com o tipo II e III, mas eventualmente 

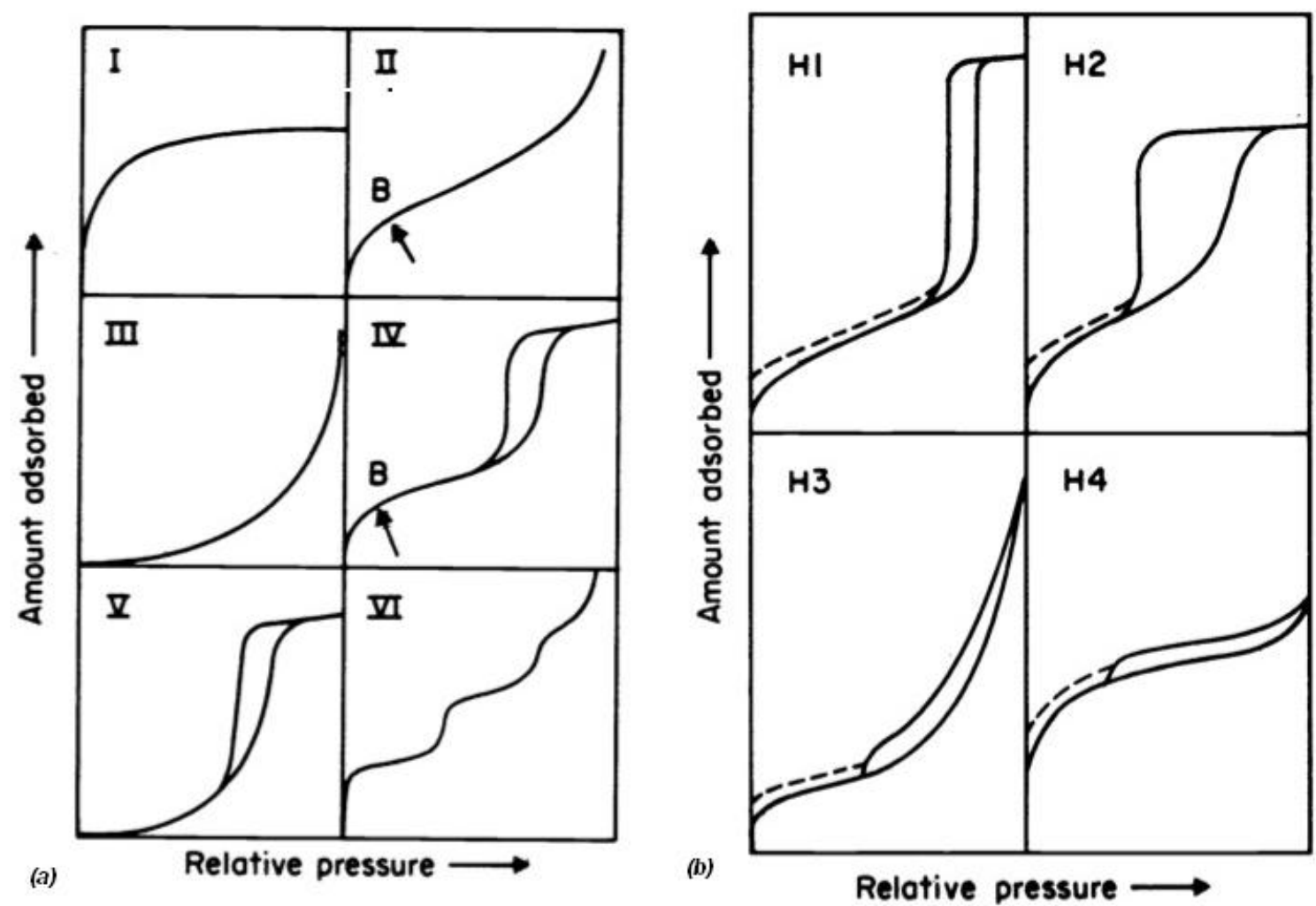

Figura 2.6: (a) Representação dos tipos de isotermas de adsorção descritos por Brunauer; (b) Representação dos tipos de histereses em isotermas de adsorçãodessorção[6].

a camada adsorvida aumenta de forma que os poros ficam preenchidos, como resultado não há mais adsorção e a curva satura.

- Tipo VI (isoterma em degraus) ocorre em superfícies uniformes não porosas e representa uma adsorção camada a camada. A altura do degrau corresponde à capacidade de adsorção da monocamada em cada camada adsorvida.

O fenômeno da histerese, nas isotermas de adsorção, está associado ao fenômeno da condensação capilar em estruturas porosas. Verifica-se então que a curva de adsorção não coincide com a curva de dessorção, isto é, não há reversibilidade, como indicado na figura 2.6(b) para as isotermas do tipo IV e V. As histereses são classificadas segundo a IUPAC em:

- Tipo $\mathrm{H}_{1}$, caracterizado por dois ramos da isoterma quase verticais e paralelos durante uma extensa gama de valores em relação à quantidade adsorvida. Geral- 


\subsection{Isotermas de adsorção-dessorção de nitrogênio}

mente, está associado a materiais porosos constituídos por aglomerados rígidos de partículas esféricas de tamanho uniforme ordenadas regularmente, resultando numa estreita distribuição de tamanho de poros.

- Tipo $\mathrm{H}_{2}$, histerese em que só o ramo de dessorção é praticamente vertical. Muitos adsorventes porosos originam este tipo de histerese, a que corresponde uma distribuição de tamanhos e formato de poros bem definida. Por vezes associa-se este tipo de histerese aos diferentes mecanismos de condensação e evaporação dos poros em forma de gargalo.

- Tipo $\mathrm{H}_{3}$, caracterizado por dois ramos da isoterma assintóticos relativamente à vertical $\mathrm{P} / \mathrm{P}_{0}=1$. Está associado a agregados não rígidos de partículas lamelares, originando poros em formato de fenda.

- Tipo $\mathrm{H}_{4}$, caracteriza-se por dois ramos da isoterma quase horizontais e paralelos durante uma extensa gama de valores de pressão relativa. Este tipo também está associado a poros estreitos em forma de fenda, mas juntamente com o aspecto da isoterma do tipo I indica a presença de microporos [6, 49].

O método BET calcula a área superficial através de um ajuste linear da medida da adsorção de um gás conhecendo-se a área ocupada pela molécula desse gás, de forma a determinar a quantidade adsorvida pela amostra a ser analisada quando se atinge o equilíbrio para cada valor de pressão. Essa medida é feita em condições normais de temperatura e pressão 47 .

O método BJH é baseado no modelo de condensação capilar desenvolvido por Cohan (1938) 49]. Esse método é utilizado para avaliar a distribuição de tamanho de poros de um sólido poroso através da adsorção ou dessorção de gases. Os cálculos são feitos com base na isoterma de adsorção usando os seguintes dados: pressão relativa e volume de adsorbato correspondente e a espessura da camada adsorvida[48].

No Laboratório do Grupo de Pesquisa em Química Verde e Ambiental do IQ-USP (GPQVA) foram realizados experimentos de adsorção/dessorção de $\mathrm{N}_{2}$ para avaliar a distribuição do tamanho de poros, área superficial e volume de poros das amostras.

As isotermas foram medidas a 77,3K no equipamento NOVA (Quantachrome). As amostras foram desgaseificadas a $200^{\circ} \mathrm{C}$ por 2 horas. As áreas superficiais foram calculadas pelo modelo BET e BJH e o tamanho dos poros foram calculadas pelo método $\mathrm{BJH}$ (medidas de $\mathrm{P} / \mathrm{P}_{0}<0,5$ e $\mathrm{P} / \mathrm{P}_{0}>0,5$ ). Entretanto, como os resultados de $\mathrm{BJH}$ apresentaram uma dispersão muito grande de valores de diâmetro de poros, sem qualquer indicação de um tamanho específico, mais característico, esses resultados foram descartados. 



\section{Capítulo 3}

\section{Síntese de $\mathrm{ZrO}_{2}-\mathrm{CeO}_{2}$ poroso: resultados e discussão}

\subsection{Introdução}

As sínteses apresentadas têm como objetivo a preparação de óxidos a base de zircônia e céria com estrutura porosa e paredes compostas por uma fase cristalina homogênea e alta área superficial.

A rota de síntese escolhida utiliza um método de molde (template) cooperativo a partir de polímero tribloco utilizado em sínteses de materiais mesoporosos ordenados de sílica do tipo SBA-15[10, 14].

Um diagrama esquemático da síntese de uma forma geral é apresentado na figura 3.1 .

As amostras de zircônia-céria porosas foram obtidas por vários métodos diferentes, dentro da seqüência ilustrada na figura 3.1. São eles: método cloreto hidratado, método cloreto anidro, método nitrato, método solução supersaturada; métodos de síntese com silício: método híbrido, método paliçada e método paliçada com temperatura de síntese de $40^{\circ} \mathrm{C}$.

\subsection{Métodos de síntese: $\mathrm{ZrO}_{2}-\mathrm{x}_{0} \mathrm{CeO}_{2}$}

- Método cloreto hidratado A preparação destas amostras utilizou como precursores de $\mathrm{ZrO}_{2}-\mathrm{x} \% \mathrm{CeO}_{2}$ (com $\mathrm{x}=50,70$ e 90), oxicloreto de zircônia hidratado $\left(\mathrm{ZrOCl}_{2} \cdot 8 \mathrm{H}_{2} \mathrm{O}\right)$ e cloreto de cério hidratado $\left(\mathrm{CeCl}_{3} \cdot 7 \mathrm{H}_{2} \mathrm{O}\right)$, respectivamente. Como direcionador de estrutura foi utilizado o copolímero tribloco Pluronic P$123\left((\mathrm{PEO})_{20}(\mathrm{PPO})_{70}(\mathrm{PEO})_{20}\right)(\mathrm{BASF})$. A síntese foi realizada com $2 \mathrm{~g}$ de P-123, dissolvido em $10 \mathrm{~mL}$ de etanol anidro $(99,9 \%)$. Os precursores foram solubilizados em mais $10 \mathrm{~mL}$ de etanol e adicionados à mistura com o polímero, permanecendo 


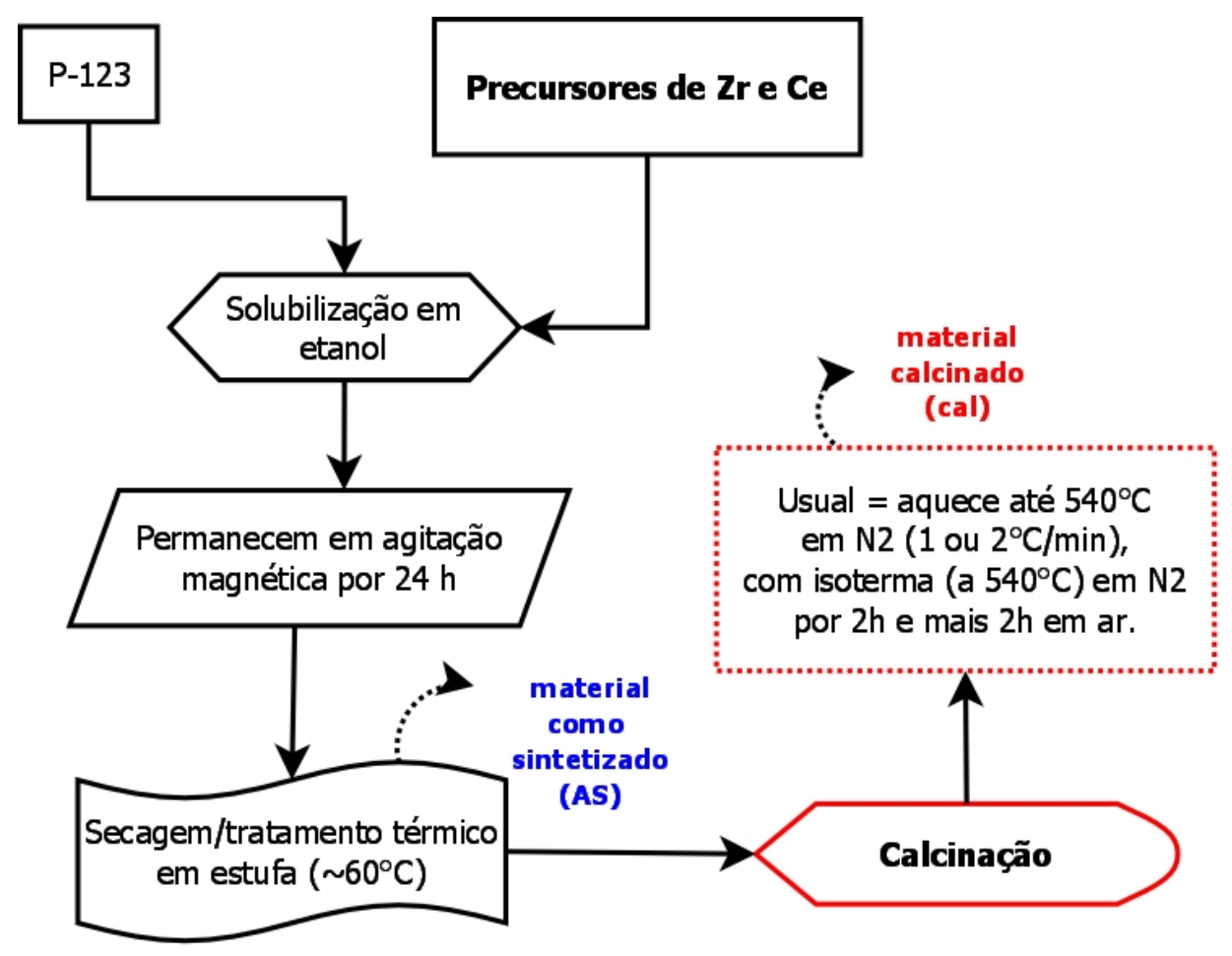

Figura 3.1: Diagrama esquemático de síntese de $\mathrm{ZrO}_{2}-\mathrm{CeO}_{2}$ porosa.

em agitação magnética por 24 horas. Após a agitação, a mistura foi colocada na estufa a $60^{\circ} \mathrm{C}$ para tratamento térmico, até a evaporação total do solvente (secagem da amostra).

- Método cloreto anidro Para esse método, foram testados precursores anidros para aumentar a capacidade de hidrólise durante a síntese, o polímero Pluronic P-123 foi solubilizado em etanol, então os precursores, $\mathrm{ZrCl}_{4}$ e $\mathrm{CeCl}_{3}$ foram adicionados sob agitação magnética. Como os precursores anidro e etanol anidro reagem em contato com água, uma primeira síntese teste com $\mathrm{x}=50$ foi feita sob atmosfera inerte de $\mathrm{N}_{2}$, dentro de uma glove box. Após 4 horas de agitação, $2 \mathrm{~mL}$ de água foram adicionados à mistura para que ocorresse a reação de hidrólise (para $\mathrm{x}=50$ ). No entanto, mesmo após 1 hora de agitação a reação não foi observada, uma vez que não houve evidência de formação de precipitado, sugerindo a não formação de compostos óxido-hidróxido, como se esperava. Como não foi observada uma melhora em relação à hidrólise do material, a síntese seguinte com $\mathrm{x}=90$ foi feita sem a utilização da glove box. Da mesma forma como nas sínteses anteriores, a amostra foi colocada na placa de Petri para tratamento térmico a $60^{\circ} \mathrm{C}$ na estufa, na presença de vapor de água, até a evaporação total do solvente. 
- Método nitrato Com o intuito de testar a influência do precursor na formação da estrutura ordenada, foi realizada uma síntese com precursores de zircônia e céria a base de nitratos, respectivamente $\mathrm{ZrO}\left(\mathrm{NO}_{3}\right)_{2} \cdot 6 \mathrm{H}_{2} \mathrm{O}$ e $\mathrm{Ce}\left(\mathrm{NO}_{3}\right)_{3} \cdot 6 \mathrm{H}_{2} \mathrm{O}$, $\operatorname{com} \mathrm{x}=90$. A rota de síntese foi a mesma empregada nos métodos anteriores, onde o polímero P-123 e os precursores de Zr e Ce foram solubilizados separadamente em etanol. Em seguida, a solução com P-123 foi adicionada à outra e a mistura permaneceu em agitação magnética por 24 horas. O tratamento térmico para promover a hidrólise na presença do vapor de água foi feita em estufa a $60^{\circ} \mathrm{C}$ até a evaporação total do solvente (secagem da amostra).

- Método solução supersaturada De forma a aumentar a espessura das paredes, os precursores de zircônio e cério utilizados no método nitrato $\left(\mathrm{ZrO}\left(\mathrm{NO}_{3}\right)_{2} \cdot 6 \mathrm{H}_{2} \mathrm{O}\right.$ e $\left.\mathrm{Ce}\left(\mathrm{NO}_{3}\right)_{3} \cdot 6 \mathrm{H}_{2} \mathrm{O}\right)$, foram medidos na proporção de $90 \% \mathrm{CeO}_{2}(\mathrm{x}=90)$ e misturados em acetona, pois os precursores de nitrato são solúveis em etanol e água. A amostra como sintetizada pelo método cloreto anidro com $90 \%$ de céria foi adicionada à solução com os precursores de nitrato e a mistura foi agitada manualmente até se obter uma solução homogênea. Essa mistura foi tampada e seca em estufa a $50^{\circ} \mathrm{C}$.

- Sínteses com silício Afim de aumentar a rigidez mecânica e melhorar propriedades texturais das amostras sintetizadas, foi desenvolvida uma síntese de $\mathrm{ZrO}_{2}-\mathrm{x} \% \mathrm{CeO}_{2}$ (utilizando $\mathrm{ZrCl}_{4}$ e $\mathrm{CeCl}_{3}$ ) com baixa quantidade de $\mathrm{Si}$ (TEOS, tetraetilortosilicato, como precursor de silício). São o método híbrido ( $\mathrm{x}=90 \mathrm{e}$ $10 \%$ de $\mathrm{Si})$, método paliçada $(\mathrm{x}=90,10$ e $30 \%$ de $\mathrm{Si})$ e método paliçada com temperatura de síntese de $40^{\circ} \mathrm{C}(\mathrm{x}=90$ e $30 \%$ de $\mathrm{Si})$.

No Método híbrido testou-se a incorporação de todos os precursores juntamente ao polímero Pluronic-P123 (2g), que foi solubilizado em 10mL de etanol, os precursores foram pesados na proporção de $90 \%$ de Ce e solubilizados em mais $10 \mathrm{~mL}$ de etanol. O precursor de silício foi adicionado gota a gota, onde $\mathrm{V}_{\text {TEOS }}=0,15 \mathrm{~mL}$, o correspondente a $10 \%$ molar, tal que em solução de $1 \mathrm{~mol}$, tem-se $0,1 \mathrm{~mol}$ de Si e $0,9 \mathrm{~mol}$ de $\mathrm{Zr}$ e Ce. Para essa proporção, $1 \mathrm{~mL}$ de $\mathrm{HCl}$ $(2 \mathrm{~mol} / \mathrm{L})$ foi adicionado à solução sob agitação magnética. A adição de $\mathrm{NH}_{4} \mathrm{OH}$ foi feita gota a gota para modificar o $\mathrm{pH}$, até $\mathrm{pH} \approx 3$, para promover maior agregação de sais ao polímero. A mistura permaneceu sob agitação magnética por 24 horas. Após o período de agitação a amostra foi colocada numa autoclave para tratamento hidrotérmico por 24 horas a $60^{\circ} \mathrm{C}$ em estufa. Esse tratamento é recomendado para agregar mais material às paredes [1. Depois desse tratamento a amostra foi seca em atmosfera com vapor de água $\left(\approx 60^{\circ} \mathrm{C}\right)$.

No Método paliçada, a principal diferença em relação ao método híbrido é a agitação prévia de TEOS e o Pluronic P-123 solubilizados em etanol e $\mathrm{HCl}$ $(2 \mathrm{~mol} / \mathrm{L})$ por 6 horas antes da adição dos precursores a base de Zr e Ce, e a base. 
O tratamento hidrotérmico em autoclave e a secagem foram feitos da mesma forma descrita no método híbrido. Foram realizadas sínteses com 0,1 e 0,3 mol de Si.

Para o Método paliçada com temperatura de síntese de $40^{\circ} \mathrm{C}$, o polímero pluronic P-123 e o precursor de Si, TEOS, foram solubilizados em etanol e $\mathrm{HCl}$ $(2 \mathrm{~mol} / \mathrm{L})$ e permaneceram sob agitação magnética por 15 horas a $40^{\circ} \mathrm{C}$. Após esse período de agitação, os precursores de $\mathrm{Zr}$ e Ce foram solubilizados e adicionados à solução. A base foi adicionada de modo a obter um $\mathrm{pH}$ em torno de 3, e essa mistura permaneceu sob agitação magnética por mais 9 horas. No final desse processo, a amostra passou por tratamento hidrotérmico em autoclave a $100^{\circ} \mathrm{C}$ por 48 horas. Após o tratamento hidrotérmico a amostra foi seca em vapor de água $\left(\approx 60^{\circ} \mathrm{C}\right)$.

A tabela 3.1 contém todas as amostras desse trabalho separadas por sigla, método e caracterizações realizadas. Todas as amostras antes ao processo de calcinação para a remoção do polímero foram denominadas com a sigla AS (AS = "as-synthesised", como sintetizadas). As sínteses e análises dos resultados que serão apresentados contaram com a colaboração da Profa. Dra. Tereza S. Martins (UNIFESP - Diadema). 
Tabela 3.1: Tabela com sigla, método de síntese e caracterização para as amostras sintetizadas nesse trabalho.

\begin{tabular}{|c|c|c|}
\hline Amostras & $\begin{array}{l}\text { Método de } \\
\text { Sintese }\end{array}$ & Caracterização Realizada \\
\hline $\mathrm{Zr50Ce}$ & & SAXS - amostras AS \\
\hline $\mathrm{Zr70Ce}$ & Cloreto & SAXS - calcinação $\left(540^{\circ} \mathrm{C}\right)$ \\
\hline $\mathrm{Zr90Ce}$ & Hidratado & SAXS - tratamento térmico $\left(350^{\circ} \mathrm{C}\right.$, a vácuo $)$ \\
\hline & & SAXS - amostras AS \\
\hline Zr50CeAN & & SAXS - in-situ LNLS $\left(25^{\circ} \mathrm{C}\right.$ a $\left.540^{\circ} \mathrm{C}\right)$ \\
\hline \multirow[t]{3}{*}{$\mathrm{Zr90CeAN}$} & Cloreto & XRD no LNLS - amostras calcinadas \\
\hline & Anidro & $\mathrm{BET}$ - amostras calcinadas $\left(540^{\circ} \mathrm{C}\right)$ \\
\hline & & SAXS/XRD - trat. térmico $\left(400^{\circ} \mathrm{C}, 2 \mathrm{~h}\right.$ em ar $)$ \\
\hline \multirow{4}{*}{$\begin{array}{l}\text { Zr90Ce- } \\
\text { SupSat }\end{array}$} & & SAXS - amostras AS \\
\hline & Solução & SAXS - trat. térmico $\left(300^{\circ} \mathrm{C}\right.$ em ar $)$ \\
\hline & Supersaturada & SAXS - calcinação $\left(540^{\circ} \mathrm{C}\right)$ \\
\hline & & $\mathrm{XRD}$ - calcinada $\left(540^{\circ} \mathrm{C}\right)$ \\
\hline \multirow{4}{*}{ Zr90Cenit } & & SAXS - amostra AS \\
\hline & Nitrato & SAXS - calcinada $\left(540^{\circ} \mathrm{C}\right)$ \\
\hline & & $\mathrm{XRD}$ - calcinada $\left(540^{\circ} \mathrm{C}\right)$ \\
\hline & & BET - calcinada $\left(540^{\circ} \mathrm{C}\right)$ \\
\hline \multirow{3}{*}{ Zr90CeH10 } & & SAXS - amostra AS \\
\hline & Híbrido & SAXS - calcinada $\left(540^{\circ} \mathrm{C}\right)$ \\
\hline & $(10 \% \mathrm{Si})$ & BET - calcinada $\left(540^{\circ} \mathrm{C}\right)$ \\
\hline \multirow{5}{*}{$\begin{array}{l}\text { Zr90CeP10 } \\
\text { Zr90CeP30 }\end{array}$} & & SAXS - amostra AS \\
\hline & Paliçada & SAXS - calcinada $\left(540^{\circ} \mathrm{C}\right)$ \\
\hline & $(10 \% \mathrm{Si})$ & $\mathrm{XRD}$ - calcinada $\left(540^{\circ} \mathrm{C}\right)$ \\
\hline & $(30 \% \mathrm{Si})$ & BET - calcinada $\left(540^{\circ} \mathrm{C}\right)$ \\
\hline & & $\begin{array}{l}\text { SAXS /XRD - trat. tér. }\left(300,350,400^{\circ} \mathrm{C} \text { em } N_{2}\right) \\
\text { SAXS/XRD - trat. tér. }\left(400^{\circ} \mathrm{C}, 2 \mathrm{~h} \mathrm{em} \mathrm{ar}\right)\end{array}$ \\
\hline \multirow{3}{*}{ Zr90CeP30T } & & SAXS - amostras AS \\
\hline & Paliçada com & SAXS - calcinada $\left(540^{\circ} \mathrm{C}\right)$ \\
\hline & $\begin{array}{l}\text { Temperatura } \\
\text { de } 40^{\circ} \mathrm{C}\end{array}$ & $\begin{array}{c}\text { SAXS - calcinada }\left(540^{\circ} \mathrm{C} 2 \mathrm{~h} \text { em ar }\right) \\
\text { XRD - calcinada }\left(540^{\circ} \mathrm{C}\right)\end{array}$ \\
\hline
\end{tabular}

\subsection{Resultados}

\subsubsection{Método cloreto hidratado}

Os resultados preliminares de SAXS para o método cloreto hidratado foram realizados num gerador de raios X de ânodo rotatório com geometria de feixe linha, detetor 
unidimensional e menor intensidade. Dessa forma foi obtida uma curva de SAXS com apenas um pico de difração, o que não permitiu determinar a simetria do sistema.

De maneira a aumentar a hidrólise dos precursores e diminuir o pH do meio reacional, novas amostras foram sintetizadas com os mesmos precursores. Nessa nova síntese foram adicionados $\approx 2 \mathrm{~mL}$ de água à mistura obtida após três horas de agitação, num total de 24 horas de agitação, seguida por um tratamento térmico na presença de vapor de água. Esse tratamento mostrou ser uma alternativa positiva para produzir um material com uma estrutura mais bem ordenada. Os resultados das amostras sintetizadas com adição de água, encontram-se na figura 3.2. Essas medidas foram realizadas no equipamento Nanostar, o que permitiu identificar a estrutura formada como lamelar (reflexões $l-10$ e $l-20$, com $l$ para lamelar).

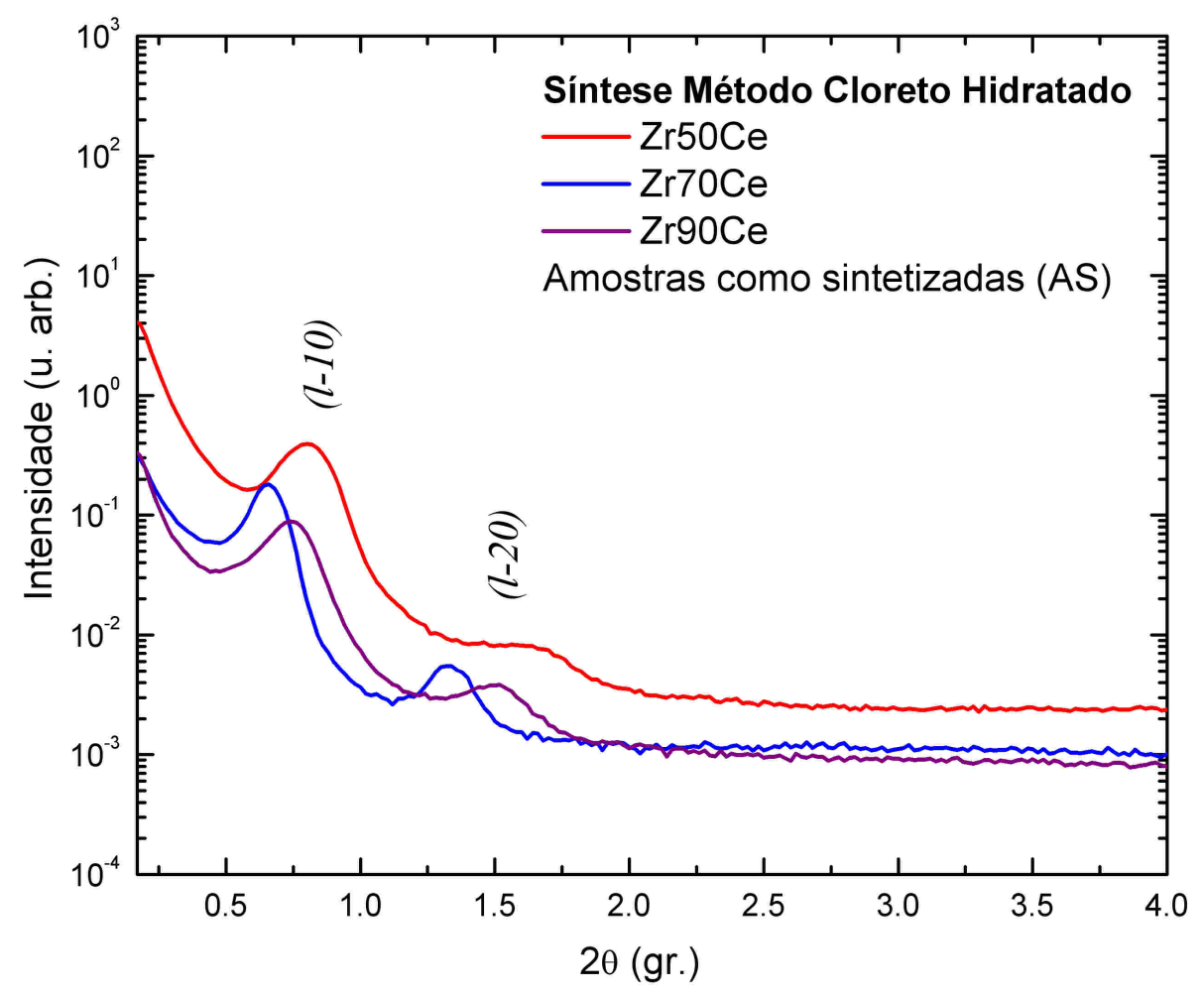

Figura 3.2: Resultados de SAXS para amostras como sintetizadas (AS), para o método cloreto hidratado com concentração molar de 50, 70 e $90 \%$ de $\mathrm{CeO}_{2}$.

Na tabela 3.2 são mostrados os parâmetros de rede (a) e a área sob os picos das 
reflexões $l-10$ e $l$-20 das amostras como sintetizadas.

Tabela 3.2: Área das reflexões $l-10$ e $l-20\left(\mathrm{~A}_{l-10+l-20}\right)$, a área total sob os picos $\left(\mathrm{A}_{\text {total }}\right)$, a fração ordenada $\left(\mathrm{f}_{\text {ord }}\right)$ e o parâmetro de rede (a) para as amostras sintetizadas pelo método cloreto hidratado (AS).

\begin{tabular}{lcccc}
\hline Amostras & $\begin{array}{c}\mathbf{A}_{l-10+l-20} \\
\text { (u. arb. })\end{array}$ & $\begin{array}{c}\mathbf{A}_{\text {total }} \\
\text { (u. arb. })\end{array}$ & $\mathbf{f}_{\text {ord }}$ & $\begin{array}{c}\text { a } \\
(\mathrm{nm})\end{array}$ \\
\hline Zr50Ce & 60 & 116 & 0,52 & $10,90(4)$ \\
Zr70Ce & 23 & 40 & 0,57 & $13,28(2)$ \\
Zr90Ce & 15 & 27 & 0,55 & $11,78(5)$ \\
\hline
\end{tabular}

As áreas das reflexões $l-10$ e $l-20\left(\mathrm{~A}_{l-10+l-20}\right)$ foram calculadas após o fundo de espalhamento ser retirado da curva de SAXS, fazendo um ajuste linear sob os picos. A área total $\left(\mathrm{A}_{\text {total }}\right)$ sob os picos foi calculada da curva de SAXS sem retirar o fundo e, a fração ordenada foi definida como $f_{o r d}=A_{l-10+l-20} / A_{\text {total }}$. Essa fração ordenada, não representa um fator quantitativo de ordenamento, mas um parâmetro relativo e qualitativo para comparação dos resultados obtidos. O parâmetro de rede (a) das reflexões foram calculados através da equação 2.6 e a incerteza é dada pela média dos valores obtidos dos dois picos de difração.

Os resultados de SAXS mostraram que todas as amostras possuíam um ordenamento similar, independente do conteúdo de Ce. Uma maior variação de densidade eletrônica parede/polímero $\left(\mathrm{A}_{\text {total }}\right)$ foi observada para a amostra com menor conteúdo de $\mathrm{Ce}(\mathrm{Zr} 50 \mathrm{Ce})$, o que indica maior agregação ao polímero dos radicais contendo Zr. Uma variação não sistemática do parâmetro de rede como função da concentração de Ce foi obtida.

A calcinação para remover o polímero do material como sintetizado foi feita aquecendo a amostra em atmosfera inerte de $\mathrm{N}_{2}$ até $540^{\circ} \mathrm{C}$ a $2^{\circ} \mathrm{C} / \mathrm{min}$, seguida por uma isoterma de 2 horas em $\mathrm{N}_{2}$ e mais 2 horas em ar. O resfriamento foi feito com o desligamento do forno. Após esse processo os picos de difração a baixo ângulo desapareceram, revelando a perda de estrutura ordenada, como esperado para um sistema lamelar, mas mantendo uma porosidade com poros não correlacionados espacialmente.

Um tratamento térmico à menor temperatura de 250,300 e $350^{\circ} \mathrm{C}$ em vácuo, mostrou que até a temperatura de $300^{\circ} \mathrm{C}$ não é possível remover todo o material carbonáceo presente nas amostras, como pode ser constatato pela coloração escura do material final, que também perdeu o ordenamento lamelar original.

Em seguida, a adição à síntese de uma base $\left(\mathrm{NH}_{4} \mathrm{OH}\right)$ foi testada com o objetivo de formar um precipitado insolúvel e retirar o polímero por extração por solvente a menor temperatura, ou seja, por um método menos destrutivo que a calcinação até 
$540^{\circ} \mathrm{C}$. A base foi adicionada durante o processo de síntese e também após o material passar por tratamento térmico. Nesse último caso o pó foi solubilizado em uma pequena quantidade de água. Nenhuma das amostras analisadas por SAXS apresentou uma estrutura ordenada, portanto, esses resultados excluíram essa alternativa de síntese para produzir um material mais poroso, visto que não houve uma indicação da agregação dos precursores ao redor do polímero.

\subsubsection{Método cloreto anidro}

A síntese com precursores anidros foi feita com o objetivo de formar alcoóxidos, uma vez que estes, na presença de água formam óxidos, por hidrólise.

Os resultados de SAXS obtidos no LNLS para as amostras encontram-se na figura 3.3 e, a tabela 3.3 apresenta a área dos picos $l-10$ e $l$-20 (onde $A_{l-20} \approx 0$ ) e o parâmetro de rede $(\mathrm{a})$.

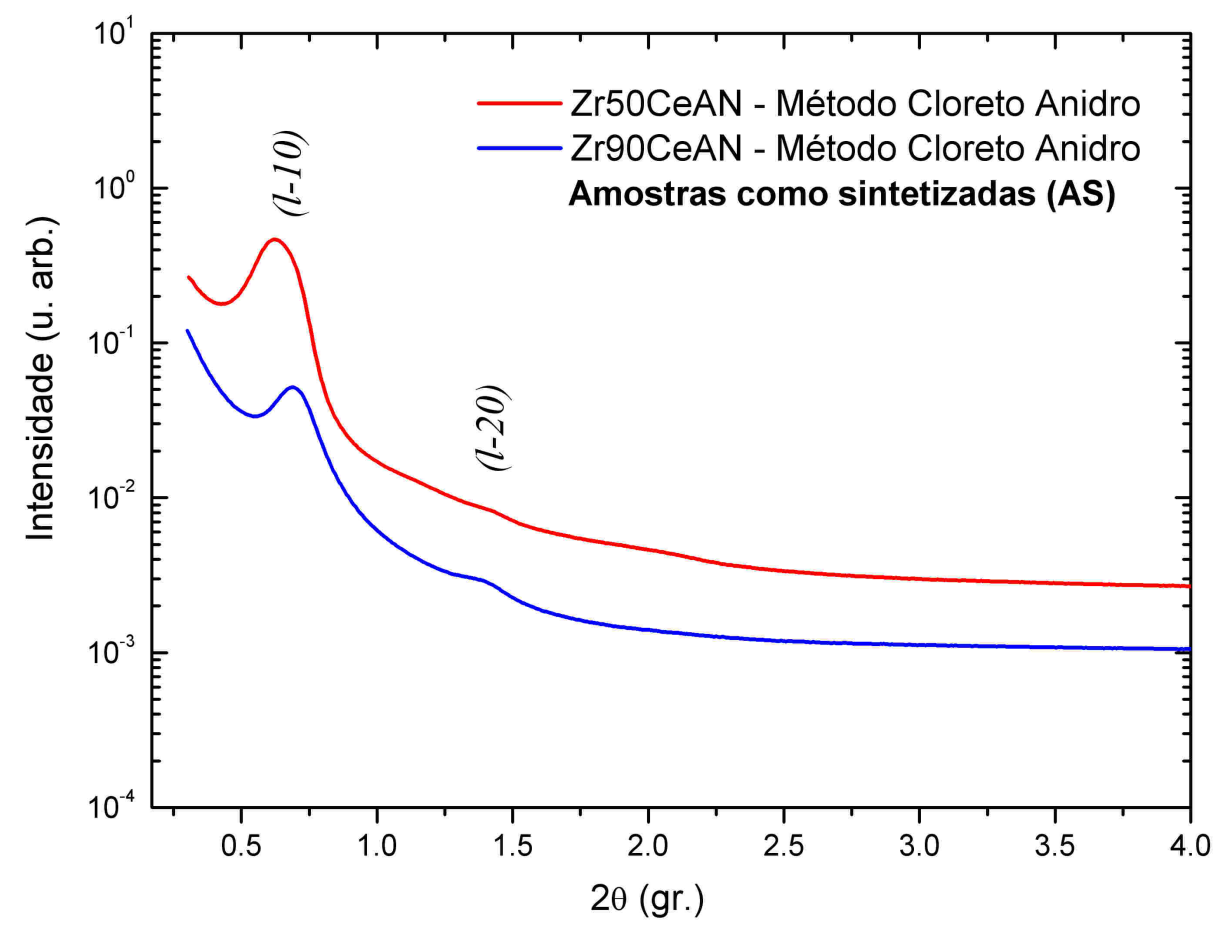

Figura 3.3: Resultados de SAXS para amostras como sintetizadas pelo método cloreto anidro para a concentração molar de 50 e $90 \%$ de $\mathrm{CeO}_{2}$ (LNLS). 
Tabela 3.3: Área das reflexões $l-10$ e $l$-20 $\left(\mathrm{A}_{l-10+l-20}\right)$, a área total sob os picos $\left(\mathrm{A}_{\text {total }}\right)$, a fração ordenada $\left(\mathrm{f}_{\text {ord }}\right)$ e o parâmetro de rede (a) para as amostras sintetizadas pelo método cloreto anidro (AS) (LNLS).

\begin{tabular}{ccccc}
\hline Amostras & $\begin{array}{c}\mathbf{A}_{l-10+l-20} \\
\text { (u. arb. })\end{array}$ & $\begin{array}{c}\mathbf{A}_{\text {total }} \\
\text { (u. arb. })\end{array}$ & $\mathbf{f}_{\text {ord }}$ & $\begin{array}{c}\mathbf{a} \\
(\mathrm{nm})\end{array}$ \\
\hline Zr50Ce & 81 & 115 & 0,70 & 14,1 \\
Zr90Ce & 5 & 18 & 0,28 & 12,7 \\
\hline
\end{tabular}

Os resultados de SAXS das amostras preparadas pelo método cloreto anidro (AS) também mostraram uma maior variação de densidade eletrônica parede/polímero, e maior fração ordenada do que obtido anteriormente para a amostra com menor conteúdo de Ce. Nessa síntese a fração ordenada foi inferior para o maior conteúdo de Ce.

Para avaliar os efeitos da temperatura de calcinação nas amostras, um estudo de SAXS com variação in-situ de temperatura e radiação sincrotrônica foi realizado, onde as amostras de concentração molar de 50 e $90 \%$ (método cloreto anidro) foram analisadas.

\subsubsection{Experimento de SAXS com temperatura para estudo da calcinação in-situ no LNLS}

O experimento de calcinação in-situ através da análise de SAXS como função da temperatura foi realizado no LNLS para avaliar as modificações estruturais durante o processo de remoção do polímero do material. Os dados foram obtidos na linha SAXS2 (projeto D11A/SAXS1-7124) com um cristal de Si(111) como monocromador e $\lambda=0,1608 \mathrm{~nm}$. A distância amostra-detetor foi de $\approx 800 \mathrm{~mm}$ e foi utilizado um detector bidimensional MAR-CCD.

A programação do forno consistiu de uma rampa de $1^{\circ} \mathrm{C} / \mathrm{min}$, com uma isoterma a $540^{\circ} \mathrm{C}$. O forno utilizado no experimento foi mantido em vácuo de bomba mecânica $\left(\approx 10^{-2}\right.$ Torr $)$. Os dados foram normalizados pelo fator de atenuação e a intensidade total do feixe. Os resultados das medidas para a amostra de $50 \%$ e $90 \%$ de céria, sintetizadas pelo método cloreto anidro, encontram-se nas figuras 3.4 a 3.5 .

A intensidade do pico de difração da reflexão $l-10$, da amostra com $50 \%$ de $\mathrm{CeO}_{2}$ é apresentada no gráfico da figura $3.4(\mathrm{~b})$ e decresce com o aumento da temperatura, até $\mathrm{T}_{L} \approx 300^{\circ} \mathrm{C}$, quando não é mais distinguida do fundo de espalhamento. Essa temperatura limite $\left(\mathrm{T}_{L}\right)$, até a qual o ordenamento do sistema é preservado, foi analisada nas sínteses subsequentes. Ou seja, a decomposição e remoção do polímero são acompanhadas pela perda contínua da estrutura ordenada, como previsto para sistemas 
lamelares.

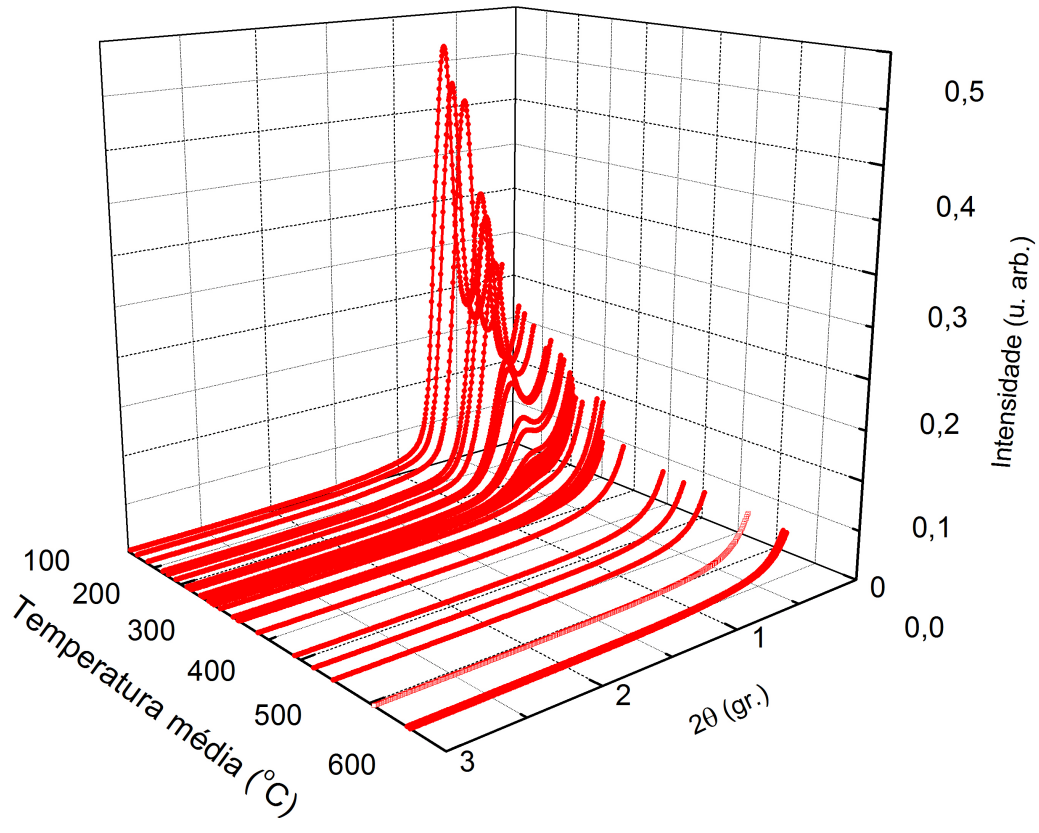

(a) Resultados de SAXS em função da temperatura.

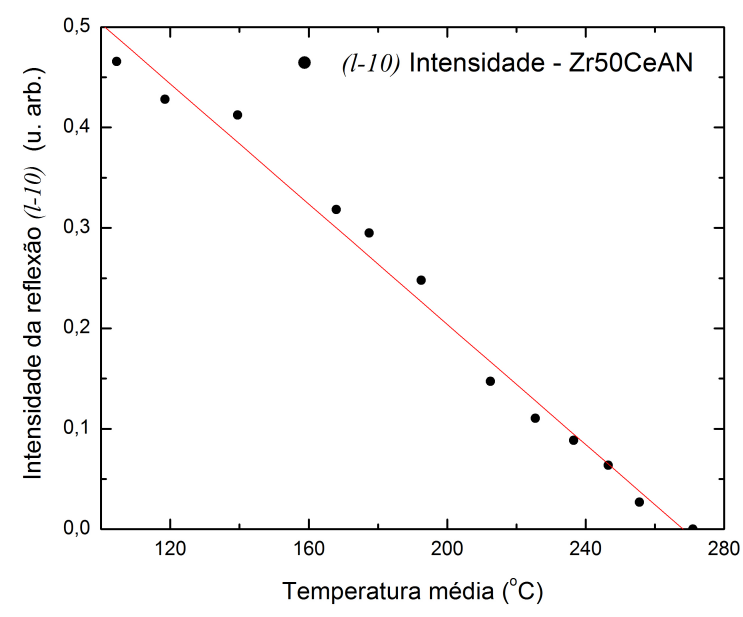

(b) Gráfico da intensidade da reflexão $l-10$.

Figura 3.4: Resultados do experimento de SAXS com calcinação in-situ para a amostra de $\mathrm{ZrO}_{2} / \mathrm{CeO}_{2}$ com $50 \%$ de $\mathrm{CeO}_{2}$ (LNLS). 


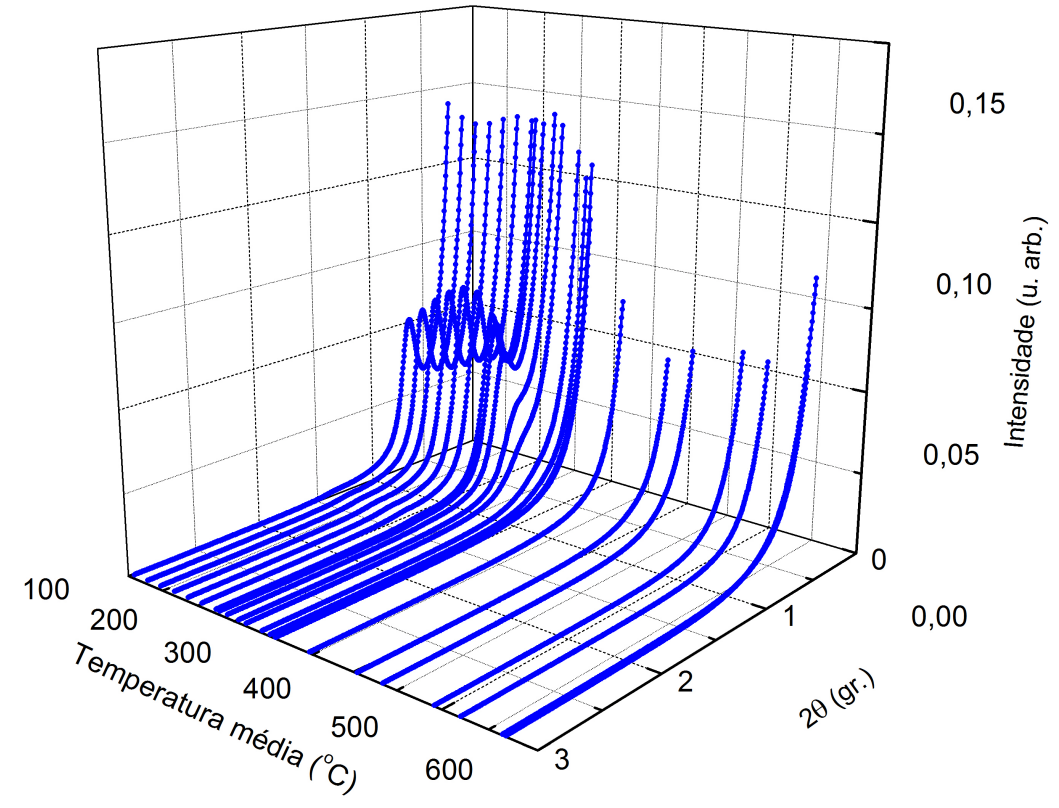

(a) Resultados de SAXS em função da temperatura.

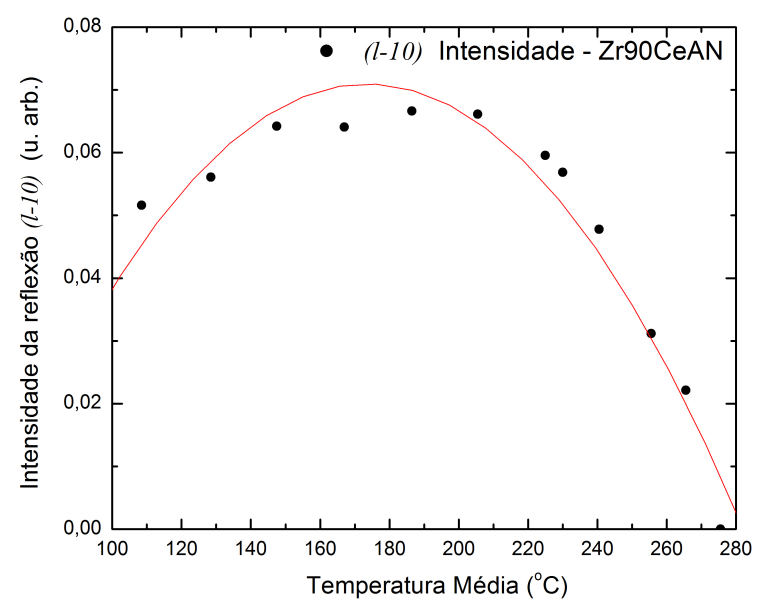

(b) Gráfico da intensidade da reflexão l-10.

Figura 3.5: Resultados do experimento de SAXS com calcinação in-situ para a amostra de $\mathrm{ZrO}_{2} / \mathrm{CeO}_{2}$ com $90 \%$ de $\mathrm{CeO}_{2}$ (LNLS).

A tabela 3.4 apresenta os dados para o parâmetro de rede e área sob a reflexão 
l-10 (uma vez que $\mathrm{A}_{l-20} \approx 0$ ) em função da temperatura de tratamento térmico para a amostra de $50 \%$ de $\mathrm{CeO}_{2}$.

A medida que o molde é removido observou-se uma retração da estrutura, geralmente atribuída à densificação das paredes, comum em sistemas porosos a base de sílica[8].

Tabela 3.4: Área da reflexão $l-10\left(\mathrm{~A}_{l-10}\right)$ e parâmetro de rede (a) para a amostra Zr50CeAN-AS sintetizada pelo método cloreto anidro em função da temperatura (LNLS).

\begin{tabular}{ccc}
\hline $\begin{array}{c}\text { Temperatura média } \\
\left({ }^{\circ} \mathrm{C}\right)\end{array}$ & $\begin{array}{c}\mathbf{A}_{l-10} \\
(\text { u. arb. })\end{array}$ & $\begin{array}{c}\mathbf{a} \\
(\mathrm{nm})\end{array}$ \\
\hline 104,5 & 63 & 14,6 \\
118,5 & 58 & 14,6 \\
139,5 & 56 & 14,5 \\
168,0 & 43 & 14,4 \\
177,5 & 40 & 14,3 \\
192,5 & 33 & 14,2 \\
212,5 & 16 & 14,0 \\
220,5 & 9 & 14,0 \\
236,5 & 6 & 14,0 \\
246,5 & 2 & 14,0 \\
260,5 & $2 \cdot 10^{-2}$ & 14,0 \\
\hline
\end{tabular}

Para a concentração de $90 \%$ de $\mathrm{CeO}_{2}$ (figuras 3.5(a) e 3.5(b) há um aumento na intensidade da reflexão $l-10$, o que é esperado, uma vez que a decomposição do polímero aumenta o contraste de densidade eletrônica entre o molde e as paredes. Por volta de $150^{\circ} \mathrm{C}$ a intensidade da reflexão $l-10$ atinge um máximo, mas em torno de $300^{\circ} \mathrm{C}$ essa reflexão desaparece, mostrando o colapso da estrutura ordenada do sistema.

A tabela 3.5 apresenta os dados para o parâmetro de rede e área sob a reflexão l-10 (uma vez que $\mathrm{A}_{l-20} \approx 0$ ) em função da temperatura do tratamento térmico para a amostra de $90 \%$ de $\mathrm{CeO}_{2}$.

Diferentemente do comportamento do parâmetro de rede com a temperatura apresentado pela amostra com $50 \%$ de $\mathrm{CeO}_{2}$, nesse caso observou-se um pequeno aumento assintótico de $a$.

Comparativamente, a amostra com $90 \%$ de $\mathrm{CeO}_{2}$ apresentou uma estabilidade mecânica superior à de 50\%, frente à remoção do molde. Após o final do processo de medida ambas amostras mostraram curvas de SAXS típicas de sistemas porosos não ordenados. 
Tabela 3.5: Área da reflexão $l-10\left(\mathrm{~A}_{l-10}\right)$ e parâmetro de rede (a) para a amostras Zr90CeAN-AS sintetizada pelo método cloreto anidro em função da temperatura (LNLS).

\begin{tabular}{ccc}
\hline $\begin{array}{c}\text { Temperatura média } \\
\left({ }^{\circ} \mathrm{C}\right)\end{array}$ & $\begin{array}{c}\mathbf{A}_{l-10} \\
(\text { u. arb. })\end{array}$ & $\begin{array}{c}\mathbf{a} \\
(\mathrm{nm})\end{array}$ \\
\hline 108,5 & 3,9 & 13,2 \\
128,5 & 4,7 & 13,2 \\
147,5 & 5,4 & 13,2 \\
167,0 & 6,0 & 13,2 \\
186,5 & 6,3 & 13,2 \\
205,5 & 5,9 & 13,2 \\
225,5 & 4,7 & 13,3 \\
230,0 & 4,3 & 13,4 \\
240,5 & 2,9 & 13,4 \\
255,5 & 0,5 & 13,5 \\
265,5 & $7 \cdot 10^{-6}$ & 13,4 \\
\hline
\end{tabular}

A fim de avaliar a estrutura das paredes de zircônia-céria foi feito um estudo por XRD no LNLS, tendo em vista que a presença da fase tetragonal pode ser detetada com precisão através do uso de radiação síncrotron[26].

\subsubsection{Experimento de XRD no LNLS}

Em colaboração com o professor Prof. Dr. Diego G. Lamas e Prof. Dr. Rodolfo O. Fuentes (CINSO, Buenos Aires, Argentina), foram realizadas medidas de XRD para as amostras de 50 e $90 \%$ de $\mathrm{CeO}_{2}$ sintetizadas pelo método cloreto anidro. As medidas de difração foram realizadas na linha de XPD do LNLS (projeto D10B/XPD-2960). 


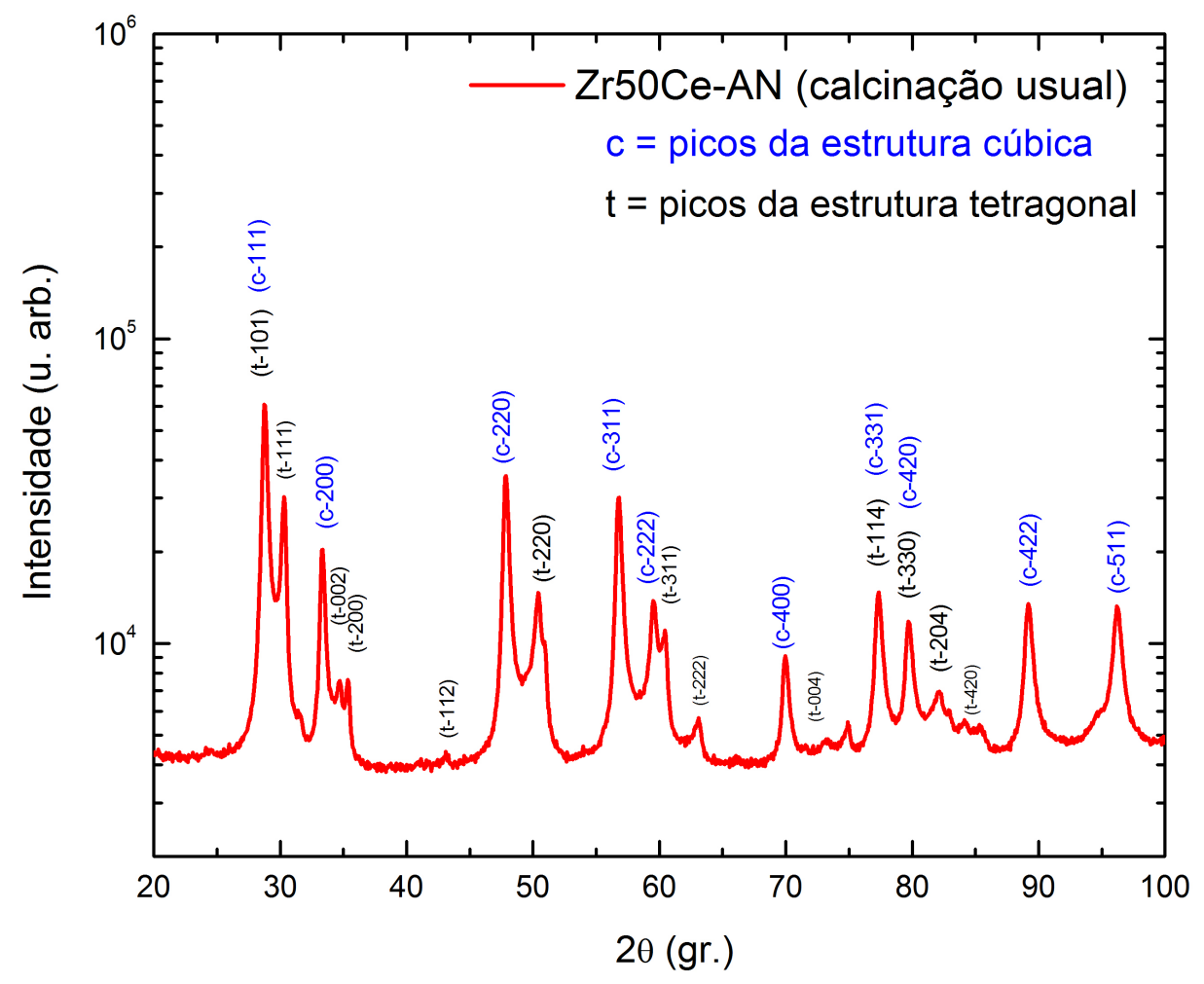

Figura 3.6: Resultados de XRD para a amostra de $\mathrm{ZrO}_{2} / \mathrm{CeO}_{2}$ com $50 \%$ de $\mathrm{CeO}_{2}$ (LNLS).

O comprimento de onda utilizado foi de $\lambda=0,15498 \mathrm{~nm}$. A configuração de alta intensidade (baixa resolução) foi escolhida, sem cristal analisador, com $2 \theta$ de $18^{\circ}$ a $102^{\circ}$ com um passo de $0.05^{\circ}$ e tempo de contagem de $3.0 \mathrm{~s} /$ passo.

Os resultados encontram-se nas figuras 3.6 e 3.7. Para a amostra com $50 \%$ de $\mathrm{CeO}_{2}$, a fase é mista com simetria cúbica e tetragonal, já para $90 \%$, a amostra possui paredes com fase única de simetria cúbica.

Esses resultados de XRD permitiram determinar que as próximas amostras a serem sintetizadas seriam com a concentração molar de $90 \%$ de céria, visto que essa concentração produz paredes cristalinas de fase única com simetria cúbica.

As isotermas de adsorção-dessorção de $\mathrm{N}_{2}$ para amostras sintetizadas com cloreto anidro encontram-se na figura 3.8, juntamente com a área superficial BET, similar para as duas amostras. As isotermas são características do tipo $\mathrm{H}_{3}$, ou seja, de amostras 


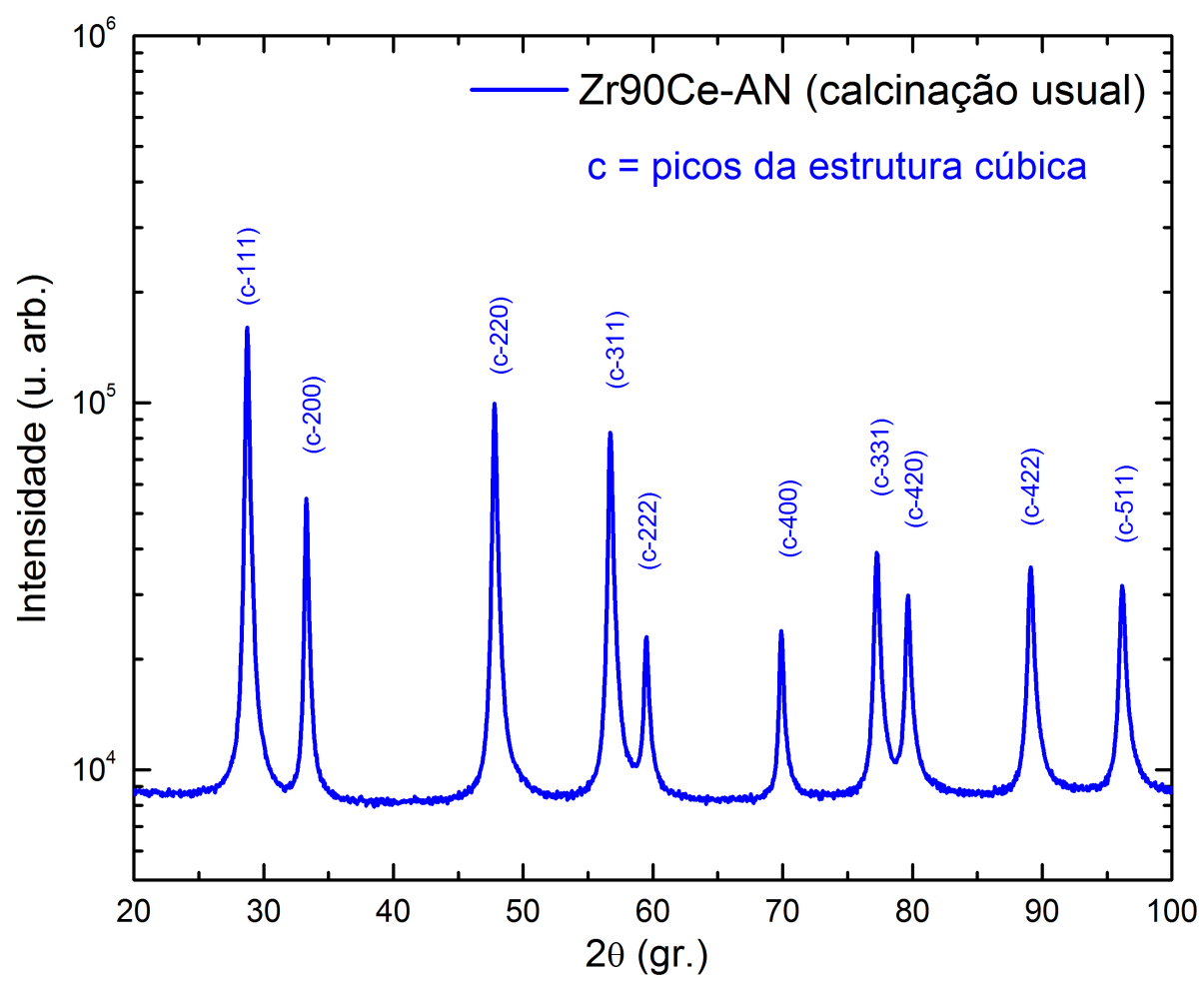

Figura 3.7: Resultados de XRD para a amostra de $\mathrm{ZrO}_{2} / \mathrm{CeO}_{2}$ com $90 \%$ de $\mathrm{CeO}_{2}$ LNLS).

com poros pequenos na forma de fendas, resultado consistente com a estrutura original do tipo lamelar. De acordo com o gráfico (fig. 3.8), a área superficial é igual para concentrações diferentes de céria. Para $90 \%$ de $\mathrm{CeO}_{2}$, o volume adsorvido é o dobro para $50 \%$. A isoterma de adsorção indica um formato de poro mais irregular para $50 \%$ de $\mathrm{CeO}_{2}$, pois a curva de dessorção se diferencia da curva de adsorção para valores próximos de $\mathrm{P} / \mathrm{P}_{0}=1$. 


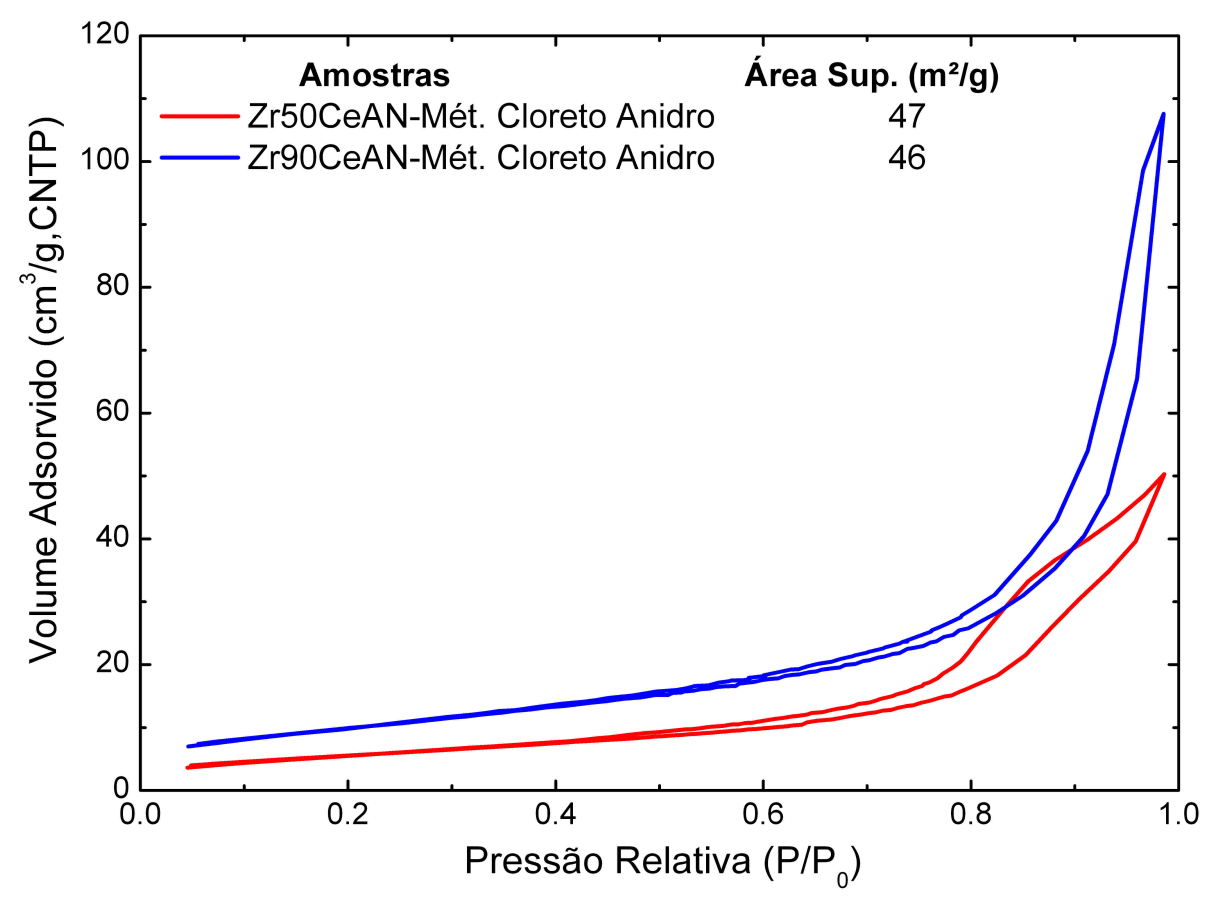

Figura 3.8: Resultados para as isotermas de adsorção-dessorção de $\mathrm{N}_{2}$ para as amostras com concentrações molares de $50 \%$ e $90 \%$ de $\mathrm{CeO}_{2}$ (método cloreto anidro).

A área superficial (BET) para a amostra Zr50CeAN é de $47 \mathrm{~m}^{2} / \mathrm{g}$ e para $\mathbf{Z r 9 0 C e A N}$ é de $46 \mathrm{~m}^{2} / \mathrm{g}$. Os resultados para a distribuição de tamanho de poros mostraram que essas amostras não possuem uma distribuição estreita de diâmetros, sendo, portanto, impossível atribuir um diâmetro médio de poros aos sistemas estudados.

\subsubsection{Método nitrato}

Os resultados de SAXS e XRD encontram-se nas figuras 3.9 e 3.10. 


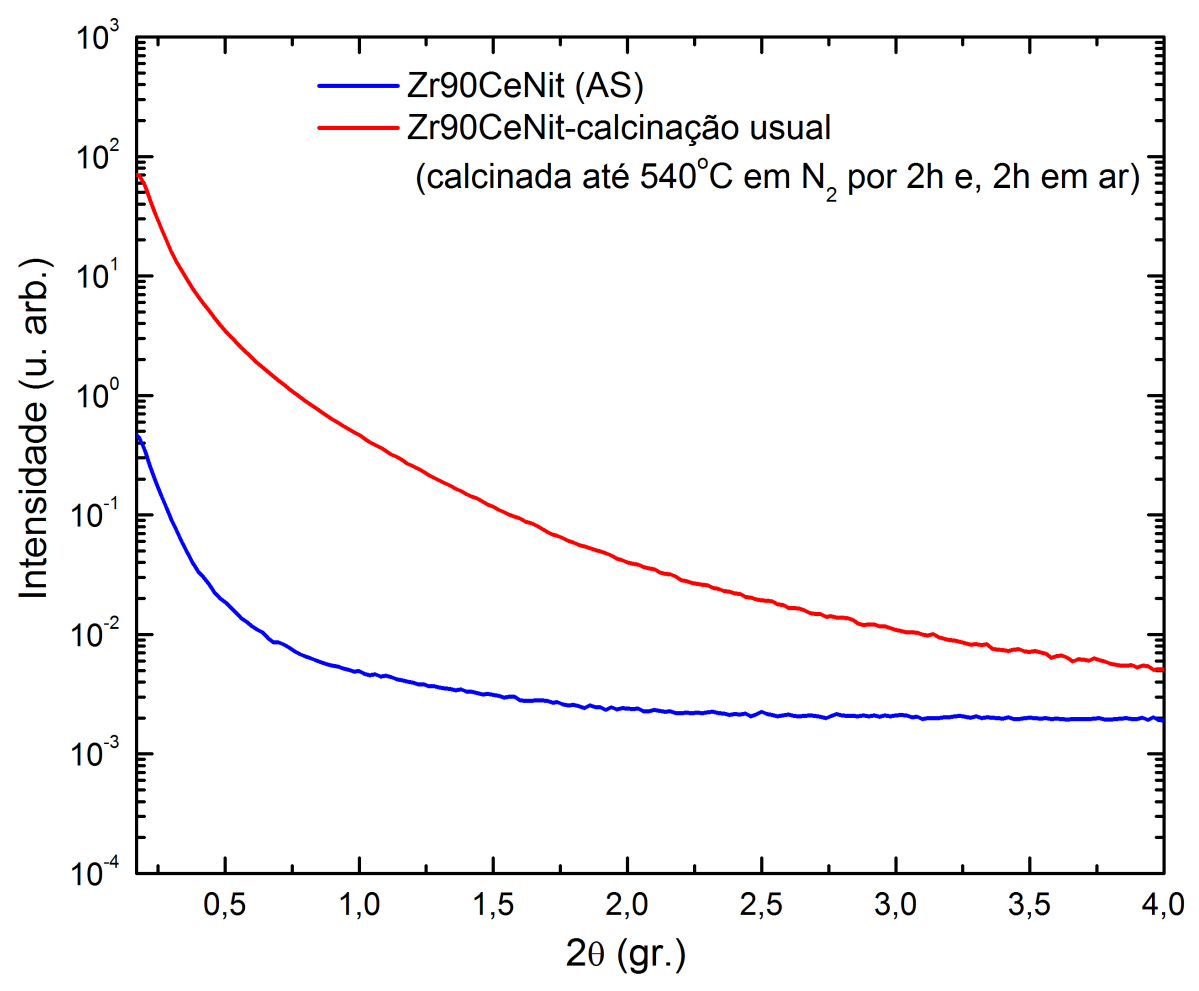

Figura 3.9: Resultados de SAXS para amostra de $\mathrm{ZrO}_{2} / \mathrm{CeO}_{2}$ com $90 \%$ de $\mathrm{CeO}_{2}$ (método nitrato).

A amostra como sintetizada não apresenta difração característica de um sistema ordenado e portanto, a substituição de precursores não induz a um melhor ordenamento do material para posterior remoção do molde. A não formação da estrutura ordenada pode ser relacionada ao $\mathrm{pH}$ do meio, maior do que na síntese com precursores a base de cloretos. Soluções mais ácidas são mais favoráveis à formação de sistemas micelares ordenados que utilizam direcionadores de estrutura neutros, como o Pluronic P-123.

A calcinação dessa amostra foi feita em forno tubular com rampa de $2{ }^{\circ} \mathrm{C} / \mathrm{min}$ até $540^{\circ} \mathrm{C}$ em atmosfera de $\mathrm{N}_{2}$, seguida por uma isoterma de 2 horas em $\mathrm{N}_{2}$ e mais 2 horas em ar. Os resultados de SAXS para a amostra após a calcinação também mostram a presença de poros não ordenados no material.

Os resultados de XRD da amostra calcinada, obtidos com fonte convencional, mostraram paredes formadas pela fase cúbica da zircônia-céria, como esperado, visto 


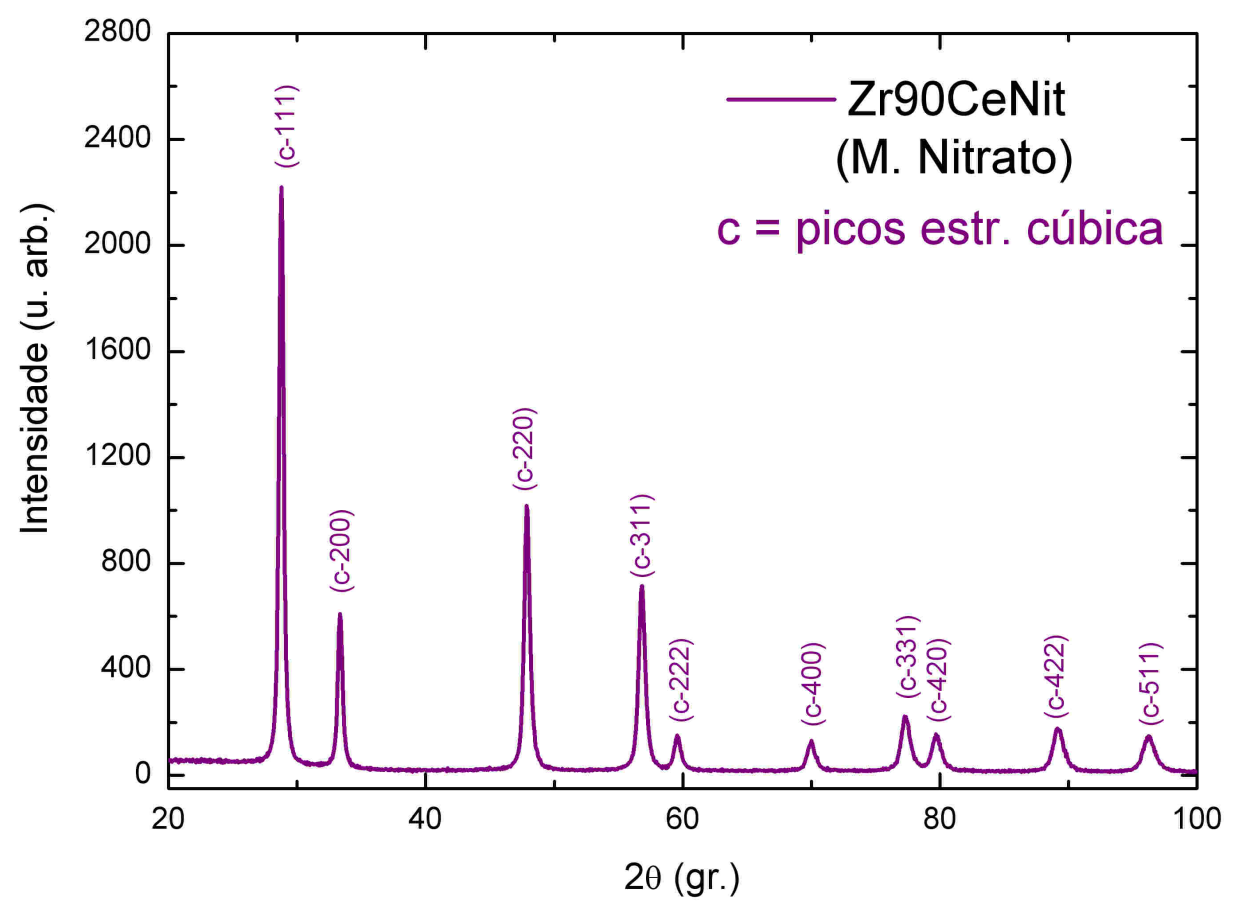

Figura 3.10: Resultados de XRD para amostra calcinada até $540^{\circ} \mathrm{C}$, de $\mathrm{ZrO}_{2} / \mathrm{CeO}_{2}$ com $90 \%$ de $\mathrm{CeO}_{2}$ (método nitrato).

que não há indicações da reflexão (112), em torno de $41^{\circ}$, da fase tetragonal no difratograma apresentado na figura 3.10 .

A isoterma de adsorção-dessorção de $\mathrm{N}_{2}$ para a amostra sintetizada com nitrato encontra-se na figura 3.11, juntamente com a área superficial BET.

A área superficial para a amostra Zr90Cenit, de $9 \mathrm{~m}^{2} / \mathrm{g}$, é 5 vezes inferior aos valores obtidos pelo método cloreto anidro, juntamente com o volume adsorvido, $\approx$ 20 vezes inferior ao método com a mesma concentração de céria. O que demonstra a melhor eficiência dos precursores cloretos, comparados aos de nitrato, para produzir um material com maior área superficial. A isoterma de adsorção também é do tipo $\mathrm{H}_{3}$, com poros pequenos em formato de fenda.

Os resultados para a distribuição de tamanho de poros não apresentaram uma distribuição estreita de diâmetros, portanto não foi possível determinar um diâmetro médio de poros para essa amostra. 


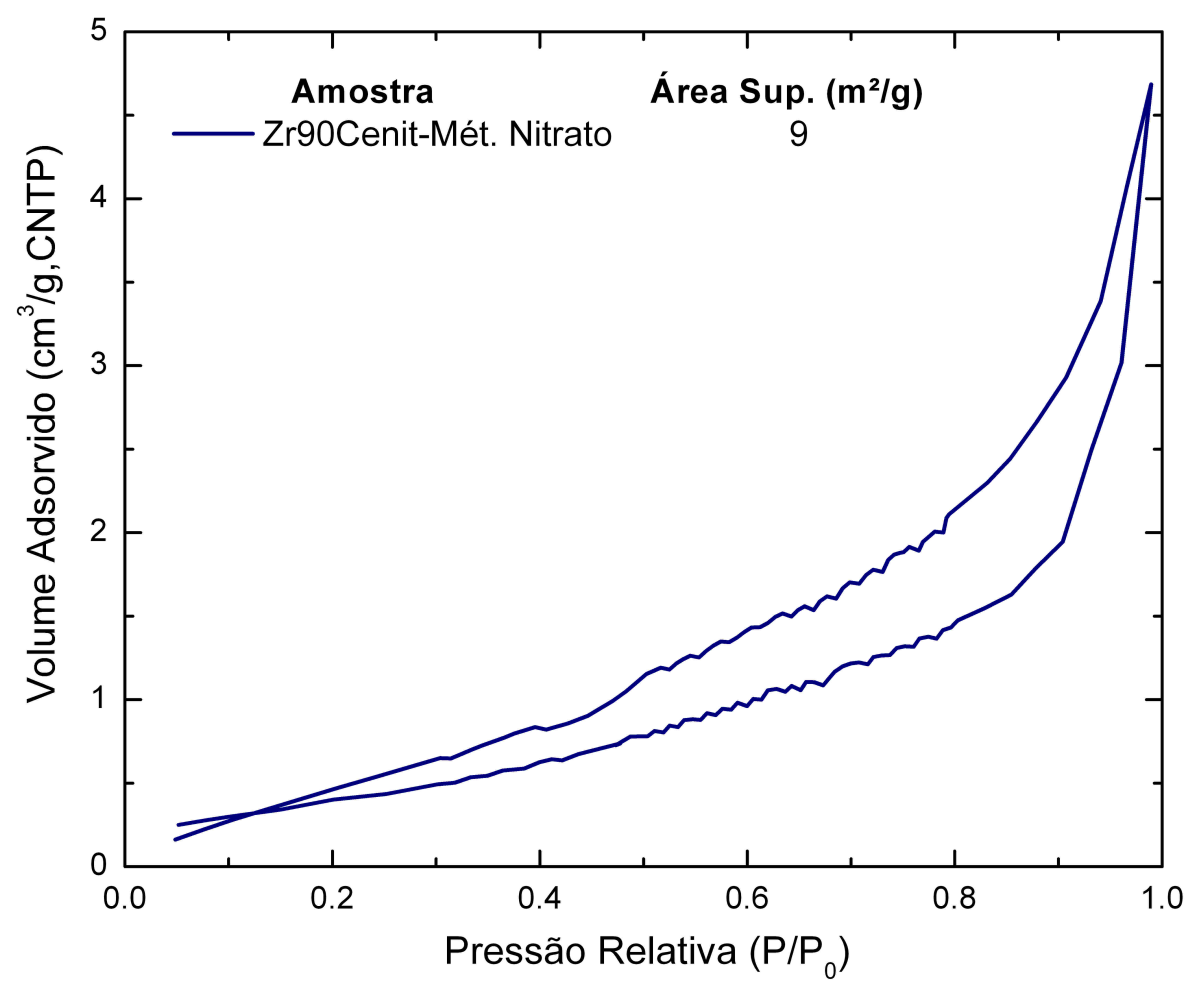

Figura 3.11: Resultados para a isoterma de adsorção-dessorção de $\mathrm{N}_{2}$ para a amostra com concentração molar de $90 \%$ de $\mathrm{CeO}_{2}$ (método nitrato).

\subsubsection{Método solução supersaturada}

Devido aos resultados anteriores que mostraram a perda da estrutura ordenada após a remoção do polímero com consequente diminuição de diâmetro de poros, foi testada uma alternativa para aumentar a espessura das paredes de uma amostra já sintetizada (Zr90CeAN). Parte da amostra passou por tratamento térmico até $300^{\circ} \mathrm{C}$ (temperatura limite) em ar com rampa de $1^{\circ} \mathrm{C} / \mathrm{min}$, e outra parte foi calcinada de forma usual até $540^{\circ} \mathrm{C}$ (fig. fig:sint).

Os resultados de SAXS encontram-se na figura 3.12 e XRD, na figura 3.13 . 


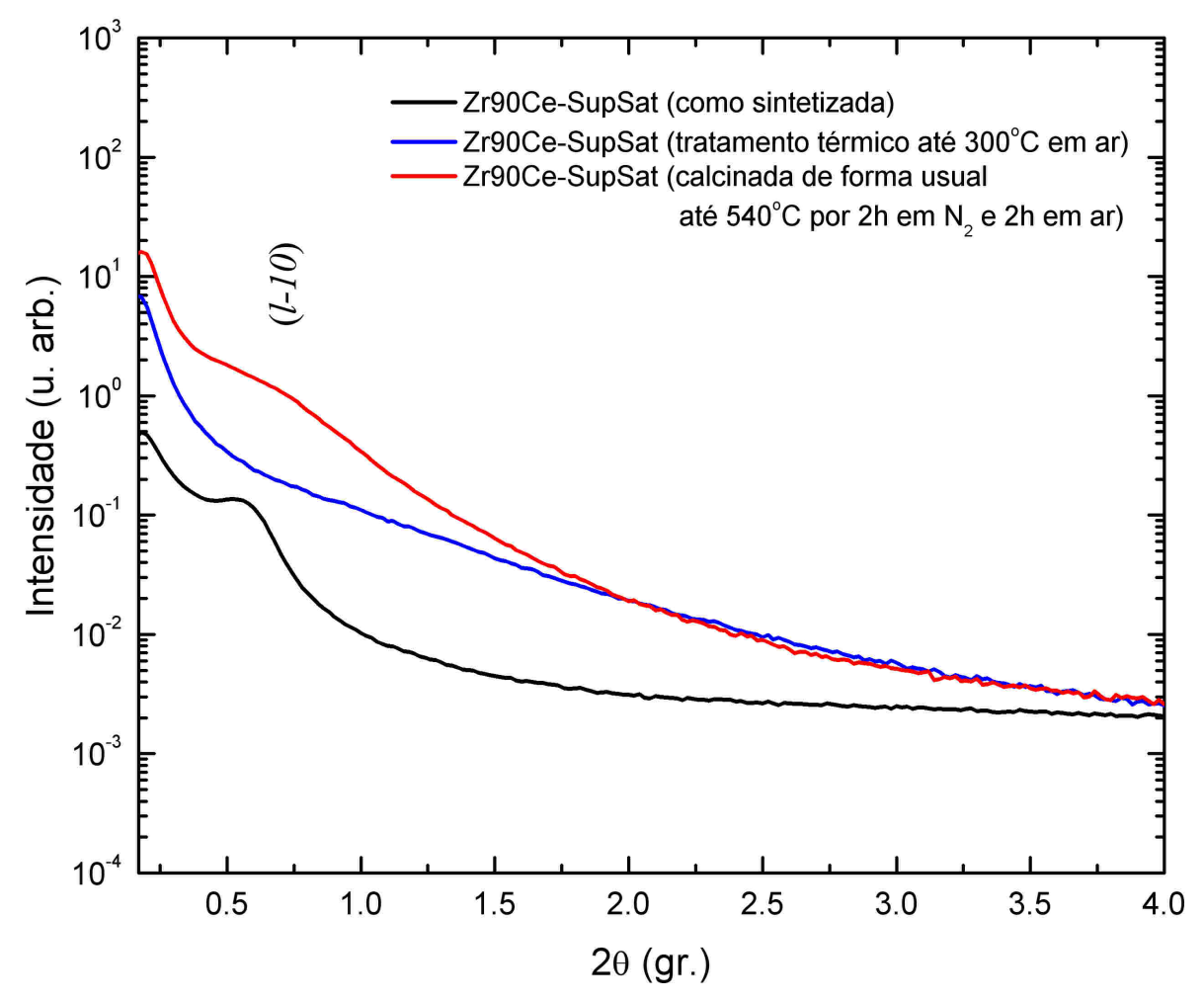

Figura 3.12: Resultados de SAXS para amostra como sintetizada, com tratamento térmico até $300^{\circ} \mathrm{C}$ e calcinada até $540^{\circ} \mathrm{C}$, de $\mathrm{ZrO}_{2} / \mathrm{CeO}_{2}$ com $90 \%$ de $\mathrm{CeO}_{2}$ (método solução supersaturada). 


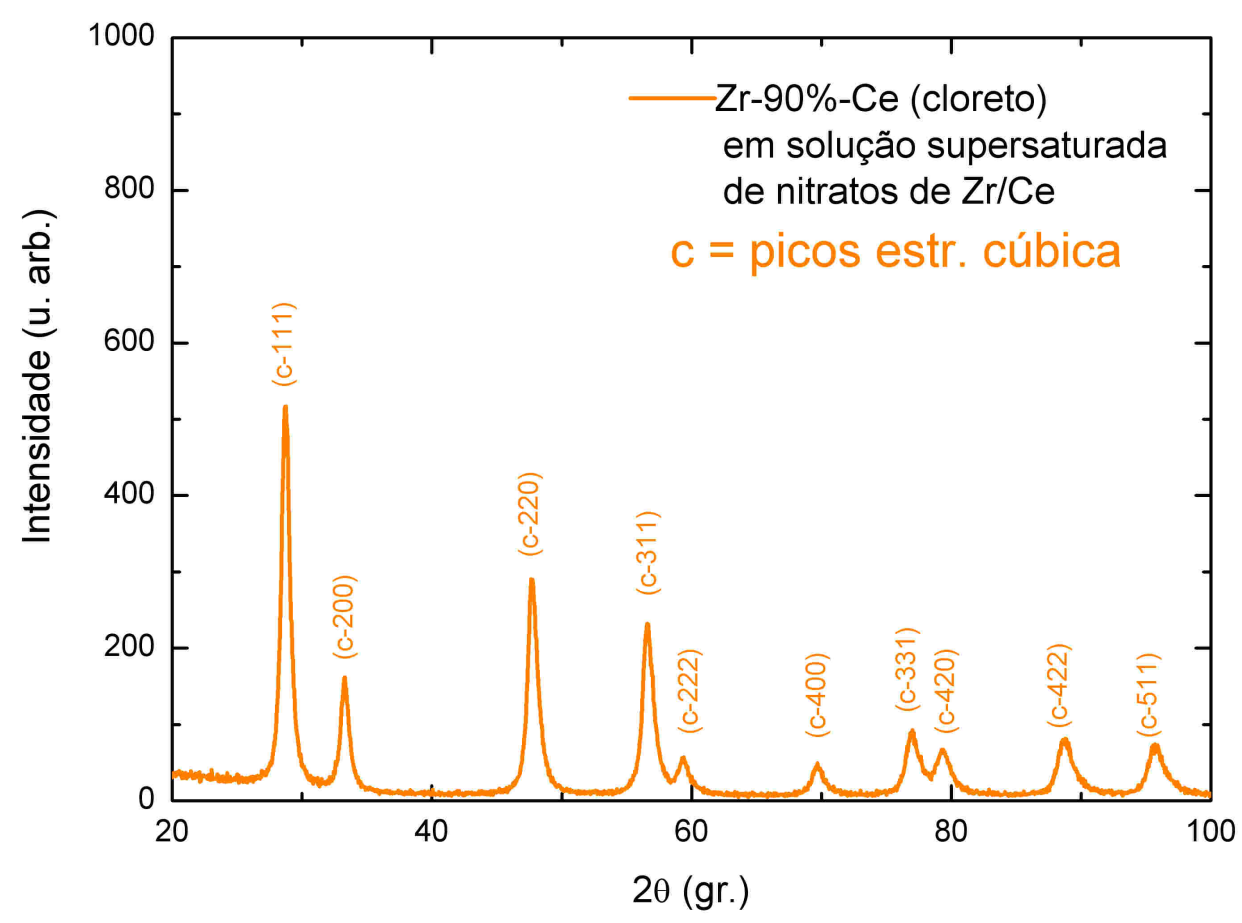

Figura 3.13: Resultados de XRD para amostra, calcinada até $540^{\circ} \mathrm{C}$, de $\mathrm{ZrO}_{2} / \mathrm{CeO}_{2}$ com $90 \%$ de $\mathrm{CeO}_{2}$ (método solução supersaturada).

Observa-se que há correlação entre os poros para a amostra calcinada de forma usual (fig. fig:sint) e que o tratamento térmico em ar destrói o ordenamento da estrutura, pois as reações com $\mathrm{O}_{2}$ liberam diretamente os produtos da queima sem decomposição. Dessa forma podemos descartar tratamentos térmicos em ar e constatar que paredes mais espessas, como esperado, podem contribuir para preservar o ordenamento estrutural após a remoção do molde.

O parâmetro de rede calculado para a reflexão $l-10$ (pois $\mathrm{A}_{l-20}=0$ ) da amostra AS é $\mathbf{a}=\mathbf{1 5}, \mathbf{8} \mathbf{n m}$, valor superior aos obtidos nas sínteses anteriores (tabela 3.6). Entretanto o valor de $\mathrm{f}_{\text {ord }}$ é inferior aos valores obtidos anteriormente.

Resultados de XRD mostraram que a amostra calcinada pelo método usual apresenta fase cristalina cúbica homogênea (fig. 3.13), pois essa amostra não apresenta o pico (112) da fase tetragonal. 
Tabela 3.6: Área das reflexões $l-10$ e $l-20\left(\mathrm{~A}_{l-10+l-20}\right)$, a área total sob os picos $\left(\mathrm{A}_{\text {total }}\right)$, a fração ordenada $\left(f_{o r d}\right)$ e o parâmetro de rede (a) para a amostra sintetizada pelo método solução supersaturada (AS).

\begin{tabular}{ccccc}
\hline Amostra & $\begin{array}{c}\mathbf{A}_{l-10+l-20} \\
\text { (u. arb. })\end{array}$ & $\begin{array}{c}\mathbf{A}_{\text {total }} \\
\text { (u. arb. })\end{array}$ & $\mathbf{f}_{\text {ord }}$ & $\begin{array}{c}\mathbf{a} \\
(\mathrm{nm})\end{array}$ \\
\hline Zr90CeSupSat & 6 & 36 & 0,17 & 15,8 \\
\hline
\end{tabular}

\subsection{Sínteses com silício: Resultados}

A estratégia de realizar dois métodos de síntese com Si teve como objetivo preparar estruturas mecanicamente mais rígidas, através de ligações Si-Zr, Si-Ce e obter maior área superficial após a remoção do molde. As concentrações de sílicio foram escolhidas de forma a não modificar drasticamente as propriedades de condução das amostras finais, para serem utilizadas nas aplicações citadas.

Um diagrama esquemático das sínteses com silício é apresentado na figura 3.14 . 


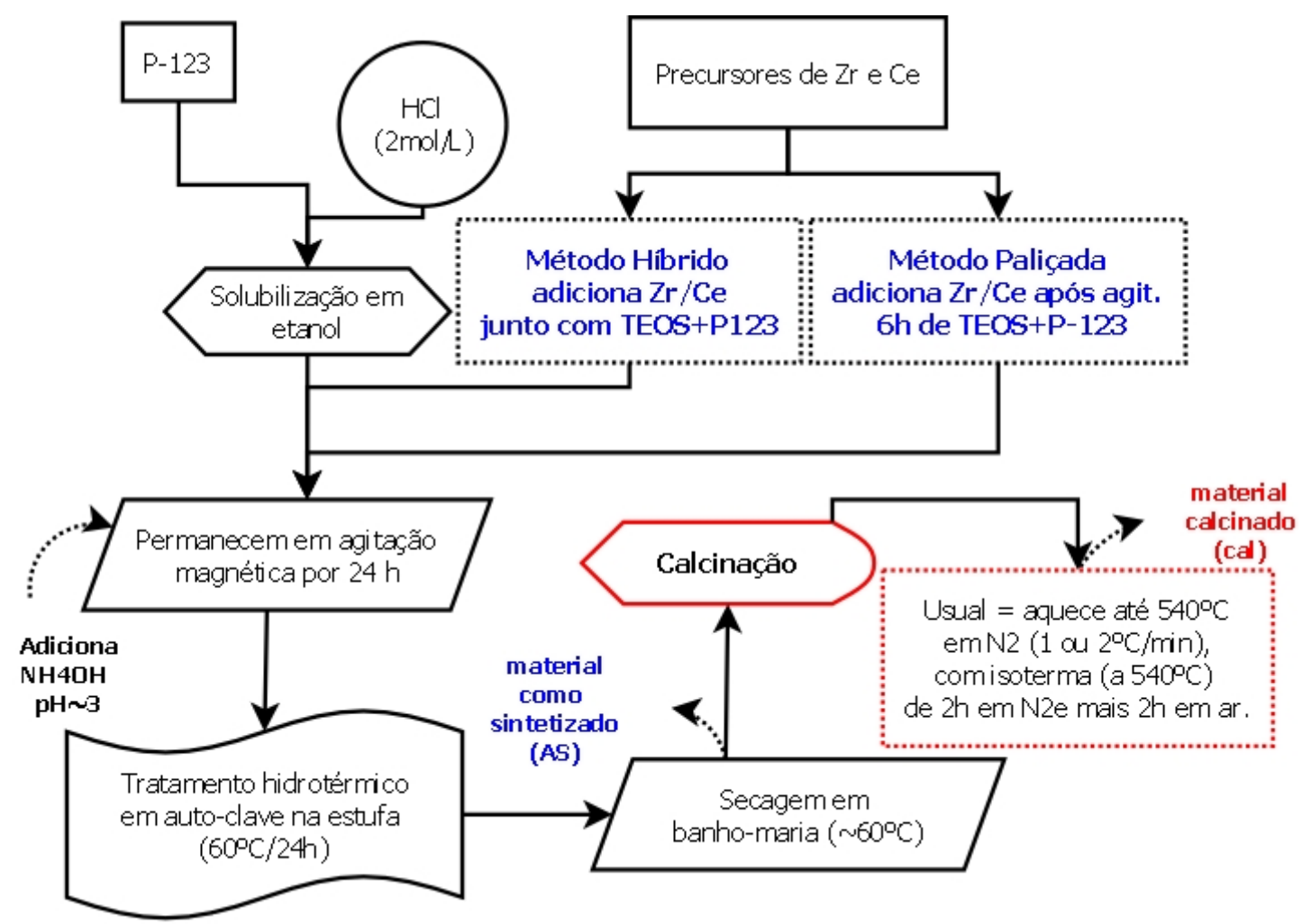

Figura 3.14: Diagrama esquemático das sínteses de $\mathrm{SiO}_{2}: \mathrm{ZrO}_{2}-\mathrm{CeO}_{2}$ poroso.

\subsubsection{Método híbrido}

Os resultados de SAXS para a amostra como sintetizada pelo método híbrido e calcinada encontram-se na figura 3.15 e o parâmetros de rede (a), a área total sob a curva $\left(\mathrm{A}_{\text {total }}\right)$, a área das reflexões $\left(\mathrm{A}_{l-10+l-20}\right)$ e a fração de poros ordenados $\left(\mathrm{f}_{\text {ord }}\right)$, encontram-se na tabela 3.7 .

Temos o aparecimento de duas reflexões da estrutura lamelar, $l-10$ e $l$-20, indicando um maior ordenamento do molde com sílica, zircônia e céria, comparado aos resultados anteriores. 


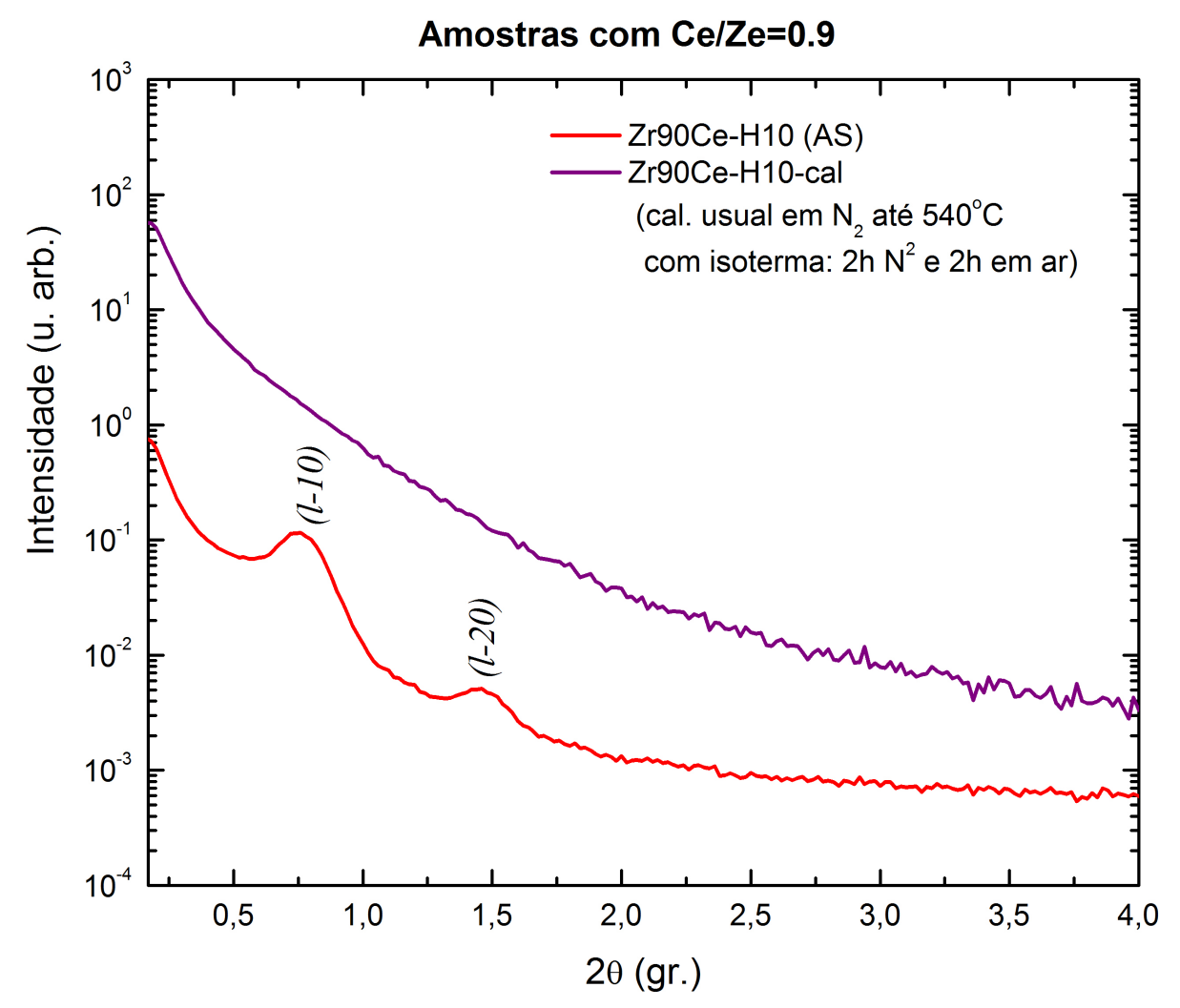

Figura 3.15: Resultados de SAXS para a amostra como sintetizada e calcinada (até $\left.540^{\circ} \mathrm{C}\right)$ para método híbrido $(0,1 \mathrm{~mol}$ de $\mathrm{Si})$.

Tabela 3.7: Área das reflexões $l-10$ e $l-20\left(\mathrm{~A}_{l-10+l-20}\right)$, a área total sob os picos $\left(\mathrm{A}_{\text {total }}\right)$, a fração ordenada $\left(f_{o r d}\right)$ e o parâmetro de rede (a) para a amostra sintetizada pelo método híbrido de $\mathrm{Si}(\mathrm{AS})$.

\begin{tabular}{ccccc}
\hline Amostra & $\begin{array}{c}\mathbf{A}_{l-10+l-20} \\
\text { (u. arb. })\end{array}$ & $\begin{array}{c}\mathbf{A}_{\text {total }} \\
\text { (u. arb. })\end{array}$ & $\mathbf{f}_{\text {ord }}$ & $\begin{array}{c}\mathbf{a} \\
(\mathrm{nm})\end{array}$ \\
\hline Zr90CeH10 & 14 & 38 & 0,37 & $11,82(8)$ \\
\hline
\end{tabular}

A amostra foi calcinada de forma usual até $540^{\circ} \mathrm{C}$ (de acordo com o esquema 3.14). Após a calcinação o ordenamento lamelar colapsa, como previsto, mas o sistema con- 
tinua apresentando porosidade.

A isoterma de adsorção-dessorção de $\mathrm{N}_{2}$ para a amostra sintetizada com silício pelo método híbrido encontra-se na figura 3.16, juntamente com a área superficial BET.

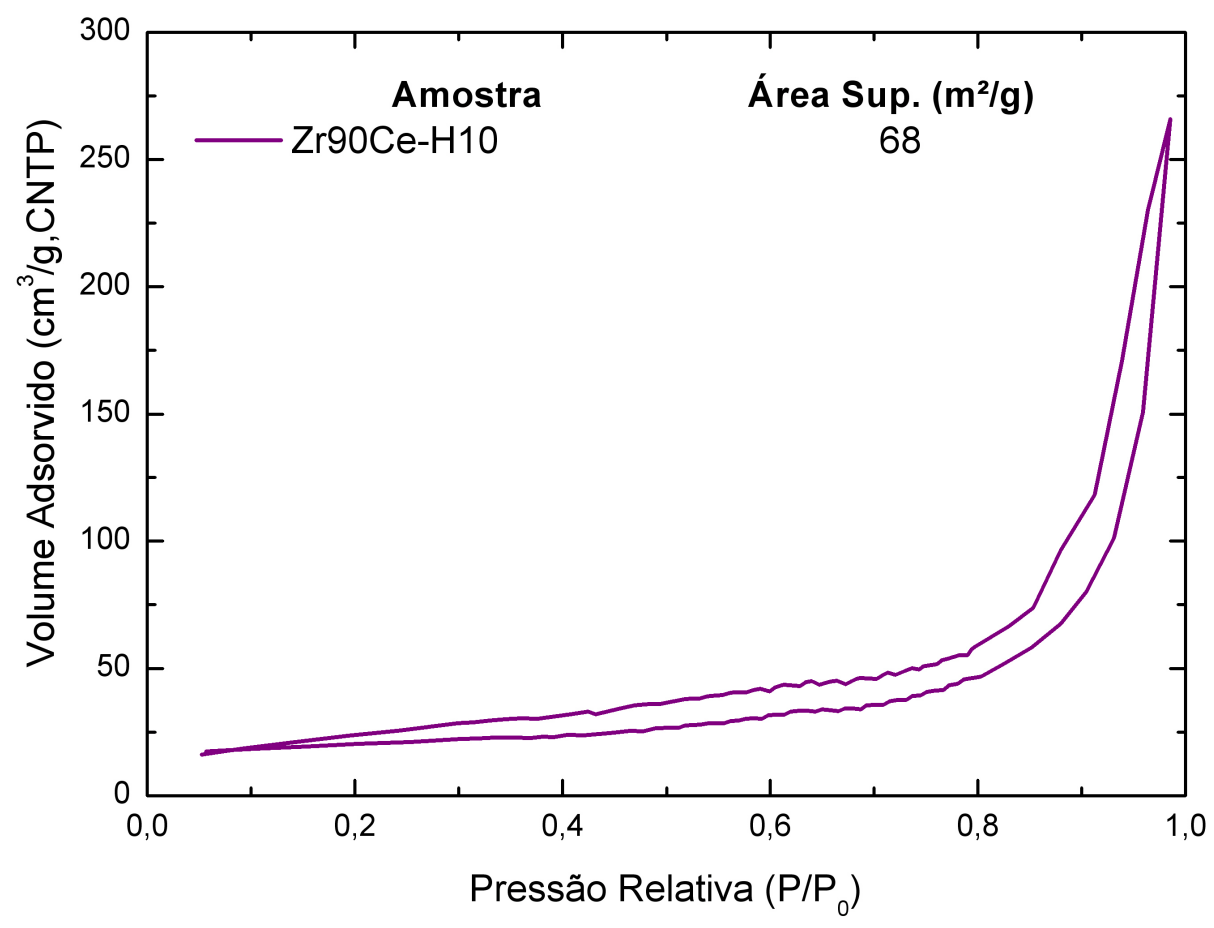

Figura 3.16: Resultados para a isoterma de adsorção-dessorção de $\mathrm{N}_{2}$ para a amostra com concentração molar de $90 \%$ de $\mathrm{CeO}_{2}$ e 0,1mol de $\mathrm{Si}$ (método híbrido).

A isoterma é do tipo $\mathrm{H}_{3}$, com poros pequenos e de formato de fenda regulares e é típica de uma distribuição não estreita de diâmetro de poros. A área superficial para a amostra Zr90Ce-H10, de $68 \mathrm{~m}^{2} / \mathrm{g}$, assim como o volume total adsorvido é maior que os valores obtidos das sínteses anteriores utilizadas nesse trabalho, demonstrando a eficácia da síntese com silício para produzir maiores áreas superficiais.

Os resultados da análise pelo método BJH também mostraram uma distribuição de diâmetros de poros com valores dispersos, portanto foi impossível atribuir um diâmetro médio de poros a essa amostra. 


\subsubsection{Método paliçada de Si}

Nesse método, foram formadas paredes contendo silício em torno do polímero antes da adição dos precursores de Zr e Ce (90\% de Ce) para sustentar mecanicamente a fase de zircônica-céria durante a remoção do molde.

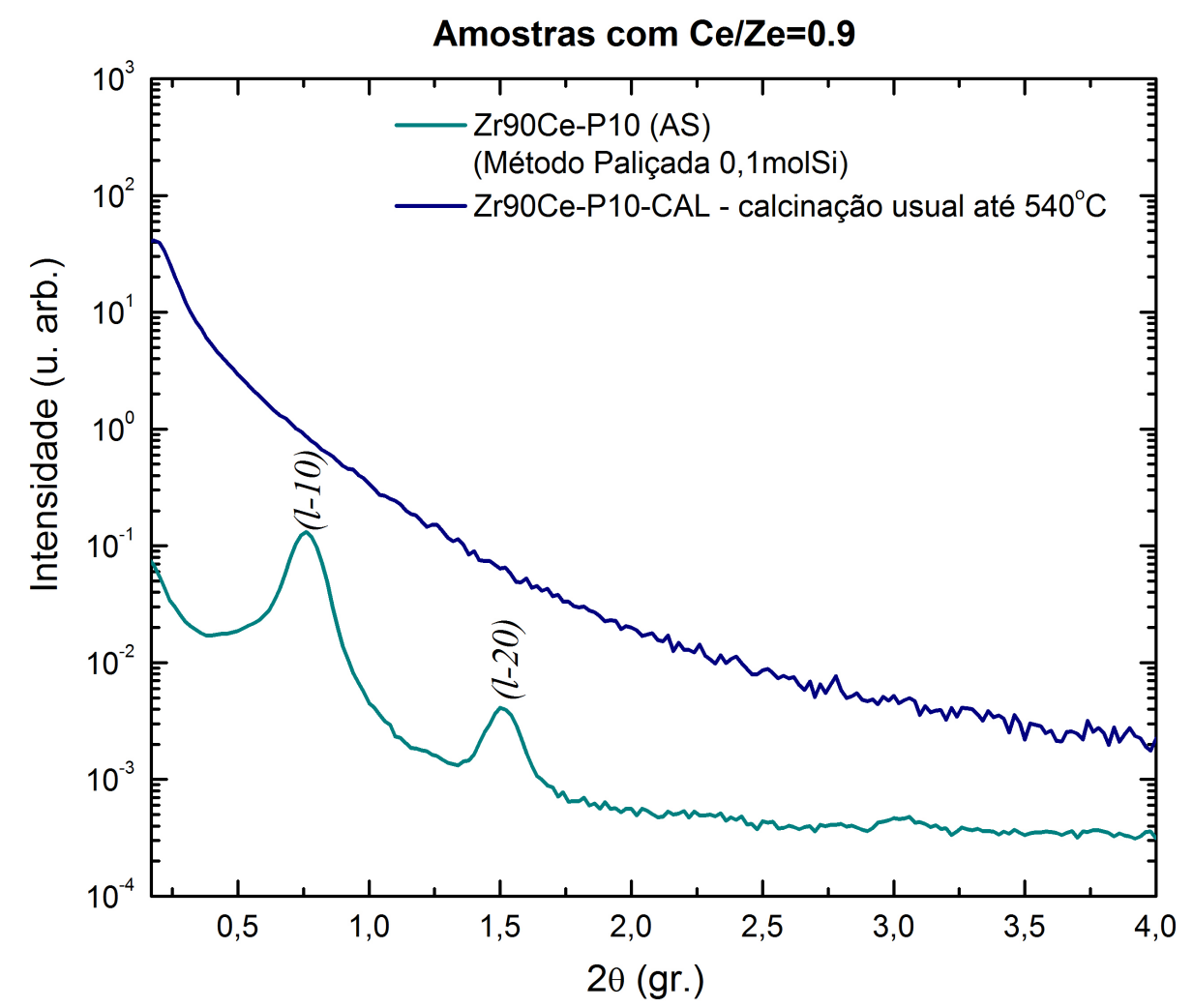

Figura 3.17: Resultados de SAXS para amostra como sintetizada e calcinada (até $540^{\circ} \mathrm{C}$ ) para amostra de $\mathrm{ZrO}_{2} / \mathrm{CeO}_{2}$ com $90 \%$ de $\mathrm{CeO}_{2}$ e 0,1 mol de $\mathrm{Si}$ (método paliçada).

Os resultados de SAXS para o método paliçada encontram-se nas figuras 3.17 e 3.18 . Como pode ser esperado, a introdução de $10 \mathrm{~mol} \%$ de Si promove um ordenamento estrutural melhor, o que pode ser avaliado pela área sob as reflexões $l-10$ e $l$-20 das amostras como sintetizadas (tabela 3.8). Para ambas concentrações de Si, o processo de calcinação até $540^{\circ} \mathrm{C}$ também destrói a estrutura ordenada lamelar, deixando o material poroso, com fendas entre as paredes inorgânicas. 
Tabela 3.8: Área das reflexões $l-10$ e $l-20\left(\mathrm{~A}_{l-10+l-20}\right)$, a área total sob os picos $\left(\mathrm{A}_{\text {total }}\right)$, a fração ordenada $\left(\mathrm{f}_{\text {ord }}\right)$ e o parâmetro de rede (a) para as amostras sintetizadas pelo método paliçada de Si (AS).

\begin{tabular}{ccccc}
\hline Amostras & $\begin{array}{c}\mathbf{A}_{l-10+l-20} \\
\text { (u. arb. })\end{array}$ & $\begin{array}{c}\mathbf{A}_{\text {total }} \\
\text { (u. arb. })\end{array}$ & $\mathbf{f}_{\text {ord }}$ & $\begin{array}{c}\mathbf{a} \\
(\mathrm{nm})\end{array}$ \\
\hline Zr90CeP10 & 22 & 42 & 0,52 & $11,70(1)$ \\
Zr90CeP30 & 69 & 275 & 0,25 & 14,7 \\
\hline
\end{tabular}

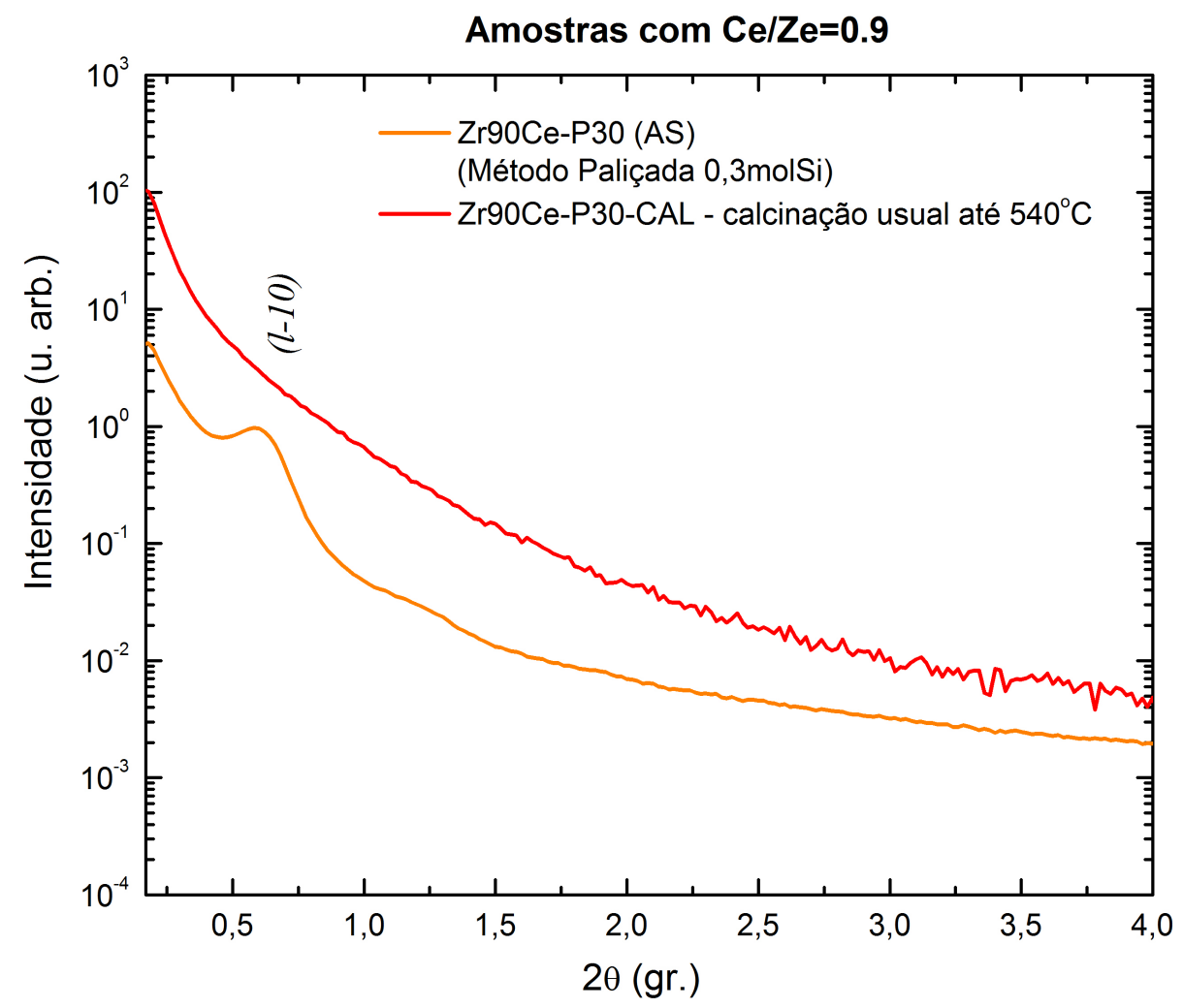

Figura 3.18: Resultados de SAXS para a amostra como sintetizada e calcinada (até $540^{\circ} \mathrm{C}$ ) para amostra de $\mathrm{ZrO}_{2} / \mathrm{CeO}_{2}$ com $90 \%$ de $\mathrm{CeO}_{2}$ e 0,3 mol de $\mathrm{Si}$ (método paliçada). 
De acordo com a tabela 3.8, há maior agregação dos precursores metálicos ao polímero com $30 \%$ de Si (maior $\mathrm{A}_{\text {total }}$ ). Por outro lado, uma maior fração ordenada foi obtida para menor conteúdo de Si $(10 \%)$.

\subsubsection{Estudo de SAXS/XRD da calcinação em várias temperaturas}

As propriedades estruturais das amostras de 0,1 e 0,3mol de Si do método paliçada foram analisadas como função da temperatura por SAXS/XRD ex-situ. A calcinação foi feita em $\mathrm{N}_{2}$ para 300,350 e $400^{\circ} \mathrm{C}$ a $1^{\circ} \mathrm{C} / \mathrm{min}$. Também foi feita a calcinação usual até $540^{\circ} \mathrm{C}$. Para cada temperatura foram feitas medidas de SAXS e XRD.

Os resultados para a síntese com 0,1mol de Si encontram-se nas figuras $3.19(\mathrm{a})$ e $3.19(\mathrm{~b})$. E, os resultados para 0,3mol encontram-se nas figuras $3.20(\mathrm{a}) \mathrm{e} 3.20(\mathrm{~b})$. 


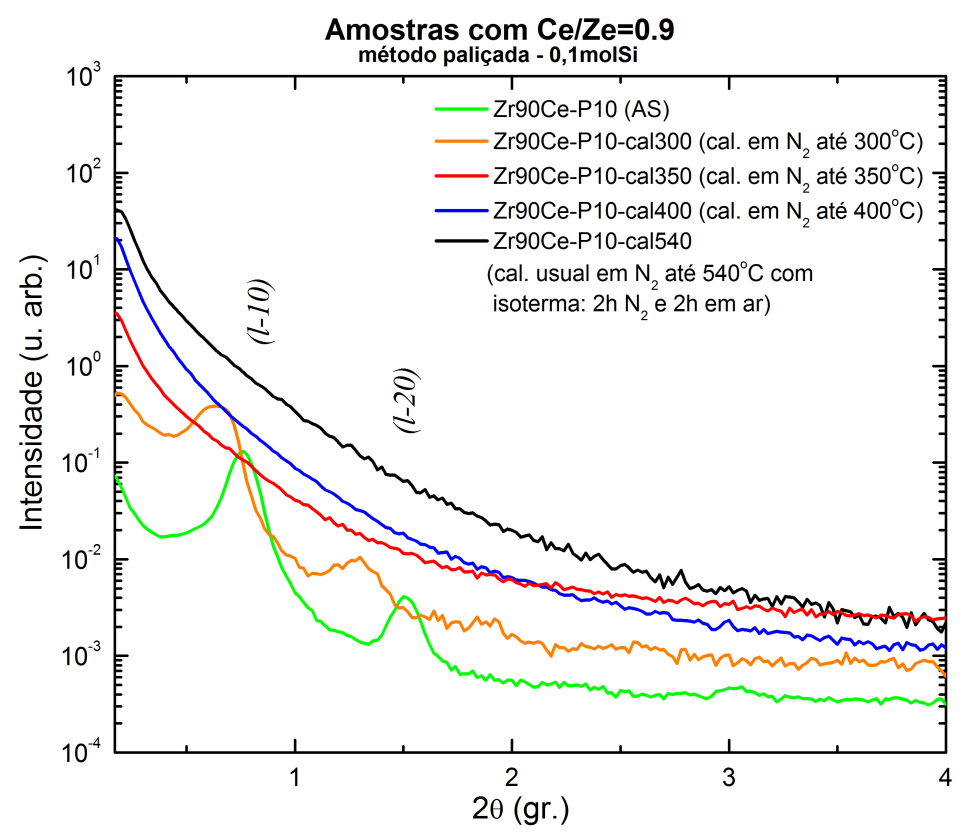

(a) Resultados de SAXS para amostra Zr90CeP10 como sintetizada e calcinada em várias temperaturas.

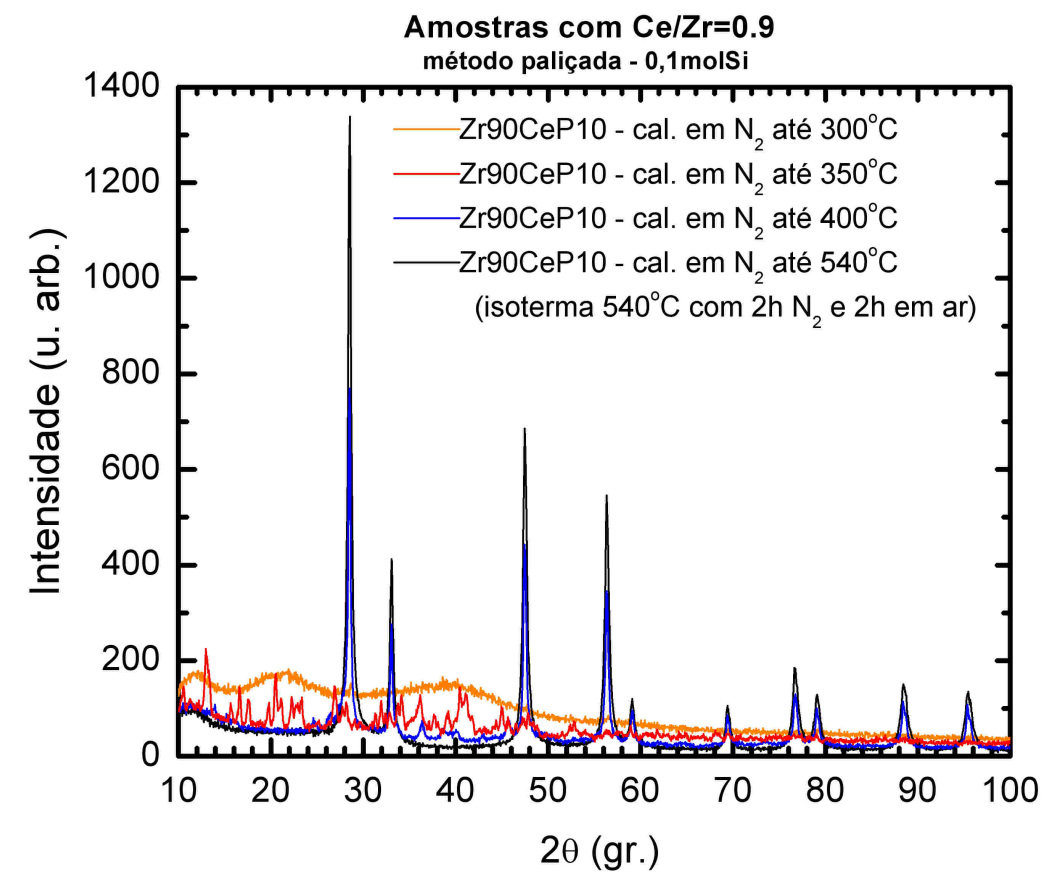

(b) Resultados de XRD para a amostra Zr90CeP10 calcinada em várias temperaturas.

Figura 3.19: Resultados de SAXS e XRD para tratamento térmico a 300, 350, 400 e calcinação até $540^{\circ} \mathrm{C}$ da amostra $\mathrm{Zr} 90 \mathrm{CeP} 10$, sintetizada através do método paliçada, com $90 \%$ de Ce e $10 \%$ de Si. 


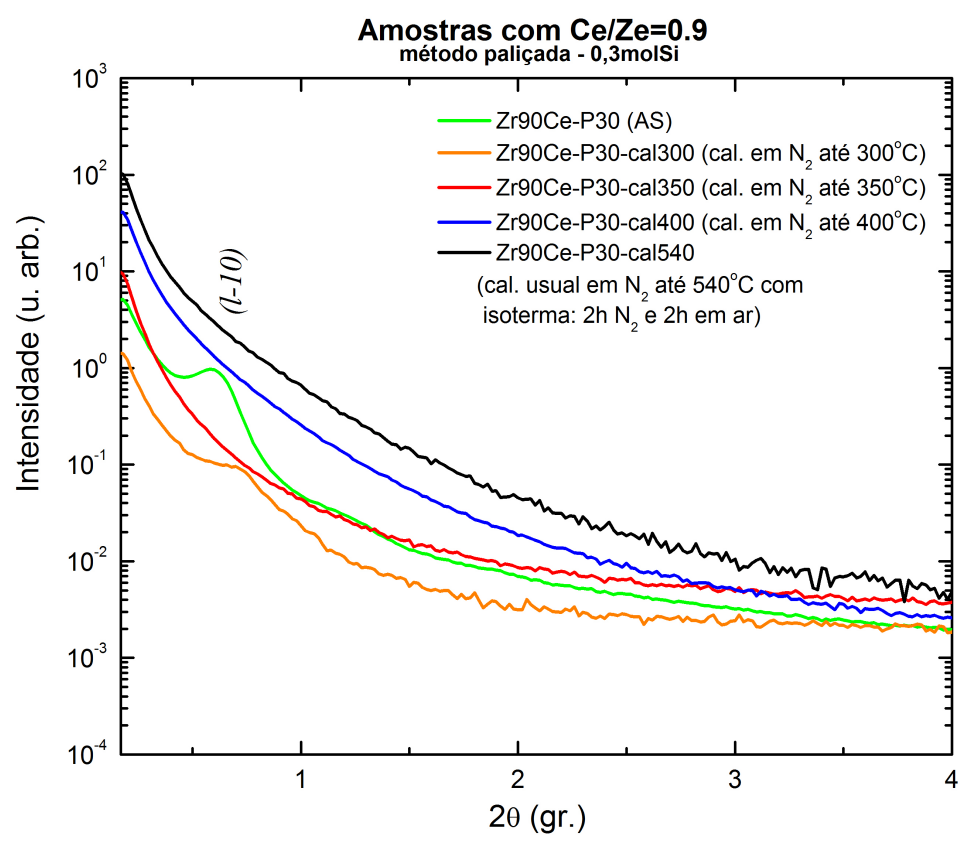

(a) Resultados de SAXS para amostra Zr90CeP30 como sintetizada e calcinada em várias temperaturas.

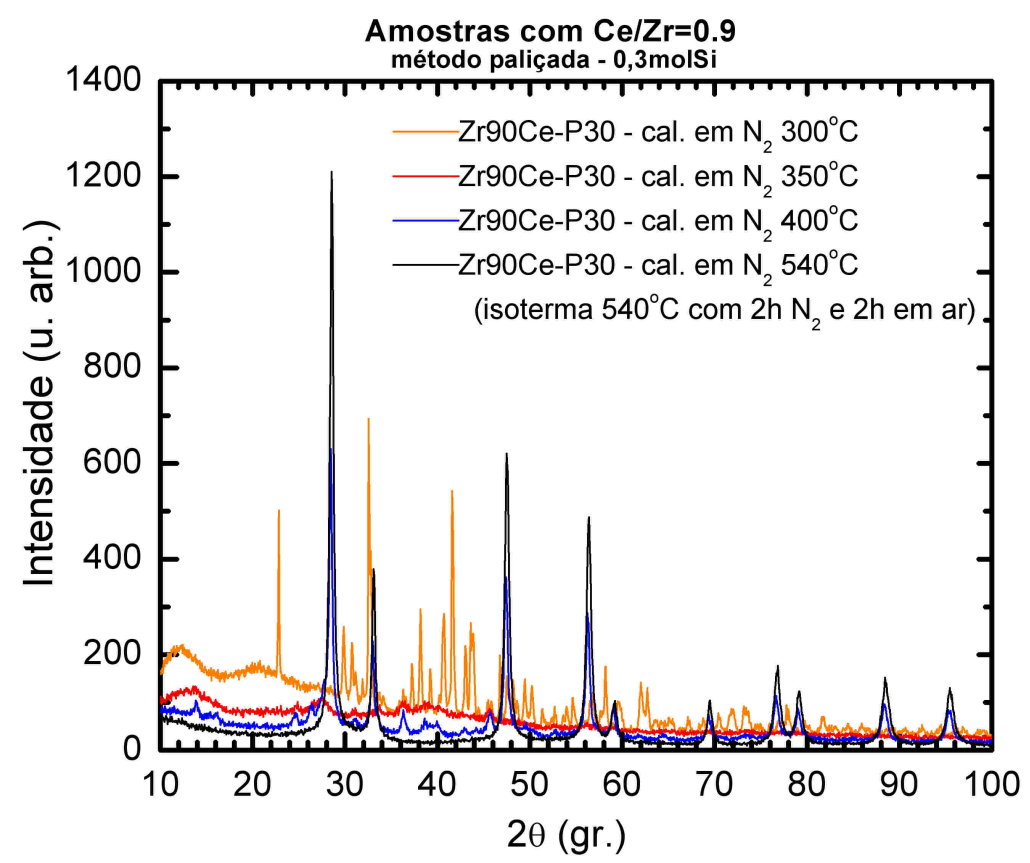

(b) Resultados de XRD para a amostra Zr90CeP30 calcinada em várias temperaturas.

Figura 3.20: Resultados de SAXS e XRD para tratamento térmico a 300, 350, 400 e calcinação até $540^{\circ} \mathrm{C}$ da amostra Zr90CeP30, sintetizada através do método paliçada, com $90 \%$ de Ce e $30 \%$ de Si. 
Através dos resultados de SAXS foram obtidos os parâmetros de rede (a) em função da temperatura, a área total $\left(\mathrm{A}_{\text {total }}\right)$, a área dos picos l-10 e l-20 $\left(\mathrm{A}_{l-10+l-20}\right)$ e a fração ordenada $\left(\mathrm{f}_{\text {ord }}\right)$, colocados na tabela 3.9 .

Tabela 3.9: Área das reflexões $l-10$ e $l-20\left(\mathrm{~A}_{l-10+l-20}\right)$, a área total sob os picos $\left(\mathrm{A}_{\text {total }}\right)$, a fração ordenada $\left(\mathrm{f}_{\text {ord }}\right)$ e o parâmetro de rede (a) para as amostras sintetizadas pelo método paliçada de Si em função da temperatura do tratamento térmico.

\begin{tabular}{ccccc}
\hline Amostras & $\begin{array}{c}\mathbf{A}_{l-10+l-20} \\
\text { (u. arb. })\end{array}$ & $\begin{array}{c}\mathbf{A}_{\text {total }} \\
\text { (u. arb. })\end{array}$ & $\mathbf{f}_{\text {ord }}$ & $\begin{array}{c}\text { a } \\
(\mathrm{nm})\end{array}$ \\
\hline Zr90CeP10 - AS & 22 & 42 & 0,52 & $11,70(1)$ \\
Zr90CeP10 em 300 $^{\circ} \mathbf{C}$ & 63 & 107 & 0,59 & $13,70(2)$ \\
Zr90CeP30 - AS & 69 & 275 & 0,25 & 14,7 \\
${\text { Zr90CeP30 } \mathbf{~ e m ~} \mathbf{3 0 0}^{\circ} \mathbf{C}}$ & 2 & 31 & 0,06 & 12,6 \\
\hline
\end{tabular}

Até $300^{\circ} \mathrm{C}$ as amostras apresentam ordenação de poros (figuras 3.19(a) e 3.20(a), mas ainda não há formação nas paredes do óxido de zircônia-céria com estrututura cúbica (figuras 3.19(b) e 3.20(b)]. Entre 300 e $350^{\circ} \mathrm{C}$ ocorre uma transformação de fase, com a possível formação das fases de $\mathrm{Zr}\left(\mathrm{ClO}_{4}\right)_{4}$ e $\mathrm{Ce}\left(\mathrm{ClO}_{4}\right)_{3}$. A $400^{\circ} \mathrm{C}$ observa-se a formação da $\mathrm{ZrO}_{2}-90 \% \mathrm{CeO}_{2}$ com estrutura $f c c$ e prováveis fases minoritárias policristalinas de $\mathrm{Zr}\left(\mathrm{ClO}_{4}\right)_{4}$ e $\mathrm{Ce}\left(\mathrm{ClO}_{4}\right)_{3}{ }^{*}$. Após a calcinação usual a $540^{\circ} \mathrm{C}$, somente a estrutura $f c c$ da $\mathrm{ZrO}_{2}-90 \% \mathrm{CeO}_{2}$ é observada.

Analisando os dados de SAXS e XRD, observa-se que o colapso final da estrutura lamelar ordenada, devido à decomposição do polímero, ocorre na mesma faixa de temperatura que a transformação do material de fase nanocristalina para policristalina.

As isotermas de adsorção-dessorção de $\mathrm{N}_{2}$ para amostras sintetizadas com silício pelo método paliçada $(0,1$ e $0,3 \mathrm{~mol}$ de $\mathrm{Si})$ encontram-se na figura 3.21 , juntamente com as respectivas áreas superficiais BET, de $73 \mathrm{~m}^{2} / \mathrm{g}$ para a amostra $\mathbf{Z r 9 0 C e - P 1 0}$ e, $128 \mathrm{~m}^{2} / \mathrm{g}$ para a amostra Zr90Ce-P30.

*Indexações realizadas no programa MDI Jade 6.5. 


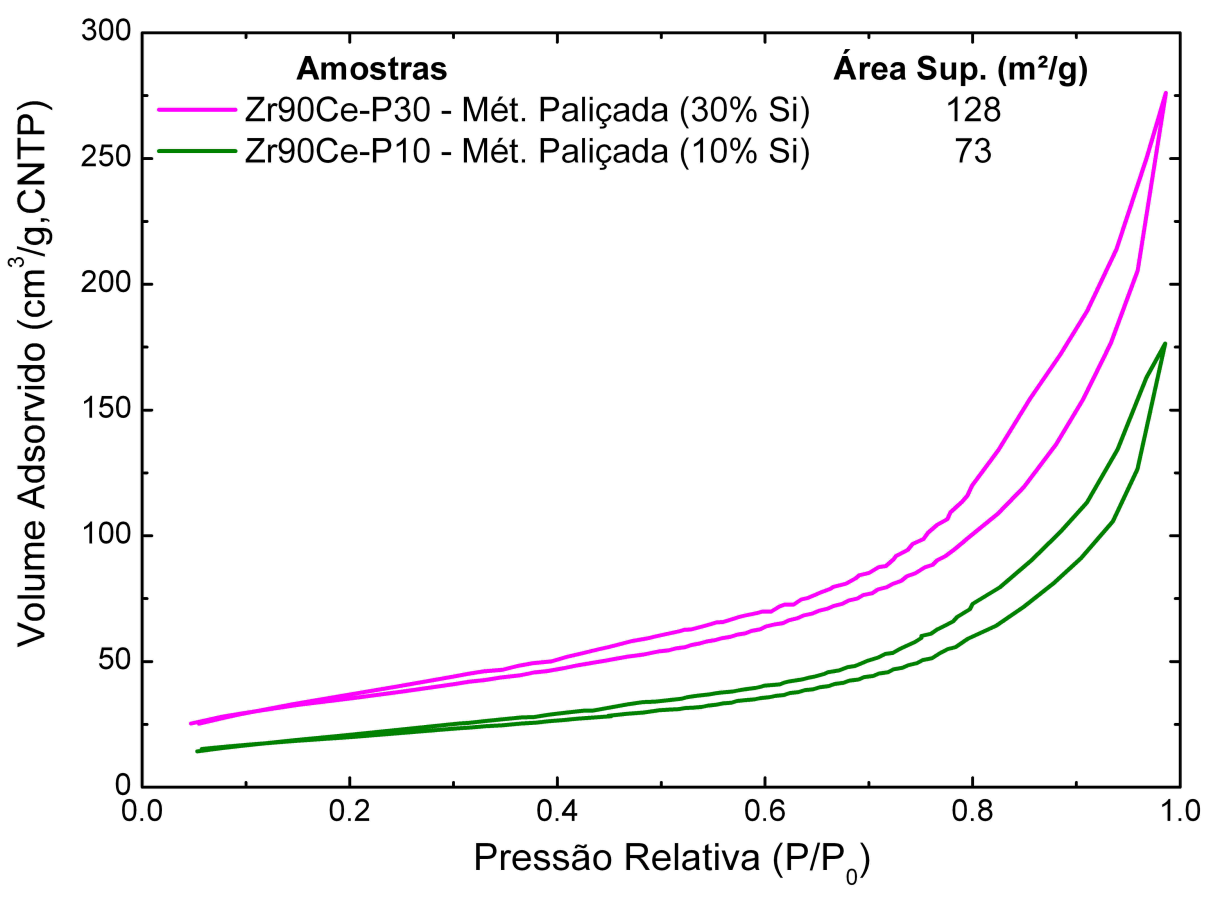

Figura 3.21: Resultados para as isotermas de adsorção-dessorção de $\mathrm{N}_{2}$ para as amostras com concentração molar de $90 \%$ de $\mathrm{CeO}_{2}, 0,3$ e 0,1mol de Si (método paliçada).

A amostra como sintetizada preparada com 0,3mol de Si apresenta $\mathrm{A}_{\text {total }}$ maior, mas uma estrutura menos organizada. Após a calcinação sua área superficial foi superior à da amostra com $0,1 \mathrm{~mol}$ de $\mathrm{Si}$, indicando a eficiência do processo de introdução de silício para aumentar a área superficial. O volume adsorvido é cerca de $\approx 1,6$ superior para $30 \%$ de Si. As isotermas para ambas amostras são do tipo $\mathrm{H}_{3}$, com poros pequenos em formato de fenda e sem morfologia de poros definidos da diferença entre as curvas de dessorção e adsorção.

Nesse caso, também os resultados da distribuição de tamanho de poros mostrou que essas amostras não possuem uma distribuição estreita de diâmetros e portanto o diâmetro médio de poros não foi calculado. 


\subsubsection{Método paliçada de Si com temperatura de síntese de $40^{\circ} \mathrm{C}$}

O método paliçada com temperatura de síntese superior foi testado com o objetivo de tentar agregar mais material às paredes durante a síntese. Foi preparada uma amostra com 0,3mol de Si e $90 \%$ de $\mathrm{CeO}_{2}$.

Os resultados de SAXS da amostra como sintetizada e calcinada pelo método descrito encontram-se na figura 3.22 .

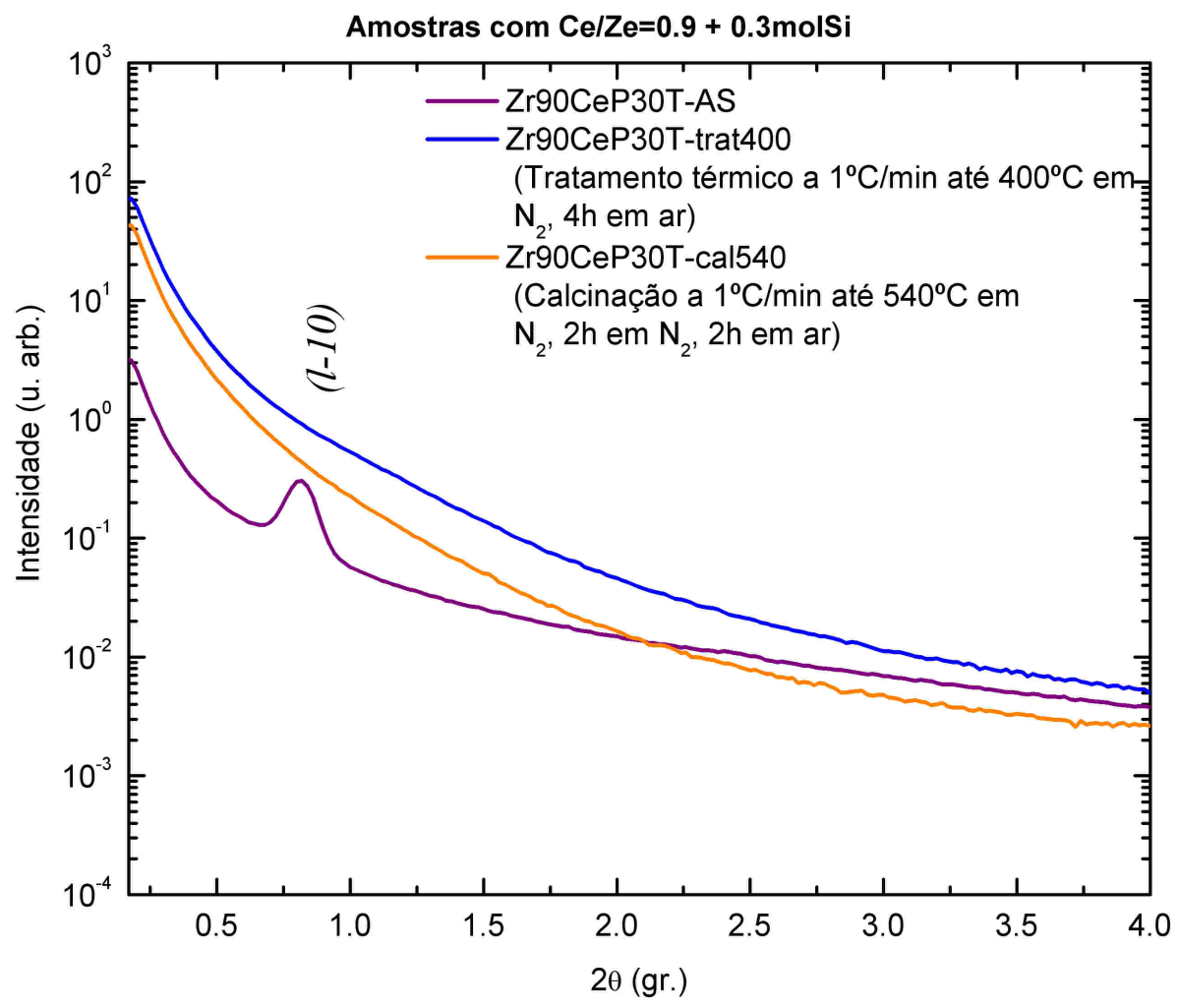

Figura 3.22: Resultados de SAXS para tratamento térmico a $400^{\circ} \mathrm{C}$ e calcinação até $540^{\circ} \mathrm{C}$ para o método paliçada temperatura de síntese de $40^{\circ} \mathrm{C}$, com $90 \%$ de Ce e $30 \%$ de Si.

A amostra como sintetizada apresentou apenas um pico de difração, referente à reflexão $l-10$ (em que $\mathrm{A}_{l-20}=0$ ) da fase lamelar, os parâmetros calculados da curva de SAXS são apresentados na tabela 3.10 . 


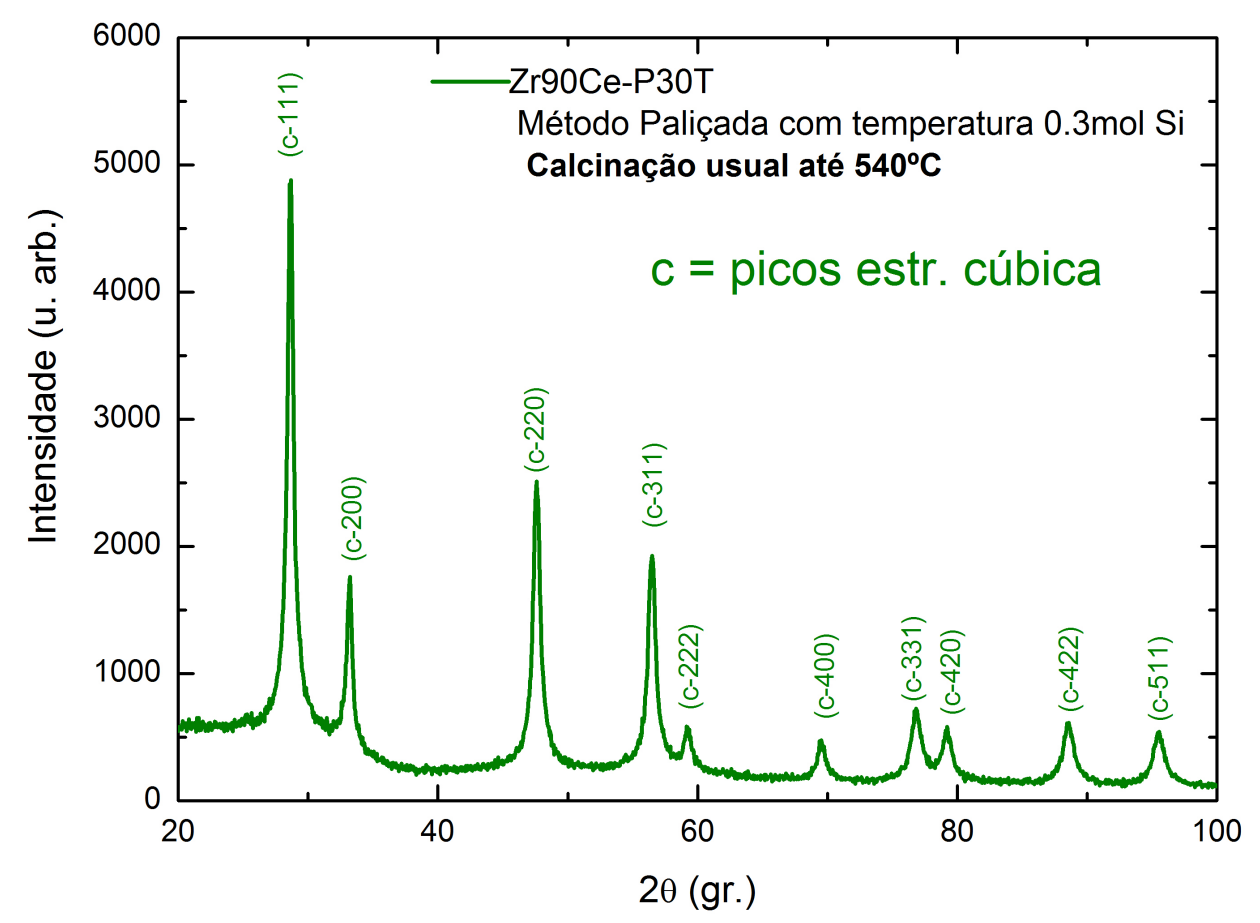

Figura 3.23: Resultados de XRD para amostra calcinada até $540^{\circ} \mathrm{C}$, de $\mathrm{ZrO}_{2} / \mathrm{CeO}_{2}$ com $90 \%$ de $\mathrm{CeO}_{2}$ (método paliçada com temperatura de síntese de $40^{\circ} \mathrm{C}$ ).

Tabela 3.10: Área das reflexões $l-10$ e $l$-20 $\left(\mathrm{A}_{l-10+l-20}\right)$, a área total sob os picos $\left(\mathrm{A}_{\text {total }}\right)$, a fração ordenada $\left(\mathrm{f}_{\text {ord }}\right)$ e o parâmetro de rede $(\mathrm{a})$ para a amostra sintetizada pelo método paliçada de Si com temperatura de síntese de $40^{\circ} \mathrm{C}(\mathrm{AS})$.

\begin{tabular}{ccccc}
\hline Amostra & $\begin{array}{c}\mathbf{A}_{l-10} \\
(\text { u. arb. })\end{array}$ & $\begin{array}{c}\mathbf{A}_{\text {total }} \\
(\text { u. arb. })\end{array}$ & $\mathbf{f}_{\text {ord }}$ & $\begin{array}{c}\mathbf{a} \\
(\mathrm{nm})\end{array}$ \\
\hline Zr90CeP30T & 25 & 61 & 0,42 & 10,8 \\
\hline
\end{tabular}

O processo de calcinação usual até $540^{\circ} \mathrm{C}$, bem como um tratamento térmico até $400^{\circ} \mathrm{C}$ em $\mathrm{N}_{2}$ (com isoterma de 4 horas em ar) destrói a ordenação do sistema lamelar.

A fração ordenada para essa amostra é 1,7 vezes maior que a da amostra sintetizada à temperatura ambiente (tabela 3.8), ou seja, o aumento da temperatura de síntese e tratamento hidrotérmico contribui para um melhor ordenamento estrutural. 
Em resumo, uma síntese ideal deve produzir um material com alta área superficial, paredes espessas de fase cristalina única e ordenamento de poros para favorecer o transporte mássico em aplicações catalíticas e SOFC's.

Nas sínteses descritas nesse trabalho, que serão comparadas a seguir, procura-se determinar parâmetros relevantes no processo de preparação do material que indicassem as condições mais favoráveis à obtenção das propriedades desejadas. 


\subsection{Fluxograma}

Um fluxograma de todos os métodos empregados durante esse trabalho pode ser visto na figura 3.24

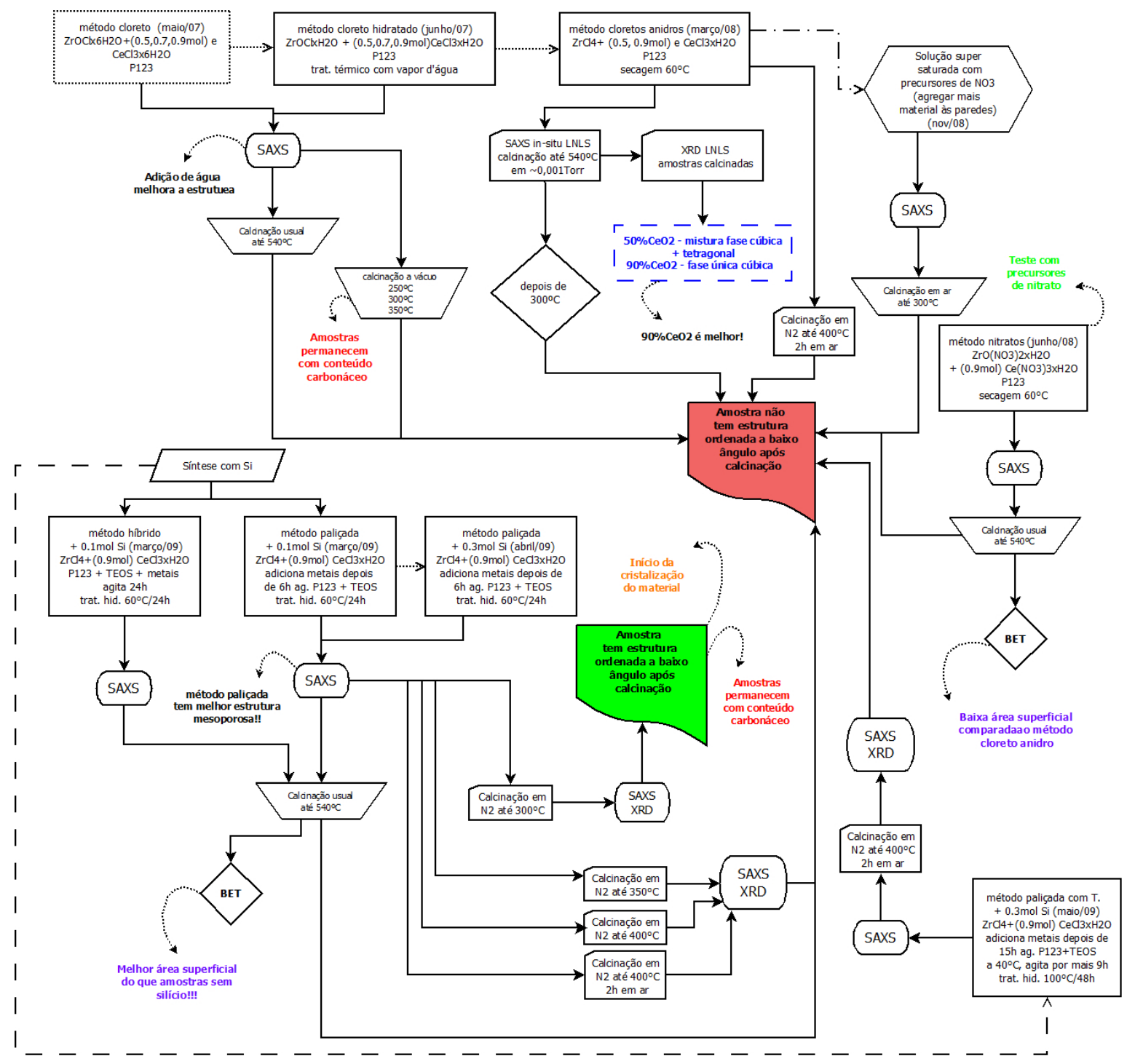

Figura 3.24: Fluxograma com estratégias de síntese, tratamentos térmicos e calcinações feitas nesse trabalho. 


\section{Capítulo 4}

\section{Comparação dos resultados e conclusões}

Na tabela 4.1 são apresentados também resultados obtidos para uma amostra nanocristalina de $\mathrm{ZrO}_{2}-50 \% \mathrm{CeO}_{2}$ (Zr50CenitG), preparada pelo método de gel-combustão, a título de comparação[37]. A amostra Zr50CeAN do presente estudo, mesmo sem apresentar estrutura de poros ordenada após a calcinação, possui área superficial $\approx 6$ vezes superior à do material preparado por gel-combustão. Esse resultado confirma a eficiência do processo de preparação de sistemas porosos via molde polimérico para o aumento da área superficial de materiais a base de zircônia [43, 44, 45]. Alguns desses trabalhos [43, 44] relatam a obtenção de $\mathrm{ZrO}_{2}-\mathrm{x} \% \mathrm{CeO}_{2}(20<\mathrm{x}<80)$ com estrutura mesoporosa ordenada de área superficial em torno de $100 \mathrm{~m}^{2} / \mathrm{g}$, mas com pequena fração ordenada, visto que se observa apenas um único pico largo de difração a baixo ângulo. Além disso, esses materiais possuem pequeno volume de poros, em torno de $0,2 \mathrm{~cm}^{3} / \mathrm{g}$, e com diâmetro pequeno, entre 3 e $4 \mathrm{~nm}$, comparado ao da SBA-15, cujo valor é em torno de 10nm. Nessas sínteses com Pluronic P-123 são utilizados menores conteúdos de molde, altas concentrações de álcool e nenhum ácido. Para $\mathrm{x}=20 \%$ as paredes são formadas pela fase policristalina tetragonal da zircônia, enquanto que para $\mathrm{x}>50 \%$ a fase cúbica é majoritária.

No trabalho aqui apresentado, os valores maiores de parâmetro de rede do material como sintetizado $(\mathrm{a} \approx 11 \mathrm{~nm})$, área superficial $\left(\approx 50-100 \mathrm{~m}^{2} / \mathrm{g}\right)$ e volume de poros $(0,2$ $0,4 \mathrm{~cm}^{3} / \mathrm{g}$ ) indicam que é possivel otimizar a síntese de $\mathrm{ZrO}_{2}-\mathrm{x} \% \mathrm{CeO}_{2}$, particularmente com sílica, para obter um sistema com melhores propriedades texturais e estruturais, comparadas às de outros autores [41, 42, 44, 43, 45].

O valores de área superficial (BET e BJH) e volume de poros obtidos neste trabalho dependem fundamentalmente do método de preparação do material poroso e independem da concentração nominal de $\mathrm{CeO}_{2}$ (amostras Zr50CeAN e Zr90CeAN).

Observa-se um aumento significativo da área superficial e do volume de poros a partir da introdução de sílica nesses sistemas. $\mathrm{O}$ valor da área total $\mathrm{A}_{\text {total }}$ dessas amostras 
Tabela 4.1: Comparação dos valores de área superficial $\left(\mathrm{S}_{i}\right)$ pelos métodos $\mathrm{i}=\mathrm{BET}$ e BJH, e volume de poros $\left(\mathrm{V}_{p}\right)$ determinado pelo método BJH, para todas as amostras analisadas. Comparação da área total $\left(\mathrm{A}_{\text {total }}\right)$ sob o pico das reflexões $l$-10 e l-20, a área do pico sem o fundo $\left(\mathrm{A}_{l-10+l-20}\right)$, o parâmetro de rede (a) e a fração ordenada $\left(\mathrm{f}_{\text {ord }}\right)$, de todas as amostras (AS) analisadas. As amosras identificadas com - não possuem estrutura de poros ordenada (*resultados obtidos no LNLS e normalizados para comparação com os resultados do Nanostar).

\begin{tabular}{|c|c|c|c|c|c|c|c|}
\hline Amostra & $\begin{array}{l}\mathbf{S}_{B E T} \\
\left(\mathrm{~m}^{2} / \mathrm{g}\right)\end{array}$ & $\begin{array}{l}\mathbf{S}_{B J H} \\
\left(\mathrm{~m}^{2} / \mathrm{g}\right)\end{array}$ & $\begin{array}{c}\mathbf{V}_{p} \\
\left(\mathrm{~cm}^{3} / \mathrm{g}\right)\end{array}$ & $\begin{array}{c}\mathbf{A}_{l-10+l-20} \\
\text { (u. arb.) }\end{array}$ & $\begin{array}{c}\mathbf{A}_{\text {total }} \\
(\text { u. arb. })\end{array}$ & $\mathbf{f}_{\text {ord }}$ & $\begin{array}{c}\mathbf{a} \\
(\mathrm{nm})\end{array}$ \\
\hline $\mathrm{Zr50Ce}$ & & & & 60 & 116 & 0,52 & $10,90(4)$ \\
\hline $\mathrm{Zr70Ce}$ & & & & 23 & 40 & 0,57 & $13,28(2)$ \\
\hline $\mathrm{Zr90Ce}$ & & & & 15 & 26 & 0,55 & $11,78(5)$ \\
\hline Zr50CeAN & 47 & 44 & 0,2 & $81^{*}$ & $115^{*}$ & $0,70^{*}$ & $14,1^{*}$ \\
\hline Zr90CeAN & 46 & 38 & 0,2 & $5^{*}$ & $18^{*}$ & $0,28^{*}$ & $12,7^{*}$ \\
\hline Zr90Cenit & 9 & 13 & 0,04 & - & - & - & - \\
\hline $\begin{array}{l}\text { Zr90Ce- } \\
\text { SupSat }\end{array}$ & & & & 6 & 36 & 0,17 & 15,8 \\
\hline Zr90CeH10 & 68 & 73 & 0,4 & 14 & 38 & 0,37 & $11,82(8)$ \\
\hline Zr90CeP10 & 73 & 65 & 0,3 & 22 & 42 & 0,52 & $11,70(1)$ \\
\hline Zr90CeP30 & 128 & 110 & 0,4 & 69 & 275 & 0,25 & 14,7 \\
\hline $\begin{array}{c}\mathrm{Zr90CeP10} \\
\left(\mathrm{cal} .300^{\circ} \mathrm{C}\right)\end{array}$ & & & & 63 & 107 & 0,59 & $13,70(2)$ \\
\hline $\begin{array}{l}\mathrm{Zr90CeP30} \\
\left(\text { cal. } 300^{\circ} \mathrm{C}\right)\end{array}$ & & & & 2 & 31 & 0,06 & 12,6 \\
\hline Zr90CeP30T & & & & 25 & 61 & 0,42 & 10,8 \\
\hline $\begin{array}{c}\text { Zr50CenitG } \\
\text { (gel-comb.) }\end{array}$ & 8 & 11 & 0,05 & - & - & - & - \\
\hline
\end{tabular}

apresenta correlação com as áreas superficiais obtidas. As amostras como sintetizadas (AS) que apresentaram um maior contraste de densidade eletrônica parede/polímero (maior $\mathrm{A}_{\text {total }}$ ) também apresentaram melhores propriedades morfológicas (maiores $\mathrm{S}_{B E T}$ e $\left.\mathrm{S}_{B J H}\right)$.

O aumento da concentração de céria nas amostras diminui o contraste de densidade eletrônica entre o polímero e as paredes, visto que há uma diminuição da intensidade de espalhamento total a baixos ângulos. Uma explicação para esse resultado é uma menor agregação das fases inorgânicas sobre o polímero, formando paredes mais finas. Por outro lado, o parâmetro de rede não apresenta uma variação sistemática com a 
concentração de céria.

Como já mencionado, a escolha da concentração de $90 \%$ de $\mathrm{CeO}_{2}$ para a elaboração dos diferentes métodos de síntese executados posteriormente baseou-se nos resultados obtidos no LNLS. A amostra Zr90CeAN apresentou paredes compostas por uma única fase cristalina $f c c$ e estabilidade estrutural maior durante o processo de calcinação, investigado por SAXS, quando comparada ao material com menor conteúdo de céria (Zr50CeAN). A síntese com precursores a base de cloreto anidro comparada à com precursores hidratados não resultou em amostras como sintetizadas (AS) com diferentes valores de $\mathrm{A}_{\text {total }}$, indicando que a concentração relativa dos precursores e do polímero é o fator principal que determina a agregação dos sais às micelas. Entretanto, diferentes precursores podem modificar a fração ordenada.

A amostra sintetizada pelo método de solução supersaturada apresentou maior valor para o parâmetro de rede $a$ em comparação com a amostra de partida (Zr90CeAN), mostrando que é possível aumentar a espessura das paredes, e que esse aumento é fundamental para a manutenção da estrutura ordenada após a calcinação usual em $\mathrm{N}_{2}$ e ar. O valor de $\mathrm{A}_{l-10+l-20}$ das amostras Zr90CeAN e Zr90CeSupsat como sintetizadas não se alterou, visto que a amostra Zr90CeSupsat foi formada a partir da primeira, mas a fração ordenada diminuiu. Esse resultado pode ser explicado a partir da formação de novas paredes inorgânicas sobre o excesso de polímero dissolvido em solução, dando origem a um material não ordenado. Após a calcinação da amostra Zr90CeSupsat em $\mathrm{N}_{2}$ e ar observou-se uma banda alargada, com máximo deslocado para ângulos maiores, indicando a presença de pequenas regiões porosas ordenadas, com poros de diâmetro inferior ao material AS, devido ao encolhimento da matriz no processo de remoção do molde[1, 10]. Em contrapartida, a calcinação em ar provocou a densificação do material, detectada pela diminuição do espalhamento a baixo ângulo, o que diminui o conteúdo de poros desordenados e também impede a formação de regiões porosas ordenadas.

As sínteses com adição de 10mol\% de silício (Zr90CeH10 e Zr90CeP10) deram origem a amostras com área total $\mathrm{A}_{\text {total }}$ muito similares, mas as diferenças na fração de ordenação indicam que há uma agregação cooperativa mais eficiente para agitação do P-123 e o TEOS antes da adição dos precursores a base de $\mathrm{Zr}$ e Ce.

As análises dos dados de SAXS das amostras Zr90CeP10 e Zr90CeP30 submetidas a tratamento térmico até $300^{\circ} \mathrm{C}$, temperatura na qual ainda existe uma pequena ordenação no material, mostraram um aumento não esperado no parâmetro de rede da amostra Zr90CeP10, uma vez que, durante a calcinação de amostras a base de silício 8] geralmente ocorre uma condensação das paredes, como observado para a amostra Zr90CeP30. O aumento do parâmetro de rede pode estar relacionado com a transição de fase nanocristalina para policristalina que ocorre em torno de $300^{\circ} \mathrm{C}$.

A adição de $30 \%$ de silício nessas amostras pode aumentar significativamente sua área superficial, mas essa quantidade deve ser analisada em relação à quantidade de zircônia e as propriedades de condução eletrônica das amostras sintetizadas. 
A síntese posterior, na qual variou-se a temperatura de síntese de $25^{\circ} \mathrm{C}$ (Zr90CeP30) para $40^{\circ} \mathrm{C}$ e o tempo de tratamento hidrotérmico de 24 horas a $60^{\circ} \mathrm{C}$, para 48 horas a $100^{\circ} \mathrm{C}(\mathrm{Zr} 90 \mathrm{CeP} 30 \mathrm{~T})$, gerou um material mais denso e com maior ordenação estrutural $\left(\mathrm{f}_{\text {ord }}\right)$.

O diagrama de fase da Zr e Ce com o Pluronic P-123 é desconhecido. Como a agregação é cooperativa, não necessariamente 2,0g de P-123 (como na síntese do SBA-15) fornece uma estrutura mesoporosa ordenada hexagonal bidimensional em compostos a base de zircônia e céria. Nesse trabalho foi obtida uma fase lamelar para esse conteúdo de polímero. Com o colapso da estrutura lamelar após a calcinação, há uma maior densificação das paredes, permitindo formar o composto $f c c$ poli ao invés de nanocristalino. Cálculos preliminares utilizando a fórmula de Scherrer 46] forneceram valores de tamanho de cristalito 4 vezes superiores aos materiais nanocristalinos crescidos por gel-combustão $(5-15 \mathrm{~nm})$ [28]. Paredes cristalinas, como em zeólitas, favorecem a interação com outros íons e moléculas em processos catalíticos[12].

Em resumo, pode-se concluir que o processo de preparação de materiais porosos a base de sílica pode ser estendido para a síntese de $\mathrm{ZrO}_{2}-90 \% \mathrm{CeO}_{2}$ porosa com paredes de fase cristalina $f c c$ homogênea, com área superficial e volume de poros maior que os materiais nanocristalinos preparados por outros métodos, particularmente quando sílica é adicionada à zircônia-céria. Além disso, concluiu-se que paredes mais espessas devem ser obtidas para preservar a estrutura de poros ordenados após a calcinação em atmosfera redutora, seguida de oxidação. 


\section{Capítulo 5}

\section{Trabalhos Futuros}

Como trabalhos futuros pretende-se:

- Analisar as curvas de SAXS obtidas através do programa GNOM[50] para a determinação das características morfológicas dos poros desordenados após o processo de calcinação e correlacioná-los com as medidas de NAI, feitas com maior precisão.

- Fazer o refinamento pelo método de Rietveld das curvas de XRD a fim de determinar o tamanho de cristalito e comparar os valores obtidos por outros métodos de síntese[28].

- Analisar por microscopia eletrônica de transmissão ou varredura a morfologia dos materiais calcinados.

- Utilizar a espectroscopia Raman para determinação das fases da zircônia-céria porosa[32].

- Análise através de RBS (Rutherford Back Scattering) para determinar as concentrações elementares das amostras sintetizadas.

- Utilizar a espectroscopia de impedância para avaliar as propriedades do material visando o seu uso como catalisador e em SOFC[51].

- Analisar por espectroscopia de absorção de raios X (XAS, EXAFS e XANES) a estrutura de ordem local ao redor do $\mathrm{Zr}[34$.

- Introduzir metais na estrutura visando aplicações catalíticas e SOFC[32, 35, 42].

- Investir na elaboração de uma síntese que produza o material mesoporoso ordenado após a calcinação. 
- Construir e analisar o diagrama de fase da $\mathrm{ZrO}_{2}-\mathrm{x} \% \mathrm{CeO}_{2}$ com P-123.

- Estabilizar a fase tetragonal da $\mathrm{ZrO}_{2}-\mathrm{x} \% \mathrm{CeO}_{2}$. 


\section{Referências Bibliográficas}

[1] V. Menyen, P. Cool, and E. F. Vasant, "Verified syntheses of mesoporous materials," Microporous and Mesoporous Materials 125 (2009) 170-233.

[2] A. Sayari and P. Liu, "Non-silica periodic mesostructured materials: recent progress," Microporous and Mesoporous Materials 12 (December, 1997) 149-177.

[3] S. Ruthstein, V. Frydman, and D. Goldfarb, "Study of the initial formation stages of the mesoporous material SBA-15 using spin-labeled block co-polymer templates," Journal of Physical Chemistry B 108 (2004) 9016-9022.

[4] A. F. Craievich, Small-angle X-ray scattering by nanostructured materials Handbook of Sol-Gel Science and Technology - Volume II: Materials characterization. Chapter 8. Kluwer Academic Publishers, 2005.

[5] E. L. Crepaldi, G. J. Soler-Illia, D. Grosso, A. B. Cagnol, and C. Sanchez, "Controlled formation of highly ordered cubic and hexagonal mesoporous nanocrystalline yttria-zirconia and ceria-zirconia thin films exhibiting high thermal stability," Angewandte Chemie 42 (2003) 347.

[6] K. S. W. Sing, D. H. Everett, R. A. W. Haul, L. Moscou, R. A. Pierotti, J. Rouquérol, and T. Siemieniewska, "Reporting physisorpion data for gas/solid systems with special reference to the determination of surface area and porosity," Pure 86 Applied Chemistry 57 (1985) 603.

[7] C. T. Kresge, M. E. Leonowicz, W. J. Roth, J. C. Vartuli, and J. S. Beck, "Ordered mesoporous molecular sieves synthesized by a liquid-crystaltemplate mechanism," Nature 359 (October, 1992) 710-712.

[8] U. Ciesla and F. Schüth, "Ordered mesoporous materials," Microporous and Mesoporous Materials 27 (1999) 131-149.

[9] J. S. Beck, J. C. Vartuli, W. J. Roth, M. E. Leonowicz, C. T. Kresge, K. D. Schmitt, C. T. W. Chu, D. H. Olson, and E. W. Sheppard, "A new family of mesoporous molecular sieves prepared with liquid crystal templates," Journal of the American Chemical Society 114 (December, 1992) 10834-10843. 
[10] C. Yu, Y. Yu, and D. Zhao, "Highly ordered large caged cubic mesoporous silica structures templated by triblock PEO-PBO-PEO copolymer," Chemical Communications (2000), no. 7, 575-576.

[11] A. Taguchi and F. Schüth, "Ordered mesoporous materials in catalysis," Microporous and Mesoporous Materials 77 (2005) 1-45.

[12] M. E. Davis, "Ordered porous materials for emerging applications," Nature 417 (June, 2002) 813-821.

[13] A. Corma, "From microporous to mesoporous molecular sieve materials and their use in catalysis," Chemical Reviews 97 (1997) 2373-2420.

[14] D. Zhao, J. Feng, Q. Huo, N. Melosh, G. H. Fredrickson, B. F. Chmelka, and G. D. Stucky, "Triblock copolymer syntheses of mesoporous silica with periodic 50 to 300 A pores," Science 279 (January, 1998) 548-552.

[15] D. Zhao, Q. Huo, J. Feng, B. F. Chmelka, and G. D. Stucky, "Nonionic triblock and star diblock copolymer and oligomeric surfactant syntheses of highly ordered, hydrothermally stable, mesoporous silica structures," Journal of the American Chemical Society 120 (June, 1998) 6024-6036.

[16] J. S. Lettow, Y. J. Han, P. Schmidt-Winkel, P. Yang, D. Zhao, G. D. Stucky, and J. Y. Ying, "Hexagonal to mesocellular foam phase transition in polymer-templated mesoporous silicas," Langmuir 16 (2000) 8291.

[17] P. D. Yang, D. Y. Zhao, D. I. Margolese, B. F. Chmelka, and G. D. Stucky, "Block copolymer templating syntheses of mesoporous metal oxides with large ordering lengths and semicrystalline framework," Chemical Materials 11 (1999) 2813-2826.

[18] T. Brezesinski, M. Antonietti, M. Groenewolt, N. Pinna, and B. Smarsly, "The generation of mesostructured crystalline $\mathrm{CeO}_{2}, \mathrm{ZrO}_{2}$ and $\mathrm{CeO}_{2}-\mathrm{ZrO}_{2}$ films using evaporation-induced self-assembly," New Journal of Chemistry 29 (2005) $237-242$.

[19] F. Chen and M. Liu, "Preparation of mesoporous yttria-stabilized zirconia (YSZ) and YSZ-NiO using a triblock copolymer as surfactant," Journal of Materials Chemistry 10 (2000) 2603-2605.

[20] M. Mamak, N. Coobs, and G. Ozin, "Practical solid oxide fuel cells with anodes derived from self-assembled mesoporous-NiO-YSZ," Chemical Communications 20 (2002) 2300-2301. 
[21] M. Mamak, N. Coobs, and G. Ozin, "Self-assembling solid oxide fuel cell materials: Mesoporous yttria-zirconia and metal-yttria-zirconia solid solutions," Journal of the American Chemical Society 122 (2000) 8932-8939.

[22] M. Mamak, N. Coombs, and G. A. Ozin, "Mesoporous nickel-yttria-zirconia fuel cell materials," Chemical Materials 13 (2001) 3564-3570.

[23] T. Hibino, S. Wang, S. Kakimoto, and M. Sano, "One-chamber solid oxide fuel cell constructed from a YSZ electrolyte with a Ni anode and LSM cathode," Solid State Ionics 127 (2000) 89-98.

[24] T. Hibino, A. Hashimoto, T. Inoue, J. Tokuno, S. Yoshida, and M. Sano, "A low-operating-temperature solid oxide fuel cell in hydrocarbon-air mixtures," Science 288 (2000) 2031-2033.

[25] T. S. Martins, T. L. R. Hewer, and R. Freire, "Cério: Propriedades catalíticas, aplicações tecnológicas e ambientais," Química Nova 30 (2007) 2001-2006.

[26] D. G. Lamas, R. O. Fuentes, I. O. Fábregas, M. E. F. de Rapp, G. E. Lascalea, J. R. Casanova, N. E. W. de Reca, and A. F. Craievich, "Synchrotron X-ray diffraction study of the tetragonal-cubic phase boundary of nanocrystalline $\mathrm{ZrO}_{2}-\mathrm{CeO}_{2}$ synthesized by a gel-combustion process," Journal of Applied Crystallography 38 (2005) 867-873.

[27] G. E. Lascalea, D. G. Lamas, L. Perez, E. D. Cabanillas, and N. W. de Reca, "Synthesis of $\mathrm{ZrO}_{2}-15$ mol\% $\mathrm{CeO}_{2}$ nanopowders by a pH-controlled nitrate glycine process," Materials Letters 58 (2004) 2456-2460.

[28] D. G. Lamas, G. E. Lascalea, R. E. Juarez, E. Djurado, L. Perez, and N. E. W. Reca, "Metastable forms of the tetragonal phase in compositionally homogeneous, nanocrystalline zirconia-ceria powders synthesided by gel-combustion," Journal of Materials Chemistry 13 (2003) 904-910.

[29] D. G. Lamas and N. E. W. de Reca, "X-ray diffraction study of compositionally homogeneous, nanocrystalline yttria-doped zirconia powders," Journal of Materials Science $3 \mathbf{5}$ (2000) 5563-5567.

[30] M. Yashima, M. Kakihana, and M. Yoshimura, "Metastable-stable phase diagrams in the zirconia-containing systems utilized in solid-oxide fuel cell application," Solid State Ionics 86-88 (1996) 1131-1149.

[31] M. Yashima, S. Sasaki, M. Kakihana, Y. Yamaguchi, H. Arashi, and M. Yoshimura, "Oxygen-induced structural change of the tetragonal phase around the tetragonal-cubic phase boundary in $\mathrm{ZrO}_{2}-\mathrm{YO}_{1.5}$ solid solutions," Acta Crystallographica Section B 50 (Dec, 1994) 663-672. 
[32] M. Yashima, K. Ohtake, H. Arashi, M. Kakihana, and M. Yoshimura, "Determination of cubic-tetragonal phase boundary in $\mathrm{Zr}_{1-X} \mathrm{Y}_{X} \mathrm{O}_{2-X / 2}$ solid solutions by raman spectroscopy," Journal of Applied Physics 74 (1993), no. 12, 7603-7605.

[33] P. M. Abdala, D. G. Lamas, M. E. F. de Rapp, N. E. W. de Reca, A. F. Craievich, and M. C. A. Fantini, "Synchrotron X-ray powder diffraction study of the tetragonal-cubic phase transition in nanostructured $\mathrm{ZrO}-\mathrm{ScO}$ solid solutions," Powder Diffraction Journal 23 (2) (2008) s87-s90.

[34] I. O. Fábregas, D. G. Lamas, N. E. W. de Reca, M. C. A. Fantini, A. F. Craievich, and R. J. Prado, "Synchrotron X-ray powder diffraction and extended $\mathrm{X}$-ray absorption fine structure spectroscopy studies on nanocrystalline $\mathrm{ZrO}_{2}-\mathrm{CaO}$ solid solutions," Journal of Applied Crystallograpgy 41 (2008) 680-689.

[35] M. Rezaei, S. M. Alavi, S. Sahebdelfar, L. Xinmei, L. Qian, and Z. F. Yan, " $\mathrm{CO}_{2}-\mathrm{CH}_{4}$ reforming over nickel catalysts supported on mesoporous nanocrystalline zirconia with high surface area," Energy $\&$ Fuels 21 (2007) $581-589$.

[36] M. Rezaei, S. M. Alavi, S. Sahebdelfar, and Z. Yan, "Mesoporous nanocrystalline zirconia powders: A promising support for nickel catalyst in $\mathrm{CH}_{4}$ reforming with $\mathrm{CO}_{2}, "$ Materials Letters 61 (2007) 2628-2631.

[37] J. R. Casanova, I. O. Fábregas, D. G. Lamas, N. E. W. de Reca, G. E. Lascalea, R. Kempf, A. F. Craievich, and C. V. Santilli, "Structure of nanoporous zirconia-based powders synthesized by different gel-combustion routes," Journal of Applied Crystallography 40 (2006) s147-s152.

[38] R. Liu, Y. Shi, Y. Wan, Y. Meng, F. Zhang, D. Gu, Z. Chen, B. Tu, and D. Zhao, "Triconstituent co-assembly to ordered mesostructured polymer-silica and carbon-silica nanocomposites and large-pore mesoporous carbons with high surface areas," Journal of the American Chemical Society 128 (2006) 11652-11662.

[39] D. Terribile, A. Trovarelli, J. Lorca, C. Leitenburg, and G. Dolcetti, "The synthesis and characterization of mesoporous high-surface area ceria prepared using a hybrid organic/inorganic route," Journal of Catalysis 178 (1998) 299-308.

[40] D. M. Lyons, K. M. Ryan, and M. A. Morris, "Preparation of ordered mesoporous ceria with enhanced thermal stability," Journal of Materials Chemistry 12 (2002) 1207-1212. 
[41] C. Ho, J. C. Yu, X. Wang, S. Laib, and Y. Qiub, "Meso- and macro-porous $\mathrm{Pd} / \mathrm{Ce}_{x} \mathrm{Zr}_{1-x} \mathrm{O}_{2}$ as novel oxidation catalysts," Journal of Materials Chemistry 15 (2005) 2193-2201.

[42] M. P. Kapoor, A. Raj, and Y. Matsumura, "Methanol decomposition over palladium supported mesoporous $\mathrm{CeO}_{2}-\mathrm{ZrO}_{2}$ mixed oxides," Microporous and Mesoporous Materials 44-45 (2001) 565-572.

[43] Y. Quan, L.-L. Li, S.-L. Lu, Duan, H.-H. L. Zhen-Xing, Y.-X. Zhu, and C.-H. Yan, "Facile synthesis of Zr-based functional materials with highly ordered mesoporous structures," Journal of Physical Chemistry C 113 (2009) 4117-4124.

[44] Q. Yuan, Q. Liu, W.-G. Song, W. Feng, W.-L. Pu, L.-D. Sun, Y.-W. Zhang, and C.-H. Yan, "Ordered mesoporous $\mathrm{Ce}_{1-x} \mathrm{Zr}_{x} \mathrm{O}_{2}$ solid solutions with crystalline walls," Journal of the American Chemical Society 129 (2007) 6698-6699.

[45] H. Li, L. Zhang, H. Dai, and H. He, "Facile synthesis and unique physicochemical properties of three-dimensionally ordered macroporous magnesium oxide, gamma-alumina, and ceria-zirconia solid solutions with crystalline mesoporous walls.," Inorganic Chemistry 48 (2009) 4421-4433.

[46] B. D. Cullity and S. R. Stock, Elements of X-ray Diffraction. Prentice Hall, 2001.

[47] S. Brunauer, P. H. Emmet, and E. Teller, "Adsorption of gases in multimolecular layers," Journal of the American Chemical Society 60 (1938) 309-319.

[48] E. P. Barrett, L. G. Joyner, and P. P. Halenda, "The determination of pore volume and area distributions in porous substances. I. computations from nitrogen isotherms," Journal of the American Chemical Society 73 (January, 1951) $373-380$.

[49] R. I. Masel, Principles of Adsorption and Reaction on Solid Surfaces. John Wiley \& Sons Inc., 1996.

[50] D. I. Svergun, "Mathematical methods in small-angle scattering data analysis," Journal of Applied Crystallografy 24 (1991) 485-492.

[51] R. Mucillo, "Impedance spectroscopy analysis of zirconia: $8 \% \mathrm{~mol}$ yttria solid electrolytes with graphite pore former," Journal of Materials Research 24 (5) (2009) 1780-1784. 